
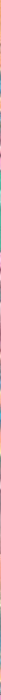

\title{
MÚLTIPLOS OLHARES SOBRE A FORMAC̄̃̃O DE PROFESSORES NO BRASIL
}

\section{MARIJÂNE SILVEIRA DA SILVA NEIDE BORGES PEDROSA ROGÉRIA MOREIRA REZENDE ISOBE [Orgs.]}

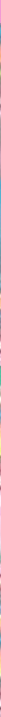




\section{MÚLTIPLOS OLHARES SOBRE A FORMAÇÃO DE PROFESSORES NO BRASIL}

Marijâne Silveira da Silva

Neide Borges Pedrosa

Rogéria Moreira Rezende Isobe

Organizadoras 
Reitor Ari Miguel Teixeira Ott

Vice-Reitor José Juliano Cedaro

EDITORA DA UNIVERSIDADE FEDERAL DE RONDÔNIA

$\begin{array}{ll} & \text { CONSELHO EDITORIAL } \\ \text { Presidente } & \text { Lou-Ann Kleppa } \\ & \text { Ariana Boaventura Pereira } \\ \text { Carlos Alexandre Trubiliano } & \text { Eliane Gemaque Gomes Barros } \\ & \text { Gean Carla Silva Sganderla } \\ \text { Leandro Soares Moreira Dill } & \text { Márcio Secco } \\ & \text { Marli Lúcia Tonatto Zibetti } \\ & \text { Pedro Ivo Silveira Andretta } \\ & \text { Ricardo Gilson da Costa Silva } \\ & \text { Xênia de Castro Barbosa }\end{array}$

Editora Filiada
Edufro - Editora da Universidade Federal de Rondônia BR 364, Km 9,5
Campus Unir
76801-059 - Porto Velho - RO
Tel.: (69) 2182-2175
www.edufro.unir.br edufro@unir.br




\section{MÚLTIPLOS OLHARES SOBRE A FORMAÇÃO DE PROFESSORES NO BRASIL}

Marijâne Silveira da Silva

Neide Borges Pedrosa

Rogéria Moreira Rezende Isobe

Organizadoras

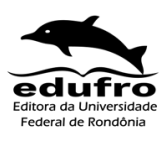

Porto Velho - RO 
(C) 2020 by Marijâne Silveira Da Silva, Neide Borges Pedrosa, Rogéria Moreira Rezende Isobe (Organizadoras)

Esta obra é publicada sob a Licença Creative Commons Atribuição-Não

Comercial 4.0 Internacional.

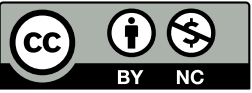

Capa:

Jôsy Monteiro Alves

Vitoria Gonçalves Morão

Revisão:

Dra. Jeane Mari Spera

Projeto gráfico:

Edufro - Editora da Universidade Federal de Rondônia

Diagramação:

Guilherme André de Campos

Impressão e acabamento:

Seike \& Monteiro Editora

Aprovado no Edital 02/2018/EDUFRO

Dados Internacionais de Catalogação na Publicação

Fundação Universidade Federal de Rondônia (UNIR)

Ficha Catalográfica elaborada pela Biblioteca Central da UNIR

F981 Fundação Universidade Federal de Rondônia.

Múltiplos olhares sobre a formação de professores no Brasil / organização Marijâne Silveira da Silva, Neide Borges Pedrosa, Rogéria Moreira Rezende Isobe. - Porto Velho, RO: EDUFRO, 2020.

186 p.; il.

ISBN: 978-65-87539-35-5 (físico)

ISBN: 978-65-87539-28-7 (digital)

1. Formação de professores no Brasil. 2. Práticas docentes. 3. Reflexões sobre a docência. 4. Formação continuada. I. Silva, Marijâne Silveira Da. II. Pedrosa, Neide Borges. III. Isobe, Rogéria Moreira Rezende. IV. Fundação Universidade Federal de Rondônia.

CDU 377.8(81) 


\section{Sumário}

7

APRESENTAÇÃO

15 1. "O PAPAGAIO E DESCARTES": UMA REFLEXÃO SOBRE A SUBJETIVIDADE NA FORMAÇÃO DE PROFESSORES DO IDIOMA ESTRANGEIRO

Miguel Nenevé

Lusinilda Carla Pinto Martins

33 2. APORTES TEÓRICOS PARA CONSTRUÇÃO DE UM CURRÍCULO RIZOMÁTICO NA FORMAÇÃO DE PROFESSORES

Fernanda Borges de Andrade

Valéria Moreira Rezende

45 3. FORMAÇÃO CONTINUADA NA EDUCAÇÃO INFANTIL E SUAS CONTRIBUIÇÕES PARA A CONSTRUÇÃO DA IDENTIDADE PROFISSIONAL

Andréa Rodrigues de Souza

José Carlos de Melo

65 4. A FORMAÇÃO DO PROFESSOR NO CONTEXTO DA INCLUSÃO

Elizabeth Regina Streisky de Farias

Leociléa Aparecida Vieira

81

5. TECNOLOGIAS EMERGENTES E FORMAÇÃO DE PROFESSORES: O QUE AS GRADES CURRICULARES DE CURSOS DE PEDAGOGA SINALIZAM?

Rafael Fonseca de Castro

97 6. A FORMAÇÃO DE PROFESSORES DA EDUCAÇÃO PROFISSIONAL: DESAFIOS E POSSIBILIDADES

Jacqueline Oliveira Lima Zago 
113 7. FORMAÇÃO CONTINUADA DE PROFESSORES E RELAÇÕES ÉTNICO RACIAIS: QUESTÕES SOBRE A TEMÁTICA INDÍGENA NAS ESCOLAS

Rogéria Moreira Rezende Isobe Neide Borges Pedrosa

127 8. POLÍTICAS DE FORMAÇÃO INICIAL DE PROFESSORES: EXPERIÊNCIAS DO PIBID E A PRÁXIS DOCENTE Leonice Matilde Richter Maria Célia Borges

141 9. NATURALIZAÇÃO DO ESTÁGIO E INVISIBILIDADE DO TRABALHO (DO ESTÁGIO CURRICULAR OBRIGATÓRIO): UMA TESE EM CONSTRUÇÃO

Valdeniza Maria Lopes da Barra

159 10. LETRAMENTOS DIGITAIS E FORMAÇÃO INICIAL DE PROFESSORES PARA A EDUCAÇÃO ONLINE

Terezinha Fernandes Martins de Souza

181 Sobre os autores 


\section{APRESENTAÇÃO}

Formação. Forma-ação. Ação de formar. Ações que formam. Colocar numa fôrma? Enformar? Reformar? Dar forma? Ações de um sobre o outro e sobre si mesmo/a. Formação docente: ação de formar um sujeito docente. De que modos formamos e nos formamos? Que formação? ${ }^{1}$

Para introduzir o debate sobre a formação de professores, fio condutor deste livro, será preciso, antes de mais nada, situá-lo a partir de nossa vivência como docentes, nos cursos de licenciatura, com todas as incertezas, paradoxos, lacunas, im/possibilidades, dilemas e mistérios que envolvem a prática do magistério. Nós que nos dedicamos à formação de educadores experimentamos em nosso cotidiano a natureza complexa do trabalho docente. Isso nos leva a refletir sobre as questões abordadas no texto em epígrafe, que demonstra a característica dinâmica do processo de formação, evidenciando que sempre há a necessidade de repensá-lo, pois se trata de um mover-se permanente entre o saber e o não saber.

Entendemos que, assim como nós, todos que se dedicam à formação de professores se encontram reiteradamente em situações inesperadas que exigem, muitas vezes, a invenção de novos caminhos ou de novas respostas para as questões atinentes à complexidade de um ofício para o qual nos preparamos e que está sempre em processo de fazer-se a cada experiência.

Ser docente e formar professores supõe necessariamente estar aberto não somente à dúvida e ao questionamento, mas, sobretudo, à confrontação de múltiplos olhares para poder contemplar perspectivas que não supomos ver. Sendo assim, o universo de possibilidades abertas nesta coletânea é bastante amplo e o conjunto de artigos ora apresentados contempla uma parte importante das diversas tendências e sentidos da formação de professores no Brasil.

\footnotetext{
${ }^{1}$ CASTRO, R. P. de. Formação Docente, subjetividades e experiência: problematizações a partir dos percursos, pela pesquisa e pela docência. In: FERRARI, A. (Org). A potencialidade do conceito de experiência para a educação. Juiz de Fora: Ed. UFJF, 2013, p. 139).
} 
Sem a pretensão de esgotar a temática, o conjunto de capítulos aqui reunidos, revela a diversidade de perspectivas e enfoques sobre a formação docente e apresenta nuanças muito instigantes, pela contribuição de pesquisadores das regiões Norte, Nordeste, Centro-Oeste, Sudeste e Sul. Esta obra é, portanto, representativa de todas as regiões do Brasil. Desse modo, é no conjunto das mentes que sobre o tema aqui se debruçam que o leitor poderá encontrar algumas reflexões relevantes para os dilemas que envolvem as práticas de formação de professores.

Como veremos nesta obra, os estudos acadêmicos produzidos estão muitas vezes relacionados a políticas públicas implementadas, que suscitam novas formas de se fazer e se pensar a formação docente, gerando profundos e necessários debates sobre o tema. Um incremento significativo sobre essa questão no cenário brasileiro se deu nos últimos anos, em decorrência de diversos programas governamentais voltados para a formação inicial e continuada de professores.

O conjunto de artigos que compõem esta publicação apresenta interpretações e análises que envolvem múltiplos olhares sobre o tema, incluindo questões como: a subjetividade na formação professores; formação docente e currículo; formação continuada e construção da identidade profissional; formação de professores no contexto da inclusão; tecnologias emergentes e formação de professores; ensino profissional e formação docente; relações étnico raciais e formação de professores; políticas de formação inicial de professores; estágio supervisionado e formação docente.

A presente obra representa, assim, uma rede de elaboração coletiva em torno do tema, construída por diversos profissionais de distintas instituições que formularam suas análises a partir de seus estudos e pesquisas. A seguir, apresentaremos cada um dos trabalhos de modo a orientar o leitor em um mergulho qualificado e atualizado no tema.

No capítulo de abertura do livro, intitulado "O papagaio e descartes": uma reflexão sobre a subjetividade na formação de professores do idioma estrangeiro, os autores se fundamentam em suas experiências de trabalho com a prática de ensino de língua inglesa, para analisar questões relacionadas a "objetividade" e "subjetividade" nas discussões sobre a formação de 
professores do idioma estrangeiro no Brasil. Partindo de um conto intitulado “O Papagaio e Descartes”, da escritora Guianense Pauline Melville, os autores exploram a necessidade de se repensar o "cartesianismo" e o racionalismo nos processos de formação docente. $\mathrm{O}$ estudo demonstra o quanto o objetivismo tem influenciado nossa percepção e nossa avaliação sobre o que é "bom" e "ruim", o que é considerado digno de ser aceito como "verdade" ou não. Os autores concluem enfatizando a presença marcante da subjetividade no processo de formação, propondo um traçado sócio histórico a partir dos conceitos de processo identitário e trabalho intersubjetivo para dar vez e voz à subjetividade dos professores em formação.

O estudo intitulado Aportes teóricos para construção de um currículo rizomático na formação de professores consiste em uma reflexão teórica acerca do currículo nos cursos de formação de professores. As autoras analisam os desafios que são postos aos docentes na sociedade atual e a incapacidade de o currículo "arbóreo" contribuir para uma formação que se contraponha à racionalidade técnica e que entenda o conhecimento como construção coletiva, temporal e sempre renovado. Debruçam-se sobre o conceito de rizoma, que tem como características os princípios de conexão e de heterogeneidade para se pensar no currículo dos cursos de licenciatura. Apresentam novos modos de se pensar as propostas curriculares pela perspectiva rizomática de estrutura do conhecimento. Concluem que a proposição de reflexões sobre o currículo rizomático busca a construção de pensamentos menos rígidos e possibilidades de vislumbrar leveza e criação nos processos acadêmicos de formação de professores.

No capítulo seguinte, Formação continuada na educação infantil e suas contribuiçôes para a construção da identidade profissional, os autores apresentam resultado de pesquisa realizada acerca do processo se formação continuada, desenvolvido em dois cursos de formação para os professores de Educação Infantil de uma rede pública municipal. O primeiro foi o Curso de Especialização em Docência na Educação Infantil (CEDEI), seguido do Curso de Extensão em Docência em Educação Infantil (CEEI), realizados em uma parceria entre o Ministério da Educação (MEC), uma Universidade Federal e uma rede pública 
municipal. O aporte teórico-metodológico subsidiou-se pela pesquisa bibliográfica e nos documentos legais que norteiam a referida etapa no contexto brasileiro. A pesquisa se caracteriza como exploratória e possui uma abordagem qualitativa. Os instrumentos de coleta de dados utilizados foram a observação não participante e a análise documental dos trabalhos e pesquisas acerca dos referidos cursos. Conclui-se que o conhecimento obtido na formação continuada, a exemplo do CEDEI/CEEI, interfere diretamente na perspectiva das práticas pedagógicas, na formação do educador pesquisador e no cotidiano escolar, bem como no processo de construção/fortalecimento da identidade profissional.

A formação do professor no contexto da inclusão é o tema sobre o qual se dedicam as autoras, que consideram o processo formativo do professor nos diversos níveis e modalidades de ensino como fator importante na discussão da melhoria da educação e na construção de escolas inclusivas. Apresentam resultado de pesquisa exploratória, cuja tipologia baseou-se na investigação documental e bibliográfica fundamentada em autores que tratam da temática. $\mathrm{O}$ estudo propõe reflexões sobre a lógica elitista e excludente da instituição escolar e indica a necessidade de que tais paradigmas sejam rompidos, a fim de garantir que a formação, tanto a inicial quanto continuada, seja pensada com base na realidade da escola. Conclui que a ação educativa não é um ato neutro e estar no magistério exige comprometimento político, ético e social.

No capítulo que se segue, Tecnologias emergentes e formação de professores, é o foco do autor que contribui com o debate acerca da presença das tecnologias digitais como mediadores no processo de ensino na formação inicial de professores. Para o autor, torna-se imperativo problematizar a constituição dos cursos de formação de professores em meio a esse contexto atual de forte incidência das tecnologias emergentes no cotidiano social. Mediante o estabelecimento de relações entre as grades curriculares dos cursos de Pedagogia das sete universidades federais das capitais dos estados da Região Norte do Brasil e as perspectivas pedagógicas contemporâneas, como educação híbrida, uso educacional de tecnologias móveis e aprendizado ubíquo, o capítulo apresenta discussões e indica questionamentos 
considerados fundamentais para pensar uma formação de professores sintonizada com o uso dessas tecnologias no dia-a-dia de universitários e estudantes da Educação Básica. Toma-se como conceito basilar o de mediação, de Lev S. Vygotsky, adotando a Psicologia Histórico-Cultural da Atividade (CHAT) como referencial teórico. Ao longo do texto, busca-se consubstanciar a hipótese de que tanto os cursos de formação de professores, como as práticas escolares, de forma geral, enfrentam dificuldades para incorporar pedagogicamente ferramentas tecnológicas já utilizadas em grande escala nas práticas e nas relações sociais da população brasileira. Diante desse cenário, o autor lança os questionamentos: qual a carga horária total das disciplinas voltadas ao uso educacional das tecnologias emergentes no currículo dos cursos de Pedagogia? Com que intensidade o uso dessas tecnologias é incentivado e efetivamente trabalhado pelos acadêmicos de Pedagogia ao longo do curso? A "cultura tecnológica" está incorporada no percurso da formação docente?

$\mathrm{Na}$ sequência, a autora do artigo $A$ formação de professores da educação profissional: desafios e possibilidades registra uma experiência de formação em serviço com professores inseridos no Programa Nacional de Acesso ao Ensino Técnico e Emprego (Pronatec), criado pelo Governo Federal em 2011 e implementado no Centro de Educação Profissional, instituição vinculada à Universidade Federal do Triângulo Mineiro e subordinada à SETEC - Secretaria de Educação Profissional e Tecnológica/MEC. Com base nos estudos e pesquisas nacionais, a autora analisa as relações e mediações entre o Estado e a política pública de educação profissional no âmbito do programa de implementação do Pronatec no Brasil. Em seguida, relata as experiências vivenciadas no Projeto de Formação Pedagógica em serviço para os professores-bolsistas do Pronatec-Cefores-UFTM. Registra os desafios encontrados nas escolas de educação profissional que recebem profissionais oriundos de diferentes áreas de formação, para atuar como professores, uma vez que não há exigência de requisitos legais de formação como docente nessa modalidade de ensino. A autora conclui que a significativa taxa adesão ao curso evidencia a importância da formação em serviço para o "fazer-se docente" no âmbito do ensino profissional. 
Em Formação de professores e relações étnico raciais: questôes sobre a temática indígena nas escolas, as autoras relatam a experiência de formação continuada de professores desenvolvida em um curso de aperfeiçoamento voltado para qualificar a abordagem sobre a cultura indígena nas escolas, conforme determinação da Lei 11.645/2008. As autoras analisam aspectos teóricos da formação docente e se fundamentam em pesquisas acadêmicas para examinar os estereótipos da cultura indígena no ambiente escolar. A experiência corrobora o entendimento de que a desconstrução gradual de preconceitos e estigmas com a cultura e história dos povos indígenas, nas escolas, exige a formulação de estratégias de formação continuada de professores, bem como a ampliação de espaços de debate e reflexão que fomentem o protagonismo de povos e lideranças indígenas nesse processo.

O capítulo intitulado Politicas de formação inicial de professores: experiências do pibid e a práxis docente analisa os impactos do Pibid, com foco na Gestão Escolar, na formação inicial de professores. O campo empírico consiste em diferentes registros e dados gerados pelos/as licenciandos bolsistas ao longo dos últimos dois anos no projeto, considerando que a dinâmica de trabalho do Pibid/Gestão envolveu diagnóstico da escola em geral e, especificamente, da gestão das escolas por meio de questionários, entrevistas, observações e análise documental; planejamento dos projetos de intervenção e dos planos de atividades, com linhas de ação definidas a partir do mapeamento da realidade da instituição escolar. As autoras tecem reflexões sobre a formação inicial de professores/as por meio da práxis e concluem que o programa gera impactos expressivos tanto na formação inicial dos/as bolsistas/estudantes, quanto na formação continuada dos/as professores/as e gestores/as da Educação Básica envolvidos direta ou indiretamente no Pibid.

No capítulo seguinte, Naturalização do estágio e invisibilidade do trabalho (do estágio curricular obrigatório): uma tese em construção, a autora concebe o estágio como campo privilegiado da formação de professores, visto que está na intersecção entre a universidade e a escola, entre a formação inicial e a formação continuada, entre teoria e prática. A relação dada entre universidade e escola básica é entendida no artigo como ação inerente 
ao estágio, enquanto o estágio é, diferentemente da compreensão imediata de uma disciplina, um campo "nucleador do curso". A exposição da autora pretende, com base na leitura bibliográfica e documental, produzir um cenário que inscreve a prática de ensino/estágio no fio histórico, emblematizado pelos efeitos da resolução n.9 de 1969. Na sequência, dialoga com a literatura especializada, identificando os desafios da realização do estágio na "escola real", de 1969 aos dias de hoje, culminando com os programas oficiais da política nacional de formação de professores (Pibid e Residência Pedagógica). Por fim, promove a exposição e análise de dados parciais da pesquisa Recortes da relação entre formação e atuação docente no estágio, obtidos pelos questionários que envolveram dois sujeitos da pesquisa: professor supervisor (escola), estagiários (futuro professor); e pelo estudo documental de Projetos político pedagógicos das instituições abrangidas pela pesquisa.

O capítulo que encerra a presente coletânea, intitulado Letramentos digitais e formação inicial de professores para a educação online, apresenta uma análise das formações para o uso do ambiente virtual Moodle, no curso de Licenciatura em Pedagogia, modalidade a distância, observando o seu desenho didático como disparador de dimensões e habilidades de letramentos digitais. Traz como problema: quais conhecimentos são necessários à formação inicial de professores com o uso de tecnologias digitais que possam favorecer a mobilização de habilidades de letramento digital para atuar na educação online e promover a inclusão cibercultural dos estudantes? A metodologia usada é da pesquisa-formação na cibercultura, em diálogo com a multirreferencialidade, e o dispositivo de pesquisa é o ambiente virtual de aprendizagem e suas atividades. A autora conclui destacando os desafios relacionados e formação inicial de professores com tecnologias digitais, as potencialidades das práticas e eventos de letramento digital desenvolvidos e as necessidades relacionadas ao uso do digital em rede. Aponta, ainda, possibilidades para a continuidade da formação ao longo do curso para promover a inclusão cibercultural dos estudantes futuros professores.

Entendemos que a maior contribuição deste livro é o que ele proporciona em termos da multiplicidade de olhares sobre diferentes aspectos da formação de professores, de modo que, diante da diversificação de ideias, 
a intenção é que o leitor possa instigar e desestabilizar visões, tornando-se estimulado para o aprofundamento da questão.

Expressamos aqui nossos mais profundos agradecimentos aos autores, pelas contribuições substantivas que nos trazem. Esperamos que esta obra coletiva, resultado do diálogo interdisciplinar e interinstitucional, contribua para a permanente mobilização em torno do repensar a educação bem como para o desenvolvimento de estudos e pesquisas na área de formação de professores.

Finalmente, destacamos que esta obra representa experiências de trabalho em desenvolvimento e, assim, estão inscritas e datadas no tempo. Muitas outras contribuições são possíveis e até indispensáveis para a compreensão dos elementos que enredam a questão mais amplamente. É com essa consciência da natureza inacabada da história do tempo presente que o livro aqui apresentado se caracteriza por sua provisoriedade, desafio para outros estudos, pesquisas e publicações.

As organizadoras 


\section{1. "O PAPAGAIO E DESCARTES": UMA REFLEXÃO SOBRE A SUBJETIVIDADE NA FORMAÇÃO DE PROFESSORES DO IDIOMA ESTRANGÉIRO' ${ }^{1}$}

Miguel Nenevé

Lusinilda Carla Pinto Martins

\section{Introdução}

Gostaríamos de introduzir nossa reflexão com um fato evidente em nossa universidade. Em uma placa de informação para turistas no prédio antigo da Universidade Federal de Rondônia, conhecida por UNIR desde a sua fundação em 1982, encontramos a informação em inglês: "Universidade Federal de Rondônia - UNITE was founded...." O fato de traduzir UNIR - literalmente demonstra como se desconsidera o local, a história, o sujeito. Quando nos referimos à língua estrangeira parece que logo temos que pensar em algo totalmente racional, cartesiano, universal em que devem ser esquecidas todas as particularidades, onde tudo tem que ser objetivo, racional e inflexível. Não se consideram as particularidades do local, da história do sujeito, das suas particularidades. No caso de nosso exemplo, o fato de a tradução ser feita por uma empresa de fora da cidade contou muito. Pensou-se de uma forma cartesiana, racional, considerando que o verbo unir traduz-se por "Unite" então a UNIR, instituição, também é "Unite." Não se considerou que UNIR é um nome, que neste caso é um substantivo e não um verbo. Apagaram-se o contexto, a história e toda a subjetividade. Neste artigo, gostaríamos de discutir a importância de se pensar a subjetividade quando pensamos em língua estrangeira, com o foco na formação de professores. Consideramos que haja a necessidade, primeiramente, de explorarmos o tema "subjetividade". Acreditamos que é muito relevante - mesmo reconhecendo que hoje não se concebe mais a matematização

\footnotetext{
${ }^{1}$ Uma versão deste artigo foi publicada na Revista Igarapé, v. 11, n. 1 (2018).
} 
do conhecimento nem a institucionalização de verdades inquestionáveis explorar questões referentes ao cartesianismo em relação à subjetividade.

\section{Cartesianismo e objetividade versus subjetividade no ensino}

$\mathrm{Na}$ evolução do pensamento científico, a noção de cientificidade se configura com base na objetividade e na neutralidade. $\mathrm{O}$ empirismo lógico e o modelo cartesiano de ciência instituíram uma concepção de objetividade marcada respectivamente pela prova do intelecto e pelas provas dos sentidos. O Cartesianismo surgiu com a importante obra do francês René Descartes, cujo título original "Discours de la méthode pour bien conduire sa raison, et chercher la vérité dans les sciences" sugere que esse era o método de conduzir corretamente nossa razão, na procura da Verdade nas Ciências. Importante lembrar que o livro foi publicado em 1637, período em que a Europa estava saindo para outras terras, conquistando povos, colonizando terras não europeias. Isso certamente ajudou a fomentar a ideia que a Europa poderia levar para suas colônias, em sua missão civilizadora, o método de conduzir corretamente a razão e logicamente combater tudo o que não dizia respeito ao mundo europeu e que era irracional.

Trabalhando sob uma crença humanística, cuja ideia central era que o ser humano, apesar de suas diferenças, tinha uma natureza universal recebida de Deus, René Descartes (1977), ao escrever isso em 1619, de certa forma estava tentando fazer sentido do mundo, e querendo explicar o que todos os humanos sabem com certeza. Nesse aspecto, podemos dizer que filosofia cartesiana colocou os seres humanos europeus no centro de seu mundo e permitiu que eles acreditassem que a natureza podia ser controlada por meio da aquisição de conhecimento, a classificação e a análise de seu mundo circundante. Simplificando, poderíamos dizer que essa maneira de ver o mundo favoreceu a crença de que o europeu era o universal e vice-versa. Dessa forma, este "pensamento científico" reforça a noção de que as particularidades de outros mundos, outras percepções de verdade, ou poderíamos dizer, subjetividade, não devem ser consideradas, pois podem até ser nocivas ao processo de produção do conhecimento. Portanto, dessa 
perspectiva, não se deve falar de seu mundo, mas receber a verdade racional, cartesiana, indiscutível.

O pensador e crítico pós-colonial australiano Bill Ashcroft (2002) explica que a separação cartesiana do sujeito e do objeto, a separação da consciência do mundo do qual se é consciente, é o esquema que ainda guia a episteme do mundo ocidental, com sua obsessão pelo "científico", pela objetividade, com sua tendência a ver o mundo como a continuação de dados tecnológicos (Ashcroft, 2002, p.67). Essa visão de mundo nega, exclui ou suprime tudo o que não é ocidental, todo o conhecimento que foge de um padrão preconcebido. Nesse contexto, se formos mais além, podemos induzir que a filosofia cartesiana produziu maneiras de perceber o mundo que posiciona o europeu branco (colonizador) como o centro do mundo, tendo a responsabilidade de educar o outro, o ignorante, de trazer para a racionalidade, para o "progresso", aquele que caminha em outro ritmo, que vê o mundo de outra perspectiva.

No conto “The Parrot and Descartes", presente no título deste artigo, a escritora britânica, nascida na República da Guyana, satiriza essa percepção cartesiana que faz que a Europa separe o conhecimento científico da magia, contrastando a visão de um papagaio de Orinoco com a de um pensador europeu, Descartes. A história na realidade debocha do cientificismo europeu que não serve para explicar a realidade Ameríndia. Essa história da autora guianense serve para reforçar nosso argumento sobre o perigo de querer tornar-se científico e racional e esquecer a subjetividade em nosso meio educacional.

Essas correntes encontraram guarida no positivismo de Comte (1798) e no neopositivismo de Carnap (1891-1970), que reforçam, como critérios de cientificidade, a objetividade e a neutralidade, em detrimento da subjetividade e dos valores (Araújo, 2003, p. 145).

A ciência deve apoiar-se basicamente na realidade empírica e dotar-se de uma linguagem acerca de fenômenos que independe de juízos de valor, finalidades e interesses, pois estes dizem respeito à subjetividade que é em tudo estranha à ciência. Sendo a subjetividade um empecilho 
à objetividade, que deve haver em qualquer proposição com pretensão científica, o mais seguro para a ciência é adotar o modelo da física e da química.

Tal orientação, na área das ciências sociais e humanas, nos permite entender as bases da relação conflituosa entre objetividade/subjetividade. O pensamento científico positivista reforça, em suas proposições, o mito de que a subjetividade é nociva ao processo de produção do conhecimento.

A evolução do pensamento científico associa-se à adoção do método. Essa postura sistemática e racional proporciona um rigor metodológico e instaura a noção de cientificidade para o conhecimento. A concepção paradigmática de Kuhn desfaz esse padrão de racionalidade ao estabelecer que a adoção deste ou daquele paradigma (no momento da crise) não segue os critérios racionais "da razão externa, neutra, atemporal e comum a teorias rivais" (ASSIS, 1993, p. 138-139). Entretanto, ainda segundo Assis, é errôneo julgar que Kuhn propõe uma forma irracional na decisão entre paradigma, pois não há como pesar racionalmente todos os fatores a serem levados em conta na decisão de se abandonar ou não um paradigma, sob pena de acusação de inconsistência ou irracionalidade para quem não os admita.

Coracini (1991, p.105), ao fazer um estudo sobre a subjetividade presente no discurso da ciência, observa que o discurso científico "é largamente um discurso sobre as coisas, onde um ele não-humano é o sujeito de verbos de estado e de processo". A autora discute não apenas o mito da objetividade da ciência, mas a objetividade do discurso científico que se supõe neutro, imparcial e impessoal. Ela deixa claro que o ideal positivista de ciência rejeita a subjetividade na atividade científica, conforme podemos perceber no excerto abaixo:

Como seria de se esperar em vista das convenções científicas, o sujeito enunciador assume, o tempo todo, a postura de um observador distante do objeto observado, como que provando, com sua ausência explícita, a ausência do sujeito pesquisador na etapa da investigação científica (Coracini, 1991, p.104). 
Por todo o exposto, observamos que objetividade e subjetividade são constitutivas do fazer científico e guardam sua positividade. A objetividade - marca maior da ciência clássica e aliada ao rigor e à precisão - nos proporcionou descobertas importantíssimas sobre o mundo em que vivemos. E a subjetividade, da mesma forma, impulsionou a ampliação e a criação de novos campos do conhecimento (ciências sociais e humanas) bem como desmitificou a prática científica, reconhecendo-a como uma atividade pautada não somente por regras a serem seguidas, mas guiada também pela criatividade do cientista.

Não é intenção deste estudo priorizar nem a objetividade e nem a subjetividade nas pesquisas científicas, mas fazer uma observação de que ambas são constitutivas da prática científica e que, portanto, não devem ser vistas sob a ótica maniqueísta e nem tratadas de maneira excludente.

\section{A (indesejável?) subjetividade na formação de professores}

Ao problematizar a forma de produzir e disseminar conhecimento na área educacional, Souza (2008, p.66) legitima nossa ideia de que a subjetividade se faz indesejável porque:

A Educação tende a expurgar o afeto e a considerar a dimensão subjetiva como propiciadora do erro e da falha nos processos de produzir e de disseminar conhecimento. De maneira geral a Educação adota a concepção do sujeito da razão plena capaz de controlar os afetos e de expurgá-los do processo psíquico e cognoscente de ensinar e de aprender.

Nos termos da autora, esse pensamento cartesiano, linear e positivista de racionalidade tem promovido uma cisão entre processos que são recíprocos e relacionais: os processos de conhecer e de subjetivar. Souza (2008) nos lembra que, ao contato com novos conteúdos, situações e experiências, isto é, no processo de aprender, somos constrangidos a um trabalho cognoscente bem como a um trabalho subjetivo. Nas palavras de Souza (2008, p.64): 
O processo de conhecer se articula ao processo de subjetivar na medida em que o contato estabelecido com o real, seja para elaborar nossa capacidade cognoscente, seja para construir nossa subjetividade, é recíproco e relacional.

Nesse sentido, a autora propõe, para o trabalho educacional, "a presença de uma relação que possibilite aos participantes lidar com a dúvida e com os limites inerentes à aquisição de novos saberes e fazeres" (Souza, 2008, p.67). Tal pensamento vai de encontro ao que de fato acontece na prática. $\mathrm{O}$ que comumente acontece, no processo de formação, é o adiamento da dúvida, dos limites em detrimento do desejo de homogeneização. A subjetividade, assim, apresenta-se indesejável.

Em estudos anteriores, referentes à formação de professores de língua inglesa, por exemplo, já observávamos que o ponto nodal da Prática de Ensino, no curso de Letra-Inglês, ligava-se ao fato de essa disciplina formativa não encarar a heterogeneidade como constitutiva da formação do futuro professor (MARTINS, 1998). Os resultados de tais estudos mostraram que a Prática de Ensino de Língua Inglesa, ao abafar a heterogeneidade $\mathrm{da} /$ na sala de aula, escamoteava as contradições e os conflitos inerentes ao processo de formação, limitando-se à legitimação e à instrumentalização do professor de língua inglesa. Os estudos proporcionam a seguinte reflexão:

A $\mathrm{PELI}^{2}$, sob pena de perder o controle do processo de formação e porque determinada pelas regras do discurso pedagógico e institucional, que tendem a mascarar a heterogeneidade de todo discurso, procura abafar esses conflitos. Conflitos esses perpassados pelas relações de poder que se estabelecem na sala de aula. Dessa forma, essa disciplina busca transformar a sala de aula num espaço homogêneo para a aplicação de metodologias e para o desenvolvimento de atividades cognitivas (Martins, 1998, p.91).

Nessa perspectiva, observamos que toda ocorrência de heterogeneidade é "abafada" em nome da unidade e da homogeneização do processo

${ }^{2}$ Prática de Ensino de Língua Inglesa - PELI. 
de formação. O desejo de tal homogeneização também é captado por Josso (2002, p.199) no que diz respeito à noção de universalização do processo de formação expressa no excerto a seguir.

A arte do tempo para o professor / formador não termina nesta gestão visível. Na sua programação, ele integrará, com maior ou menor felicidade, o que se sabe de si mesmo relativamente às suas energias disponíveis e aos seus diversos compromissos. Mas mesmo aí, a tarefa não está terminada, porque se sabe confrontado com a heterogeneidade do grupo e, logo, com as especificidades de cada aprendiz na atividade educativa. Cada professor/formador sabe disso e, no entanto, construímos os nossos cenários pedagógicos como se só tivéssemos de fazê-lo para um homem universal, espécie de protótipo ou de tipo ideal de aprendiz neste ou naquele período da vida.

Tomando como base todas as discussões referentes ao desejo de homogeneização do/no processo de formação, portanto, de exclusão da subjetividade, podemos compreender a dificuldade de operacionalização da epistemologia da prática na formação de professores. Mateus (2002, p. 11) reforça nossa compreensão ao assegurar que:

[...] o novo paradigma que vem sendo apresentado para os cursos de formação dos professores ainda levará anos até que seja compreendido e aceito por um sistema educacional totalmente voltado ao racionalismo técnico, no qual a aquisição do conhecimento teórico deve servir ao aprimoramento da prática.

Telles (2002) comunga tal pensamento, ao reconhecer as limitações de operacionalização da epistemologia da prática, denunciando a ausência generalizada de uma pedagogia da positividade e de um entendimento do professor detentor de conhecimentos práticos. Para tanto, aposta na pesquisa narrativa como processo emancipatório e como instrumento de acesso à subjetividade dos professores: 
A proposta da Pesquisa Narrativa é a de uma prática emancipatória de formação de professores. Tal prática abre espaços aos seus participantes para a construção de um auto-conhecimento, o conhecimento de sua subjetividade em relação direta com o conhecimento de sua própria prática profissional. Assim, ficam os professores em posição de agenciadores de suas próprias transformações; pois ninguém transforma ninguém. As pessoas se transformam em função de seus desejos (Telles, 2002, p.23) (grifos nossos).

As reflexões de Telles sobre práticas investigativas que favoreçam o conhecimento da subjetividade encontram eco no questionamento de Barreiro (2006) de que, além da dimensão instrumental-cognitiva da ação docente, necessitamos compreender essa ação a partir de um terceiro elemento, concernente às intenções e às escolhas do sujeito implicado nessa ação. Dito de outro modo, a autora defende que a ação docente transcende a concepção restrita de um saber-fazer, uma vez que pressupõe a mediação do sujeito. Esse terceiro elemento, pois, reitera a subjetividade.

Outros fatores que tornam a subjetividade indesejável, nas investigações sobre a formação de professores, referem-se (i) à dificuldade de lidar com a singularidade do sujeito, (ii) ao centramento da perspectiva social nas discussões sobre identidade mediante um "esquivar-se" da dimensão individual, e (iii) ao enfoque estritamente cronológico dado às discussões sobre a temporalidade da não formação.

$\mathrm{Na}$ contramão desses esquivamentos e restrições presentes na discussão da subjetividade no processo de formação de professores, Tardif (2002) comenta o assunto asseverando que os professores são sujeitos do conhecimento e possuem saberes específicos ao seu ofício. Dessa forma, o autor caracteriza três grandes orientações que tratam da subjetividade dos professores.

A primeira orientação, denominada cognição e pensamento dos professores, refere-se a pesquisas de abordagem psicológica ligadas à cognição. Tais pesquisas, porque apoiadas na visão cognitivista e psicologizante, reduzem a questão da subjetividade a uma racionalidade intelectual 
e instrumental. Na América do Norte, segundo Tardif (2002), o ensino é concebido como um processo de tratamento da informação e as investigações priorizam os processos mentais que regem o pensamento do professor. Nesse sentido, os saberes do professor são definidos como "representações mentais a partir das quais os práticos ordenam suas práticas e executam suas ações" (TARDIF, 2002, p.231); trata-se, portanto, de saberes procedimentais e instrumentais que permitem, ao professor, elaborar uma representação da ação e lhe dar forma. $\mathrm{Na}$ Europa, as pesquisas se orientam pelo viés construtivista e socioconstrutivista e se interessam pelos "processos de negociação, de ajustamento e de estruturação das representações mentais subjetivas e intersubjetivas dos professores relacionados com o contexto de ensino, com as interações com os alunos e também com as outras dimensões simbólicas do ensino [...]” (TARDIF, 2002, p.231). As pesquisas, desta feita, evidenciam o professor perito e eficiente.

$\mathrm{Na}$ segunda orientação, aparecem as pesquisas de ordem fenomenológica que englobam temas como "história de vida pessoal e profissional, crenças, a voz dos professores, enfoques narrativos, metáforas, relatos, dentre outros"(TARDIF, 2002, p. 232). O professor é considerado sujeito ativo de sua própria prática. Essa segunda orientação está inserida em uma visão existencialista cujo interesse volta-se para o professor experiente com seus dilemas, tensões e rotinas.

Por fim, a terceira orientação estende-se pelo campo da sociologia dos atores e da sociologia da ação. Esses campos de estudos estão associados

[...] ao simbolismo interacionista, à etnometodologia, ao estudo da linguagem comum e cotidiana, ao estudo da comunicação e das interações comunicacionais, às competências sociais e aos saberes sociais dos atores, etc. (TARDIF, 2002, p.233).

Dessa perspectiva, a subjetividade não se reduz à cognição ou à vivência pessoal, mas "remete às categorias, regras e linguagens sociais que estruturam a experiência dos atores nos processos de comunicação e de interação cotidiana” (TARDIF, 2002, p.233). 
As orientações expostas por Tardif (2002) promovem um redimensionamento no cenário das pesquisas em educação, ao deslocar a discussão sobre formação e subjetividade do âmbito racional-metodológico para o âmbito processual.

Acompanhando tais orientações, este estudo pretende assumir o estágio como um espaço de desenvolvimento de experiências pessoais e profissionais e, principalmente, de constituição de sentidos e de produção de saberes. Relembrando que a subjetividade do processo educacional ocorre na relação de mediação entre a interioridade e a exterioridade do sujeito, entendemos o estágio supervisionado como uma prática simbólica. Assim, sempre que nos reportamos às ações dos professores em formação, estaremos falando de seus conceitos e valores, os quais dão sentido à prática e são socialmente construídos e historicamente consolidados.

Nesse momento, parece necessário fazermos uma breve incursão por conceitos que nos auxiliem na compreensão sobre a docência e sua complexidade constitutiva, focalizando marcas da subjetividade no processo de tornar-se professor. Passemos, então, a considerar alguns conceitos envolvidos neste estudo que nos auxiliará a evidenciar essas marcas e aprofundar a discussão e a reflexão sobre a presença (sempre) da subjetividade no processo de formação inicial de professores.

\section{Subjetividade: da identidade, da singularidade e da temporalidade do formar-se}

Embora este estudo não esteja inserido em uma abordagem narrativa de pesquisa e, portanto, não trilhe os caminhos para a realização de investigações sobre história de vida, buscamos respaldo em alguns pontos levantados por Josso para abordar questões ligadas à subjetividade do/no processo de formação de professores.

Josso (2002, p.197) deixa transparecer a ideia de que a formação não pode ser tratada como uma homogeneidade porque é constituída de vários aspectos. Primeiramente, remete a formação a um processo de aprendizagem de competências e de conhecimentos técnicos e simbólicos. 
Com base em correntes metodológicas ${ }^{3}$ atuais relativas à formação, apresenta o conceito de "impermanência" para designar a tomada de consciência mais primitiva que o $e u$ pode fazer na observação/exploração de si mesmo e do seu meio humano e natural. A autora questiona a geografia de categorias descritivas para abordar a heterogeneidade dos grupos e propõe a singularidade como paradigma associado ao conceito de humano, ao afirmar que:

Esta singularidade, se formos sensíveis a ela em cada instante da nossa prática, impõe-se como a maior limitação da nossa atividade. Ela é tão radical que a fenomenologia do encontro nos faz descobrir, a cada instante, o mistério de cada ser e quebra o aparente pré-conhecimento que tínhamos por meio da integração das ciências do humano (Josso, 2002 p.199).

A singularidade, na visão da autora, remete à temporalidade no processo educativo. Esse posicionamento encontra amparo na própria definição de singularidade. Remetendo-nos ao conceito dicionarizado, singular significa, de acordo com os verbetes um e dois, 1. pertencente ou relativo a um. 2. Especial. Raro. Na sequência, Singularidade é definida nos seguintes termos: 1. Qualidade, estado ou condição do que é singular. 2. Ato ou dito singular. 3. Região do espaço-tempo onde as leis da física atualmente conhecidas entram em colapso e as equações perdem o seu significado.

Podemos entender, com base na ideia de colapso expressa no verbete três, as argumentações de Josso (2002) referentes à relação singularidade-temporalidade. A autora, por exemplo, postula "que a gestão da temporalidade sócio pedagógica, encarada pela perspectiva do professor/ formador, choca-se com a gestão da temporalidade sócio individual" (p. 199). $\mathrm{Na}$ oportunidade, a pesquisadora tece críticas às pedagogias cujos pressupostos apontam para um processo de aprendizagem de correspondência unívoca do tipo: o professor ensina, o aluno aprende. Ao contrário, propõe a noção de autopoeisis para subsidiar as investigações sobre o ser aprendiz que é considerado ser autopoiético, e entendendo o ato educativo

\footnotetext{
${ }^{3}$ Em particular da formação experiencial, a das histórias de vida em formação, bem como da pesquisa-formação. (Josso, 2002, p.197)
} 
como violador da temporalidade autopoiética. A autora, então, se autoquestiona: "visto que só o aprendiz pode aprender a aprender, qual é o meu lugar, o meu papel, o meu estatuto, a minha missão de professor, formador, educador junto a ele?" (Josso, 2002, p.200).

A reflexão da autora reforça a ideia de que o tempo do processo de aprendizagem é condicionado pela singularidade de cada aprendiz. A mudança só ocorre mediante uma tomada de consciência e, mesmo assim, Josso (2002) insiste na não equivalência entre a temporalidade da aprendizagem e a temporalidade da mudança.

Se a formação envolve um processo de mudança, Josso (2002, p.203), detendo-se um pouco mais sobre a temporalidade e singularidade, chama atenção para o fato de "que o processo de formação é posto entre parêntesis, fora do campo da consciência, para se ocupar do que é mais urgente aqui e agora". A autora continua sua reflexão

[...] o aqui e agora é apenas o local de uma experiência obrigatória, suportada nos seus constrangimentos, mas não integrada numa prospectiva, não integrada como material de exploração, não integrada como experiência formadora de mudanças, não subordinada a um sentido para o indivíduo, não subordinada a uma procura, a uma orientação autoformulada a partir do seu patrimônio sociocultural (JOSSO, 2000, p.204)

Essa ponderação nos auxilia a explicar o porquê da experiência do estágio, nos programas de formação, funcionar, não raro, como uma atividade protocolar e esvaziada de sentido. Ao contrário, quando pensado como espaço para a subjetividade, o estágio pode se converter em uma experiência significativa na formação. Retomando a relação singularidade-temporalidade, Josso (2000, p.204) argumenta:

O respeito pelo tempo concedido à simbolização, à integração num imaginário, apresenta-se, então, como respeito à pessoa reconhecida na sua singularidade, quer dizer, nas diferentes dimensões do seu ser (as suas identidades) associadas a uma subjetividade impermanente [....]. 
A pesquisadora concebe a formação como uma construção de si e de sentido mediada pela temporalidade biográfica e chama a atenção para a conscientização da complexidade temporal da formação. Josso (2000) ainda menciona o trabalho intersubjetivo no processo de formação que encerra as identificações e diferenciações que o indivíduo faz durante o seu processo de estranheza do outro e de si mesmo.

Aproveitamos as contribuições da autora para abordar a subjetividade do/no processo de formação do professor de língua inglesa, sob a perspectiva da impermanência, da singularidade e da temporalidade.

A ideia de impermanência nos permite identificar a situação de intensa transitoriedade do futuro professor, devido ao fato de a experiência do estágio ir na contramão da estabilização de sentimentos, de práticas discursivas, de ações e reações. Longe de estabelecer uma identidade una, fixa e duradoura, as experiências do estágio são palco para a impermanência e, portanto, para a desestabilização das certezas, das verdades. A própria condição de estagiário assenta-se na intersecção do sujeito-aluno com o sujeito-professor.

A noção de singularidade, da mesma forma, nos autoriza a definir, neste estudo, o professor em formação como um sujeito singular que se constrói ao vivenciar as experiências proporcionadas pelo estágio supervisionado. $\mathrm{O}$ estágio, assim, configura-se como um tempo-espaço de produção da singularidade do futuro professor. Em outras palavras, funciona como ambiente produtor de contradições, de conflitos, de sentidos e significados.

A ideia de temporalidade se agrega a este estudo na medida em que compreendemos o estágio supervisionado como momento de passagem do ser aluno para o ser professor. Momento este marcado por experiências passadas e presentes que diferem de sujeito para sujeito, configurando-se, portanto, em um tempo singular do tornar-se professor.

Esse tornar-se professor, durante o estágio supervisionado, aparece em Nóvoa (1995, p.16) ligado à noção de processo indentitário pela "maneira como cada um se sente e si diz professor", dando-nos pistas sobre o eu pessoal e profissional. Essa apropriação da história pessoal e profissional, para o autor, é um processo complexo e não cumulativo (de cursos, 
conhecimentos e técnicas) que exige um trabalho constante de reflexão sobre as práticas e de construção de uma identidade pessoal (Nóvoa, 1995).

A noção de processo também é apoiada por Gatti (1996, p.86), ao afirmar que o professor é um ser em movimento, construindo valores, estruturando crenças, tendo atitudes, agindo em razão de um tipo de eixo pessoal que o distingue de outros: sua identidade. $\mathrm{Na}$ visão da autora, a identidade é, ao mesmo tempo, (i)um construto de origem idiossincrática, (ii) fruto das interações sociais complexas nas sociedades contemporâneas e (iii) expressão sociopsicológica que interage nas aprendizagens, nas formas cognitivas, nas ações dos seres humanos. Por essa razão é que a identidade define um modo de ser no mundo, num dado momento, numa dada cultura, numa história.

Para dar conta de identificar traços da identidade profissional, Nóvoa (1995, p.16) descreve três atitudes que fundamentam o processo identitário do professor: "adesão, ação, autoconsciência”. Após caracterizar as atitudes do seu triplo $A A A$, o autor enfatiza a identidade profissional dos professores como "um lugar de lutas e de conflitos, como um espaço de construção de uma maneira de ser e de estar na profissão" (Nóvoa, 1995, p.16).

Além de abranger as dimensões social e simbólica para dar conta dos processos pelo quais damos sentidos às práticas e às relações sociais, consideramos que a identidade é constantemente definida pela linguagem e pela relação com o outro, como nos sugere a afirmação a seguir:

A linguagem faz 'mais real' minha subjetividade não somente para meu interlocutor, mas também para mim mesmo. Esta capacidade da linguagem de cristalizar e estabilizar para mim minha própria subjetividade é conservada (embora com modificações) quando a linguagem se destaca da situação face a face (Berger; Luckman, 2002, p. 58).

A assertiva de que é por meio da materialidade linguística que podemos acessar nossa subjetividade nos antecipa que é pela linguagem - e mais propriamente pelo discurso -, que damos sentidos a nossa experiência pessoal, profissional e que buscamos, assim, "fixar" uma identidade. 
Nesse sentido, questionar a identidade significa reconhecer os sistemas de representação que lhe dão suporte e sustentação com o auxílio da linguagem (Silva, 2000).

\section{Breves considerações}

“O Papagaio e Descartes” de Pauline Melville sugere uma crítica ao pensamento puramente cartesiano que negligencia o conhecimento local, a percepção e os sentimentos não europeus e não canônicos. Procuramos argumentar, neste capítulo, que o papagaio, que no conto da escritora inglesa representa o sul-americano, o não europeu, aquele que não é muito "racional" nem "canônico' e "universal”, mas subjetivo, deve também ser valorizado e merece a atenção de educadores e de avaliadores. Como afirmamos no início, ao traduzir "UNIR" por "Unite”, negligenciou-se o valor da sigla de uma universidade pública na Amazônia. Essa desvalorização do local com sua peculiaridade, com sua história e sua inserção revela uma tendência a valorizar o único, o "universal" e o canônico quando se refere à língua estrangeira. Uma educação que acredita somente em "fatos universais", e negligencia o subjetivo, pode suprimir valores locais e inviabilizar uma formação voltada ao educando em seu ambiente. No que se refere ao ensino de um idioma estrangeiro, que discutimos aqui, precisamos prestar atenção no local, no ambiente em que se ensina a língua estrangeira. Não é possível ensinar uma língua estrangeira que desrespeite os valores e a cultura do aprendiz. Devemos pensar que o ensino de um idioma estrangeiro deve propiciar emancipação do estudante/ aprendiz e promover sua autoestima. É necessário ter cuidado para não causar um efeito contrário, isto é, levar o aprendiz a sentir-se inferiorizado por seu ambiente, seu sotaque, sua cultura e suas particularidades. Quando falamos em "formação de professores” de língua estrangeira, essa discussão é imprescindível.

Considerando, pois, a presença marcante da subjetividade no processo de formação, propomos um traçado sócio histórico a partir dos conceitos de processo identitário e trabalho intersubjetivo para dar vez e voz à subjetividade dos professores em formação. Professores em formação saem de seus 
mundos com suas histórias, suas culturas, suas vivências. Isso não pode ser desconsiderado em contexto de formação de professores. É preciso reforçar a necessidade de prestar atenção aos conceitos de subjetividade como processo identitário, marcado pela singularidade e pela temporalidade biográfica do sujeito, isto é, como uma produção sócio histórica, e de linguagem como uma dimensão discursiva.

Nosso argumento é que, ao refletirmos sobre a formação de professores de língua estrangeira, não podemos pensar a língua como inflexível, com um único "accent” e uma única maneira de se expressar. Portanto, não se pode medir tudo por dados, por medidas mecânicas, por números e por uma única forma de se expressar. Há muito mais dados que devem ser considerados e que não são mensuráveis. Como diria o personagem narrador de Pauline Melville em The Ventriloquist's Tale, "a vida de uma pessoa não está pendurada entre duas datas como uma rede que fica pendurada entre duas árvores”. Há muito mais na vida de um humano.

\section{Referências}

ARAUJO, I. L. Introdução à Filosofia da Ciência (Introduction to the philosophy of science) (p. 145-149.). Curitiba: UFPR, 2003.

ASHCROFT,B. Post-colonial Transformation. London and New York: Routldege, 2002.

ASSIS, J. P. Kuhn e as ciências sociais (Kuhn and the Social Sciences). Estudos Avançados (Advanced Studies), v.7, n.19, p.133-164, 1993

\section{BARREIRO, I. M. F.; GEBRAN, R. A. Prática de ensino e estágio supervisionado}

na formação de professores. São Paulo: Avercamp, 2006.

BERGER, P.; LUCKMANN, T. A. A construção social da realidade (The social construction of reality), 24. ed. Petrópolis: Editora Vozes, 2004.

CORACINI, M. J. F. Um fazer persuasivo: O discurso subjetivo da ciência (Persuasive action: The subjective discourse of science). São Paulo: Pontes/EDUC, 1991.

DESCARTES, R. Discurso do Método (Discourse on the Method). Mem Martins: Edicção Europa-América, 1977.

GATTI, B. Os professores e suas identidades: o desvelamento de heterogeneidade. Cadernos de Pesquisa, São Paulo, n. 98, p. 85-86, ago. 1996. 
JOSSO, M. C. Experiências de vida e formação (Life experience in education). Lisboa: Editora Educa-Formação/Universidade de Lisboa, 2002.

MARTINS, L. C. P. Conflitos e contradições na formação de professores: um estudo das práticas discursivas da disciplina Pratica de Ensino de Língua Inglesa . Dissertação de Mestrado - UNICAMP ,1998.

MATEUS, E. F. Educação contemporânea e o desafio da formação continuada. In: GIMENEZ, T. (Ed.). Trajetórias na formação de professores de línguas. Londrina: Editora da Universidade Estadual de Londrina,2002. p. 3-14.

SILVA, T. T. A produção social da identidade e da diferença (The social production of identity and difference). In: SILVA, T. T. (Org..). Identidade e diferença: a perspectiva dos estudos culturais. Petrópolis: Editora Vozes, 2000. p. 73-102.

SOUZA, M. de. De como (des)colonizar corações e mentes ou modos de conhecer e de subjetivar nas práticas de produzir e disseminar o conhecimento (How to decoloniae minds and ways of knowing, how to produce and disseminate knowledge). In: CASSIANI, S. (Ed.). Lugares, sujeitos e conhecimentos. A prática docente universitária (Places, subjects and knowledge). Florianópolis, Editora da UFSC. 2008. p. 57-74.

TARDIF, Maurice. Saberes docentes e formação profissional. 7.ed. Trad. Francisco Pereira. Petrópolis, RJ: Vozes, 2002.

TELLES, J. A. A trajetória narrativa: histórias sobre a prática pedagógica e a formação do professor de línguas. In: GIMENEZ, T. (Ed.). Trajetórias na formação de professores de línguas (Language teachers education). Londrina: Editora da Universidade Estadual de Londrina, 2002.p. 15-38 



\section{APORTES TEÓRICOS PARA CONSTRUÇÃO DE UM CURRÍCULO RIZOMÁTICO NA FORMAÇÃO DE PROFESSORES}

Fernanda Borges de Andrade

Valéria Moreira Rezende

\section{Introdução}

Diante de mudanças generalizadas na sociedade que se refletem no sistema educacional, constata-se uma ânsia dos educadores por entender por que se tornou tão difícil educar atualmente. Em busca de uma resposta que não é encontrada na formação inicial e nem na prática docente, ocorre a procura por cursos de atualização, de especialização e até de pós-graduação. Entretanto, temos observado que a frustração é comum. Na maioria das vezes, neles somente são oferecidas receitas técnicas desvinculadas do contexto de atuação do professor na sala de aula.

Sabemos que, embora a transformação objetiva nas condições das escolas não dependa apenas da atuação dos profissionais da educação, por outro lado, se não houver uma profunda mudança na concepção do trabalho docente, a transformação não poderá ocorrer. É necessário construir um novo sentido para a profissão, a fim de vencer o vazio, a perplexidade, a crise profissional e propor mudanças nas instituições educacionais - que ainda hoje são utilizadas para produção de "corpos dóceis" e eficientes por meio de mecanismos que conformam o espírito e estão tão introjetados na cultura institucional que sequer são percebidos pela maioria de seus professores e gestores.

O momento histórico das disciplinas é o momento em que nasce uma arte do corpo humano, que visa não unicamente o aumento das suas habilidades, mas a formação de uma relação que no mesmo mecanismo o torna tanto mais obediente quanto mais útil é. Forma-se então, 
uma política de coerções que consiste num trabalho sobre o corpo, numa manipulação calculada dos seus elementos, dos seus gestos, dos seus comportamentos. $\mathrm{O}$ corpo humano entra numa maquinaria de poder que o esquadrinha, o desarticula e o recompõe. A disciplina fabrica assim corpos submissos e exercitados, os chamados "corpos dóceis". A disciplina aumenta as forças do corpo (em termos econômicos de utilidade) e diminui essas mesmas forças, ela dissocia o poder do corpo, faz dele por um lado uma "aptidão", uma “capacidade" que ela procura aumentar; e inverte por outro lado a energia, a potência que poderia resultar disso e faz dela uma relação de sujeição estrita (Foucault, 1997, p. 119).

Essa situação colocada por Foucault é ainda mais grave na "sociedade de controle" anunciada por Deleuze (1996), onde os espaços de aprendizagem são enormemente ampliados pela tecnologia da informação e comunicação.

As sociedades disciplinares são aquilo que estamos deixando para trás, o que já não somos. Estamos entrando nas sociedades de controles, que funcionam não mais por confinamento, mas por controle contínuo e comunicação instantânea. (Deleuze, 1996, p. 220)

São formas de "controle" que levam à consolidação de um modelo de gerenciamento educacional por parte do Estado e que ocorre por meio de práticas pedagógicas e de manutenção do disciplinamento na escola, muitas vezes não percebidas como autoritárias e coercitivas, da mesma forma que ocorre na sociedade, como o modelo padronizante de comportamento social.

O professor sabe que deve deixar de ser mero transmissor de informações para mediar conhecimentos problematizando e aprendendo junto, exercendo sua função político-pedagógica diante de alunos que precisam construir e reconstruir conhecimento a partir do que fazem.

Esses são grandes desafios da profissão docente, que se desenvolveu enraizada na tradição do servir no interior das congregações religiosas 
e procura, na atualidade, descobrir seu próprio sentido social para, assim, obter meios de provocar o reconhecimento que a sua função exige. Diante de tal situação, ecoa em nós o depoimento emocionado de Paulo Freire, quando afirma que:

Como prática estritamente humana jamais pude entender a educação como uma experiência fria, sem alma, em que os sentimentos e as emoções, os desejos, os sonhos devessem ser reprimidos por uma espécie de ditadura reacionarista. Nem tampouco, jamais compreendi a prática educativa como uma experiência a que me faltasse rigor em que se gera a necessária disciplina intelectual (1987, p. 145).

Para que essa educação idealizada por Freire se torne realidade, se faz necessária uma sólida formação que permita a organização de uma prática pedagógica criativa e interdisciplinar, na qual se expressem os desejos coletivos do professor e de seus alunos. Uma formação que se contraponha à racionalidade técnica, que entenda o conhecimento como construção coletiva, temporal e sempre renovado. Afinal, os saberes que alicerçam o trabalho e a formação dos professores não podem ser separados das outras dimensões do ensino, nem do contexto do trabalho, da experiência de vida e da história da pessoa.

\section{Sala de aula universitária: espaço do encontro numa perspectiva rizomática}

Buscaremos aqui tratar da relação do professor e do aluno no processo de ensino aprendizagem. A primeira questão a ser considerada é que não há exclusividade e nem centralidade, seja no docente seja no discente, porque é necessário construir uma relação que permita a interação simultânea num espaço de diálogo consistente entre os envolvidos. O espaço da aula torna-se, pois, promotor da experiência do encontro, possibilitando o desenvolvimento mútuo, o diálogo, o conhecimento numa atividade coletiva. Nessa direção, teríamos um espaço de sala de aula na perspectiva rizomática, que tem como características a conexão e a heterogeneidade, já 
que qualquer ponto do rizoma pode e deve ser conectado a qualquer outro (Deleuze; Guattari, 1995).

Torna-se, assim, fundamental repensar o currículo dos cursos de licenciatura, os quais têm sido influenciados pelo conceito de ciência moderna, prescrito, linearizado e positivista, ao compartimentar as disciplinas oferecidas sem qualquer conexão entre si ou com outras áreas do conhecimento, num modelo de currículo que poderíamos classificar como currículo arbóreo, porque:

[...] ele é tomado como uma grande árvore, cujas extensas raízes devem estar fincadas em solo firme (as premissas verdadeiras), com um tronco sólido que se ramifica em galhos e mais galhos, estendendo-se assim pelos mais diversos aspectos da realidade. Embora seja uma metáfora botânica, o paradigma arborescente representa uma concepção mecânica do conhecimento e da realidade, reproduzindo a fragmentação cartesiana do saber resultado das concepções cientificas (Gallo, 2003, p. 88 e 89 , grifos do autor).

Nessa perspectiva, ao se utilizar o currículo "arbóreo", ratifica-se que a ciência cartesiana é a forma legítima de conhecimento e que o professor deve atuar como transmissor de saberes prescritos, e o aluno, por outro lado, deve apenas assimilar o que é transmitido. O currículo hierarquizado e compartimentado permanece estagnado, organizado como um grande eixo de onde partem normas do que se deve ensinar e de como se deve aprender. A imagem da árvore ilustra a estrutura clássica dos saberes e da ciência, que parte de uma base como unidade principal de pensamento que

[...] nunca compreendeu a multiplicidade: ele necessita de uma forte unidade principal, unidade que é suposta para chegar a duas [...] (três, quatro, cinco) mas sempre com a condição de dispor de uma forte unidade principal, a do pivô que suporta as raízes secundárias" (Deleuze; Guattari, 1995, p. 13).

Nesse tipo de pensamento arbóreo prevalece a lógica binária de que há um "tronco" que se desdobra em ramificações que não se relacionam 
umas com as outras, delimitando os campos da ciência. São sistemas hierárquicos nos quais um elemento recebe as informações e detém o poder como se fosse a memória central de onde partem todos os ramos e lógicas evolutivas do conhecimento, não havendo possibilidade de multiplicidade.

O que propomos, ao contrário, é vislumbrar a possiblidade de construção de um currículo-rizoma nos cursos de formação de professores, na esteira da perspectiva deleuziana. Um currículo que não se prenda a um núcleo, mas que possibilite a oferta de conexões para um ensino múltiplo e transdisciplinar, que pense a formação do futuro professor em vias de complexidade:

Diferentemente das árvores ou de suas raízes, o rizoma conecta um ponto qualquer com outro ponto qualquer, e cada um de seus traços não remete necessariamente a traços de mesma natureza, ele põe em jogo regimes de signos muito diferentes, inclusive estados de não-signos. O rizoma não se deixa reduzir nem ao Uno nem ao múltiplo... Ele não é feito de unidades, mas de dimensões, ou antes, de direções movediças. Não tem começo nem fim, mas sempre um meio pelo qual ele cresce e transborda. Ele constitui multiplicidades (Deleuze; Guattari, 1995, p. 31).

O atual estágio do conhecimento humano se adequa ao conceito de rizoma proposto por Deleuze e Guattari, que tem como características os princípios de conexão e de heterogeneidade, de forma que qualquer ponto do rizoma pode e deve ser conectado a outro. Mas o que seriam os rizomas? Rizomas são espécies de hastes ou caules subterrâneos que se diferenciam dos demais tipos de raízes por terem formas diversificadas. "Desde sua extensão superficial ramificada em todos os sentidos até suas concreções em bulbos e tubérculos [...] há o melhor e o pior no rizoma: a batata e a grama, a erva daninha" (Deleuze; Guattari, 1995, p. 15).

No rizoma não há um ponto central nem escalas de importância ou tipologia ideal; nele todos os tipos de associações são possíveis de ocorrer por meio das interações. Não há qualquer relação com o específico ou com 
o individual, já que a característica principal do rizoma é sua multiplicidade. "Uma multiplicidade não tem nem sujeito nem objeto, mas somente determinações, grandezas, dimensões que não podem crescer sem que se mude de natureza" (Deleuze; Guattari, 1995, p. 17). O rizoma possui linhas interconectadas, planas, que se inter-relacionam nas mais variadas possibilidades: "acontecimentos vividos, determinações históricas, conceitos pensados, indivíduos grupos e formações sociais" (Deleuze; Guattari, 1995, p. 18).

Outro princípio do rizoma que nos ajuda a problematizar a formação de professores é o de ruptura a-significante, ou seja, um conhecimento anteriormente considerado como "tronco" de uma ciência específica pode ser retomado em outra área, sendo ressignificado e conectado a outras concepções, satisfazendo novas necessidades de conceitualização importantes em um devido momento. Desse modo, conceitos oriundos de uma ciência exata podem ser ressignificados e utilizados em outros campos do conhecimento, como, por exemplo, na definição de comportamentos sociais e humanos no contexto atual. Dessa forma, o rizoma compreende "linhas de segmentaridade que os organizam, mas nele ocorrem também linhas de desterritorialização, pelas quais ele foge sem parar [...] essas linhas não param de se remeter umas às outras (Deleuze; Guattari, 1995, p. 18).

Os autores consideram como princípio de cartografia o fato de que "um rizoma não pode ser justificado por nenhum modelo estrutural ou gerativo. Ele é estranho a qualquer ideia de eixo genético ou de estrutura profunda" (Deleuze; Guattari, 1995, p. 21). Nessa ótica, a utilização do conceito de rizoma significa entender que as ciências não se limitam a "territórios" determinados, como se fossem estruturas arborescentes e hierárquicas. Em vez disso, percebe-se a impossibilidade de se fixar limites seguindo círculos de convergência, já que novos pontos se estabelecem dentro e fora desses círculos instituindo conexões em múltiplas outras direções.

O conceito é fecundo para conceber o currículo dos cursos de licenciatura como elemento produtor de movimentos numa multiplicidade (universidade, escola, alunos, professores, pais) que produz outras multiplicidades que o dinamizam. Nessa perspectiva, as disciplinas e especialidades se organizariam a partir das conexões, das relações e das 
variações, que possibilitassem sua integração, sem necessidade de haver um eixo organizador único a apontar direções a serem seguidas, mas sugerindo e abrindo possibilidades e caminhos conectados entre si.

Dessa forma, a aprendizagem se daria por meio de um tipo de pensamento que vai em busca do desconhecido, do que ainda não foi pensado para construir algo que possibilite enfrentar o problema que desassossega e afeta o sujeito, arremessando-o em um movimento de pensamento. Esse incômodo inicial seria o desencadeador cognitivo que levaria o licenciando ao desdobramento de possíveis soluções e aprendizagens, no diálogo com outros sujeitos, tendo em vista não ser a aprendizagem um caminho solitário, como adverte Deleuze (1998, p. 54): "nada aprendemos com aquele que nos diz: faça como eu. Nossos únicos mestres são aqueles que nos dizem 'faça comigo' e que, em vez de nos propor gestos a serem reproduzidos, sabem emitir signos a serem desenvolvidos no heterogêneo".

A perspectiva rizomática de estrutura do conhecimento no campo da formação de professores exige a compreensão de que existem várias formas de conhecimento que dialogam entre si e que estão inseridas em diferentes contextos histórico-sociais. Essa atitude e entendimento rompem com a rigidez e linearidade no trato com os conteúdos, uma vez que seus saberes criam ligações, conexões, com diferentes áreas do saber.

Torna-se, pois, necessário repensar os modos de se tratar os conteúdos e saberes do currículo dos cursos de formação de professores, para que os princípios de conexão e heterogeneidade demonstrem a complexidade e amplitude do conhecimento. Para tanto, tentamos organizar uma "matriz" curricular como um mapa rizomático, que possa promover a interação, complexidade e diversidade de saberes no processo de formação de professores.

\section{Organização curricular rizomática na formação de professores}

O processo formativo só tem razão de acontecer se tiver como objetivo a melhoria da qualidade de ensino por meio do aprimoramento profissional da categoria docente, combatendo a inadequação da formação inicial que, muitas vezes, apresenta-se falho na formação de professores 
capazes de responder aos inúmeros desafios da complexa sociedade do século XXI.

Afinal, a predominância de uma formação inicial fundamentada em um currículo arbóreo acaba gerando futuros professores que tenderão a realizar práticas fragmentadas, olhando o aluno/sujeito de suas práticas em partes, o que, dificilmente, dá espaço para a criação, ou ao estabelecimento de canais de comunicação com outros saberes, tornando difícil a recontextualização e as interconexões desses saberes.

A perspectiva que se apoia no conceito de rizoma (Deleuze; Guattari, 1995) parte de uma visão de realidades complexas e plurais - constituídas por múltiplas culturas e realidades sociais - que produzem desafios, que não podem ser abarcados por uma única disciplina ou área. Será necessário ir além dos saberes disciplinares, para que o pensamento e o conhecimento tenham oportunidade de se manifestar menos hierarquizados e não lineares.

Não será suficiente, pois, que se agreguem diferentes disciplinas ou conhecimentos, mas é necessária uma articulação de conhecimentos diversos que, ao se somarem e interagirem, possibilitem a construção de novos conhecimentos diferentes dos iniciais. Permite-se, dessa forma, promover mudanças nas relações entre sujeitos ao apostar na interlocução, na sua relação dialógica enriquecida pelas competências de cada um em diferentes campos do saber.

No rizoma, múltiplas são as linhas de fuga que possibilitam conexões, aproximações, cortes, percepções, criando fluxos de compreensão e concepções que tomam outra direção, sem necessidade de nenhuma hierarquia definida antecipadamente. "O rizoma conecta um ponto qualquer com outro ponto qualquer e cada um de seus traços não remete necessariamente a traços da mesma natureza; ele põe em jogo regimes de signos muito diferentes, inclusive estados de não signos" (Deleuze; Guattari, 1995, p. 32). Seu fundamento é a própria multiplicidade que "não deve designar uma combinação de múltiplo e uno, mas, pelo contrário, uma organização própria do múltiplo como tal, que de modo nenhum tem necessidade da unidade para formar um sistema" (Deleuze; Guattari, 1988, p. 303). 
É oportuno enumerar algumas características iniciais do rizoma, para posteriormente refletirmos sobre esse conceito em uma perspectiva mais ampla. Gallo (2000), com base na cartografia deleuziana, enumera seis princípios para a compreensão rizomática:

a) conexão - qualquer ponto de um rizoma pode ser/estar conectado a qualquer outro (...); b) heterogeneidade - dado que qualquer conexão é possível, o rizoma rege-se pela heterogeneidade (...); c) multiplicidade - o rizoma é sempre multiplicidade que não pode ser reduzida à unidade (...) o rizoma não é sujeito nem objeto, mas múltiplo; d) ruptura a-significante - o rizoma não pressupõe qualquer processo de significação, de hierarquização. (...) o rizoma é sempre um rascunho, um devir, uma cartografia a ser traçada sempre e novamente, a cada instante; e) cartografia - o rizoma pode ser mapeado, cartografado e tal cartografia nos mostra que ele possui entradas múltiplas; f) decalcomania - os mapas podem, no entanto, ser copiados, reproduzidos [o que não garante] uma sobreposição perfeita. [No entanto, o inverso,] colocar o mapa sobre as cópias, possibilita o surgimento de novos territórios, novas multiplicidades" (p. 31-32).

Nota-se, pois, que essa perspectiva rizomática apresenta-se como possibilidade de superar a linearidade curricular nos processos de formação de professores, trazendo outros entendimentos, outras relações e articulações, permitindo, assim, compreensões mais abrangentes dos conhecimentos demandados pela realidade contemporânea.

\section{Redesenhando possibilidades na proposição de um currículo rizomático}

Os desafios postos à consecução dessa proposta convidam todos os educadores a refletirem sobre a necessidade de se incluir temas que perpassem o processo de formação e de produção de conhecimentos, movimentando subjetividades que gerem compreensões amplas para quem vai lidar com a complexidade da realidade educacional. 
O estudo das Diretrizes Curriculares para o Ensino Superior deve possibilitar discussões que propiciem a oportunidade de revisão dos modelos curriculares que ainda se pautam na perspectiva padronizada, de disciplinas estanques e fragmentadas, que pouco têm colaborado para desenvolver práticas curriculares na perspectiva rizomática.

Com essa revisão, será possível propor um Projeto de Curso que estimule a vivência de outras relações dos licenciandos com a pesquisa e o ensino nos diferentes campos do conhecimento. O caminho, para tanto, são as discussões capazes de propiciar uma maior interação entre os professores, entre professores e alunos e entre alunos com outros alunos - inclusive de outros cursos.

O desenvolvimento de projetos educacionais que possibilitem a aproximação entre a universidade e a escola básica apresenta-se como possibilidade de construção de currículos alinhados com a proposição rizomática, na medida em que permitem a construção de espaços coletivos para estudos, pesquisas e reflexões sobre a prática pedagógica, envolvendo, dessa forma, diversos sujeitos que atuam em diferentes campos do fazer educacional, a partir das singularidades de cada um.

O Estágio Supervisionado poderá, também, se constituir num rico campo de pesquisa, caso seja capaz de promover mudanças no processo de trabalho pedagógico, ao propiciar a participação dos licenciandos nas atividades de docência. Esse processo deverá ser pensado para substituir o modelo predominantemente individual por outro que contemple também o trabalho coletivo na escola e em sala de aula, pelo desenvolvimento de trabalhos colaborativos.

Por ser o rizoma constituído de multiplicidades, conceber um currículo nessa perspectiva é concebê-lo sem objeto ou sujeito, sem direção determinada, visto como sendo produzido na e pela diversidade, ao envolver reitor, pró-reitores, diretores de instituto e departamentos, coordenadores pedagógicos, professores, alunos e comunidade que, embora sejam personagens com visões diferenciadas, tornam-se capazes de estabelecer conexões 
entre si, numa diversidade que leve em consideração o devir ${ }^{1}$, permanentemente instalado nos processos de ensino e de aprendizagem.

Ao apresentar as ideias aqui explicitadas, não pretendemos oferecer receitas prontas para a formação de professores. Trata-se de um convite para que outras vozes se somem, para enfrentarmos o desafio de repensar esse processo de outras perspectivas que possibilitem fazer delas um devir.

Essa proposta é na verdade uma ousadia, porque sugere um profundo repensar sobre a lógica que perpassa o ensino acadêmico tradicionalmente compartimentado e isolado. Não se trata, pois, de apresentar aqui um trabalho que possa ser considerado pronto, mas como algo que requer muitas entradas e outras reflexões que incitem o pensar sobre outros modos de construção curricular nos cursos de licenciaturas.

\section{Considerações finais}

A proposição de reflexões do conceito de rizoma teve como objetivo buscar a construção de pensamentos menos rígidos e a possibilidade de vislumbrar leveza e criação nos processos acadêmicos de formação de professores. O mapa de organização rizomático, como forma de construção de um currículo nos cursos de licenciatura, busca dar visibilidade à necessidade de ampliação e integração dos saberes e práticas.

A flexibilidade na organização rizomática do mapa na concepção das disciplinas ocorre porque a lógica que perpassa é a do planejamento pensado com base nas conexões entre os conhecimentos e sujeitos. Conexões essas que, a cada edição do curso, se transformarão em outras, proporcionando outras ações e aprendizagens.

É importante considerar que não se trata de propor um novo modismo em termos de currículo, e sim demonstrar aos futuros professores que a educação escolar não deve impor por quê e como ensinar, desconsiderando a

\footnotetext{
${ }^{1}$ Devir é um conceito filosófico que qualifica a mudança constante. $\mathrm{O}$ conceito tem lugar privilegiado na filosofia de Deleuze e Guattari que afirmam que todo pensamento é um devir. Devir e pensar se implicam na medida em que possibilitam sair do senso comum, desterritorializando o próprio pensamento. Desse modo, devir não é, ele acontece potencializando a criação de coisas novas, o que é imprescindível para superar os fenômenos de padronização e produzir modos de vida singulares (Deleuze; Guattari, 1997).
} 
realidade de quem vai aprender, e o que se vai ensinar, tendo em vista que se tornou impossível acompanhar a velocidade vertiginosa com que as informações circulam e se tornam obsoletas na atualidade.

A construção de outros modos e maneiras de se pensar a educação diz respeito às possibilidades de outras ensinagens e aprendizagens, pois como nos faz pensar Deleuze (1998, p. 270) "nunca se sabe de antemão como alguém vai aprender - que amores tornam alguém bom em latim, por meio de que encontros se é filósofo, em que dicionários se aprende a pensar (...) não há métodos para encontrar tesouros nem para aprender”.

\section{Referências}

DELEUZE, G. Post-scriptum sobre as sociedades de controle. In: Conversações. Tradução de Peter Pál Pelbart. SP: Editora 34, 1996.

DELEUZE, G. Diferença e repetição, Rio de Janeiro: Graal, 1998.

DELEUZE, G; GUATTARI, F. Mil platôs. Capitalismo e esquizofrenia. São Paulo, Edit. 34, 1995.v.1, 95p.

DELEUZE, G; GUATTARI, F Mil platôs. Capitalismo e esquizofrenia. São Paulo, Edit. 34, 1997.v.4, 176p.

FOUCAULT, M. Resumo dos cursos do Collège de France (1970-1982). Rio de Janeiro: Jorge Zahar Ed.,1997.

FREIRE, Paulo. Pedagogia do oprimido. São Paulo: Paz e Terra, 1978.

GALLO, Silvio. Deleuze e a Educação. Rio de Janeiro: Autêntica, 2003. 


\section{FORMAÇÃO CONTINUADA NA EDUCAC̄̃O INFANTIL E SUAS CONTRIBUIÇÕES PARA A CONSTRUÇÃO DA IDENTIDADE PROFISSIONAL}

Andréa Rodrigues de Souza

José Carlos de Melo

\section{Introdução}

Atualmente, a sociedade exige uma educação que seja comprometida com as mudanças sociais envidadas por meio das constantes transformações no cenário político e econômico. No que se refere à Educação Infantil, observa-se que um dos maiores debates para a promoção de uma educação não assistencialista e não compensatória gira em torno da construção do próprio conceito de criança e infância, assim como a formação inicial/continuada do educador(a) de crianças pequenas, em especial as mulheres, que durante muitos anos exerceram um papel extremamente feminino e não profissional, sob a égide de uma educação assistencialista.

Diante do exposto, observa-se que as concepções que têm norteado o trabalho com as crianças de 0 a 3 anos, nas creches, e das crianças de 4 a 5 anos, nas pré-escolas, têm revelado as marcas de um cuidar e educar baseadas em ideários espontaneístas que enfatizam a passividade e a obediência das crianças perante o mundo (Arce; Martins, 2007).

A superação dessa lógica põe em evidência desafios a serem enfrentados. Dentre eles, ressalta-se a formação inicial e continuada de professores para além das práticas referenciadas na obviedade, as quais obstaculizam o exercício das habilidades, capacidades e aptidões infantis.

Com efeito, o papel do professor na Educação Infantil ganha especial relevo quando adequado às especificidades do desenvolvimento das crianças, o que exige a apropriação e objetivação do legado da humanidade, expresso nas contribuições das várias ciências. 
O presente artigo é fruto de uma pesquisa realizada acerca do processo de formação continuada desenvolvido em dois cursos de formação para os professores de Educação Infantil de uma rede pública municipal. $O$ primeiro foi o Curso de Especialização em Docência na Educação Infantil (CEDEI), seguido do Curso de Extensão em Docência em Educação Infantil (CEEI), realizados em uma parceria entre o Ministério da Educação (MEC), uma Universidade Federal e uma Rede Pública Municipal de Educação.

Quanto ao objetivo, essa pesquisa classifica-se como exploratória que, de acordo com Gil (1999, p. 43), visa proporcionar ao pesquisador uma visão geral de um determinado fato. Optou-se, ainda, pela abordagem do tipo qualitativa que, de acordo com Minayo (2001), trabalha com o universo de significados, valores, aspirações, atitudes, preocupando-se com os aspectos da realidade estudada, concentrando-se na explicação das dinâmicas sociais e não na quantificação de dados. Os instrumentos de coleta de dados foram a observação não participante e a análise documental dos trabalhos e pesquisas acerca dos referidos cursos.

Este trabalho está assim constituído: na primeira parte, tem-se um breve histórico sobre a implementação da Educação no Brasil, bem como a inserção da mulher no magistério. Na segunda parte, foi abordada a definição de alguns conceitos referentes à Educação Infantil e sua implementação no contexto brasileiro.

$\mathrm{Na}$ terceira parte, foi discutida a necessidade da formação continuada para os profissionais que atuam na Educação Infantil e o processo de construção/fortalecimento da sua identidade profissional. Foram abordadas, ainda, com uma breve descrição, as ações realizadas pelo CEDEI e CEEI. Por fim, têm-se as considerações finais, nas quais os autores se posicionam acerca da referida temática.

\section{Breve percurso da educação brasileira}

Sabe-se que a educação brasileira teve seu início no ano de 1549, com a chegada dos padres jesuítas, que trouxeram consigo uma metodologia baseada no disciplinamento do corpo, na ordem e na disciplina, tendo como 
premissa os mecanismos sociais como o vigiar e o punir (Foucault, 2005). Dessa forma, observa-se que, durante o processo de colonização, o objetivo dos jesuítas não era o de promover uma educação para as crianças indígenas, mas iniciar o processo de aculturação desses povos (Lopes, 1991).

Com a vinda da família real para o Brasil, houve uma evolução no que diz respeito à educação e à cultura, pois nesse período surgiram algumas instituições científicas, culturais e de ensino técnico, além da implantação dos primeiros cursos superiores, no ano de 1808, a exemplo do curso de medicina nos estados do Rio de Janeiro e São Paulo (FÁVERO, 2000).

De acordo com Louro (1997), o período que compreende a proclamação da Independência no ano de 1822 e a instituição da República em 1889, o governo brasileiro necessitou realizar algumas mudanças no sistema educacional, uma vez que a nação estava vivendo um crescente processo de transformação e modernização.

Nesse sentido, a educação constituiu-se como uma ferramenta importante para que o País se desenvolvesse enquanto nação e se livrasse do estereótipo de país colonizado. Fez-se necessário, portanto, "investir" na criação das chamadas Escolas de Primeiras Letras para atender esse objetivo.

Destaca-se que, além da criação dessas escolas, fez-se necessário investir na formação de professores para atuar,sobretudo no Ensino Primário, a exemplo da criação das Escolas Normais, como será demonstrado a seguir.

\section{A criação das Escolas Normais e a feminização do magistério}

A primeira Escola Normal do País foi criada no ano de 1835, na Província do Rio de Janeiro, capital do Brasil na ocasião, por meio da Lei $\mathrm{n}^{\circ} 10$ de 1835. A referida lei determinava a criação de uma escola para habilitação de profissionais que se destinariam ao exercício do magistério na instrução primária. Para ter acesso à matrícula, o candidato ${ }^{2}$ necessitava,

\footnotetext{
${ }^{2}$ De acordo com Almeida (1998), a Escola Normal, por ocasião da sua instituição, só admitia homens, situação que foi revertida alguns anos depois, pois as mulheres começaram a adentrar esses espaços.
} 
como pré-requisito para ingressar, ser cidadão brasileiro, ter 18 anos de idade, bom testemunho e moral, além de saber ler, escrever e contar (MELLO, 1985).

É válido afirmar que a Escola Normal foi a princípio uma instituição de caráter precário, uma vez que não existia a preocupação e nem o interesse por parte dos governantes em investir em uma boa formação para os futuros professores, mas, sim, corresponder ao processo de expansão do Ensino Primário, necessário para o fortalecimento do País enquanto Estado.

O público inicialmente atendido por essas instituições era majoritariamente composto por homens. Com o decorrer dos anos, as Escolas Normais passaram a admitir as mulheres, todavia, havia diferenciação no currículo, uma vez que o público feminino possuía no seu currículo disciplinas como português, francês, história, geografia, aritmética, música e pedagogia. Havia, ainda, disciplinas voltadas para a aprendizagem de prendas domésticas para as alunas. Em relação ao currículo masculino, além das disciplinas mencionadas (com exceção de prendas domésticas), os alunos aprendiam geometria, que era uma disciplina vetada para as mulheres (LOURO, 2007).

Segundo Louro (2007), embora, na época da sua instituição, a Escola Normal admitisse somente homens, no decorrer dos anos, o que se viu foi o ingresso maciço de mulheres não apenas nos cursos de magistério, como também nas salas de aulas. Esse fenômeno pode ser explicado por dois fatores em especial. O primeiro foi o processo de migração masculina ${ }^{3}$ para outras profissões, em virtude dos baixos salários. O segundo foi o remanejamento da mulher para servir de mão de obra barata para o magistério, uma vez que essa profissão possibilitava à mulher conciliar o trabalho com sua função de esposa/mãe.

Diante do exposto, pode-se inferir que a atividade docente passou a ser associada às características consideradas tipicamente femininas, a

\footnotetext{
${ }^{3} \mathrm{~A}$ feminização do magistério deveu-se em parte ao processo de urbanização e industrialização, do final do século XIX e início do século XX, que absorveu a mão de obra masculina em outros setores, dentre eles a indústria, motivada pela oferta de empregos mais rentáveis.
} 
exemplo da paciência, do cuidado, da afetividade, entre outras. Tais características, associadas ao ideário religioso da época, tiveram como principais consequências a visão da docência como "sacerdócio" e não como profissão. Esse aspecto repercute ainda na atualidade e constitui-se como um dos principais motivos pelos quais a docência se tornou uma profissão pouco valorizada, e com uma formação insuficiente para o exercício da sua atividade docente, sobretudo nas instituições de Educação Infantil e Anos Iniciais.

\section{A Educação Infantil no contexto brasileiro: primeiras aproximações}

A implementação de um modelo de assistência, bem como a preocupação com a infância no Brasil, data do final do século XIX, com a criação das "Rodas dos Expostos", que eram locais reservados para acolher as crianças abandonadas por suas mães. Nesse período surgiram as primeiras leis de amparo às crianças, visto que até então todos os cuidados ficavam ao encargo da família.

De acordo com Ariès (1981), na Idade Média não havia o sentimento de infância, e o autor destaca que essa categoria é uma invenção da Modernidade. Assim sendo, observa-se que esse sentimento surgiu em consequência de um processo histórico, durante o qual a criança começou a ser vista como um ser social.

Já Kuhlmann Jr. (1998) afirma que a infância possui um significado genérico, que se dá em função das transformações sociais ocorridas no decorrer dos anos.

Após o surgimento da Roda dos Expostos, tem-se a instituição das Creches e Pré-escolas. De acordo com Kuhlmann Jr. (1998), o processo de implantação das creches no Brasil foi marcado pelo assistencialismo, pois o objetivo de seus idealizadores era apenas promover o cuidado básico para com as crianças. Já em relação aos denominados "Jardins de Infância", o autor destaca que a primeira instituição a ser fundada no País nasceu da iniciativa privada, no ano de 1875, na cidade do Rio de Janeiro: trata-se do Colégio Menezes de Vieira, que atendia aos filhos da elite fluminense. 
$\mathrm{O}$ autor destaca, também, que o governo inaugurou a primeira instituição de Educação Infantil pública no ano de 1896, na cidade de São Paulo, 26 anos após a instituição do Colégio Menezes de Vieira no Rio de Janeiro. Esse Jardim de Infância funcionava anexo à Escola Caetano de Campos e, apesar de ser uma instituição de ordem pública, também atendia aos filhos das elites paulistas (Kuhlmann Jr., 1998).

Diante do exposto, observa-se que o processo de implementação da Educação Infantil no Brasil ocorreu sob o prisma do assistencialismo para as creches e da chamada educação por excelência para os Jardins de Infância, além da segregação social, uma vez que as elites tinham acesso às vagas das instituições públicas, a exemplo do que ocorria no colégio Caetano de Campos.

No final do século XX, mais precisamente no ano de 1988, com a promulgação da Constituição Brasileira, também conhecida como Constituição Cidadã, a educação das crianças pequenas passou a ser considerada um direito do cidadão e uma obrigação do Estado. Destaca-se que, nesse contexto, a criança passou a ser vista como um sujeito de direitos.

No ano de 1990 foi criado o Estatuto da Criança e do Adolescente, que ratificou o direito da criança a ter uma educação pública e gratuita. Em relação à inserção da Educação Infantil no sistema educacional brasileiro, nota-se que ela só foi oficializada após a promulgação da Lei de Diretrizes e Bases (LDB) no ano de 1996:

A educação infantil, primeira etapa da educação básica, tem como finalidade o desenvolvimento integral da criança até cinco anos de idade, em seus aspectos físicos, psicológicos, intelectual e social, complementando a ação da família e da comunidade (Brasil, 1996, p.10).

Nos anos posteriores, foram criados outros dispositivos legais que visaram nortear as práticas educacionais nas Instituições de Educação Infantil, a exemplo do Referencial Curricular Nacional para a Educação Infantil (RCNEI), em 1998, das Diretrizes Curriculares Nacionais para a Educação Infantil (DCNEI), no ano de 2009, além da atual Base Nacional 
Comum Curricular (BNCC), que estabelece cinco campos de experiência no âmbito dos quais são definidos os objetivos de aprendizagem e desenvolvimento infantil. Esses campos constituem um arranjo curricular do que está presente no cotidiano da criança, entrelaçando-o aos conhecimentos historicamente construídos (BRASIL, 2017).

Nesse sentido, faz-se necessário investir não somente em uma legislação específica para atender às necessidades da criança, como também na formação inicial/continuada dos profissionais que atuam na referida etapa, como será abordado a seguir.

\section{Formação continuada de professores na Educação Infantil e sua identidade profissional}

O processo de formação de professores é constituído pela formação inicial e formação continuada. Acerca dos conceitos e concepções dessas formações, Gomes (2013, p. 68) afirma que "formação continuada" é oriundo do entendimento de educação permanente. Informa também que a expressão surgiu na Europa com a necessidade dos países do pós-guerra em superar os limites da educação formal.

Ao tratar da temática formação de professores, em especial do processo de formação continuada dos profissionais que atuam na Educação Infantil, percebe-se que os professores que trabalhavam com a Educação Infantil tiveram suas primeiras indicações da formação adequada, após a promulgação da LDB. Até então, a maioria das pessoas que estavam no exercício do Magistério não possuía uma formação específica para atuar na docência. Essa falta de formação foi reconhecida na ocasião da promulgação da LDB, no artigo 62:

A formação de docentes para atuar na educação básica far-se-á em nível superior, em curso de licenciatura, de graduação plena, em universidades e institutos superiores de educação, admitida, como formação mínima para o exercício do magistério na Educação Infantil e nos 5 (cinco) primeiros anos do ensino fundamental, a oferecida em nível médio na modalidade normal (BRASIL, 1996, p. 21). 
Assim sendo, destaca-se que o processo de formação continuada se constitui como um dos principais instrumentos para que haja mudanças significativas no atual contexto educacional brasileiro, considerando a importância da formação teórica para que os professores consigam atender melhor às necessidades educacionais de seus alunos. A formação teórica deve estar aliada tanto ao processo de formação inicial quanto às condições de trabalho dignas, para que todos possam desenvolver suas capacidades.

Já a formação da identidade profissional ocorre mediante um processo constante de construção e desconstrução que o sujeito histórico, político e social estabelece com ele próprio, com o desenvolvimento profissional e com o Outro, exigindo sempre uma ação direta dos elementos do grupo profissional em um processo de permanente relação com as diversas condições históricas, sociais, políticas, culturais e organizacionais, ou seja, a construção da identidade profissional corresponde a um processo inter e intrapessoal (Sarmento, 2009).

De acordo com Nóvoa (1995), a identidade profissional está intrinsecamente ligada à identidade pessoal, incluindo suas crenças, valores e projetos de vida. Para o autor, a identidade profissional não pode estar desassociada da identidade pessoal, uma vez que ambas se constituem como elementos importantes quando se trata da formação docente, uma vez que seus reflexos se manifestam na qualidade do trabalho docente.

Autores como Schön (1995), Pimenta (1999), Sarmento (2009) dentre outros enfatizam a importância da formação continuada no processo de construção/fortalecimento da identidade profissional do educador de crianças pequenas, bem como a necessidade de esse(a) profissional refletir acerca da sua prática, mas para que isso ocorra é necessário que haja uma reflexão, análise e problematização sobre sua própria prática, ou seja, que haja um equilíbrio entre a ação e o pensamento (Melo; Souza, 2017).

Dessa forma, torna-se necessário refletir sobre a construção da identidade profissional, bem como sobre a importância de o professor (a) estar sempre se atualizando, tendo em vista que o processo de formação continuada deve promover ao profissional a apropriação de saberes, objetivando levá-lo a apresentar algumas características, como o desenvolvimento da 
autonomia, e a refletir sobre sua ação no cotidiano, examinando suas práticas e agindo sobre elas, não como um reprodutor de ideologias, mas sim como um ser livre, capaz de tomar suas próprias decisões (Pimenta, 1999).

\section{Sobre a necessidade de se formar professores de Educação Infantil na região pesquisada: algumas considerações}

Incialmente, destaca-se que, na cidade e Estado onde a pesquisa foi realizada, o processo de formação docente realizado nas Escolas Normais iniciou no ano de 1838, quando o jovem Felipe Benício Oliveira Conduru foi escolhido e enviado para a França, onde estudou e, posteriormente, quando retornou ao seu lugar de origem e desenvolveu o método de Lancaster em diversas províncias do seu Estado (Oliveira, 2004).

Em relação ao surgimento do curso de Pedagogia no local pesquisado, destaca-se que este foi inaugurado na universidade na qual foi realizada a pesquisa, sendo o primeiro a ser fundado no Estado, no ano de 1953, e efetivado e reconhecido três anos mais tarde, por meio do Decreto No 39.663 de 28 de julho de 1956. Atualmente, ele é ofertado em dois turnos (vespertino e noturno), sendo responsável pela formação inicial de muitas professoras(es). Constata-se, hoje, a existência de outros cursos de Pedagogia em muitas universidades, tanto públicas quanto particulares, nas quais são formados(as) professores(as) que atuam nas escolas de Educação Infantil (Dias, 2002).

A respeito do processo de formação continuada dos profissionais que atuam na Educação Infantil, pode-se afirmar que atualmente ele ocorre de várias maneiras, dentre elas, destacam-se as formações ofertadas no âmbito da Secretaria Municipal de Educação-SEMED, que ocorrem por meio de ações educativas voltadas para os professores e gestores das escolas municipais, além dos encontros formativos que ocorrem nas escolas.

Entretanto, mesmo com a implementação de vários cursos de formação continuada nas universidades públicas e privadas, a ênfase sobre a necessidade de se compreender melhor as necessidades da Educação Infantil era muito grande. Dessa forma, a necessidade de atenção levou os 
professores do curso de Pedagogia da universidade onde foi feita a pesquisa ao Governo, para buscarem novas estratégias para a melhoria da formação dos docentes que atuavam na Educação Infantil.

Assim sendo, surgiram oportunidades de se desenvolver algumas ações implementadas por meio da SEMED e do Ministério da Educação e Cultura - MEC/SEB, em parceria com a Universidade, através de algumas ações formativas, a exemplo do Curso de Especialização em Docência na Educação Infantil-CEDEI, e do Curso de Extensão em Docência em Educação Infantil-CEEI, voltados para a formação de professores da infância. Tais ações são provenientes de uma política macro de formação nacional e foram as primeiras realizadas em âmbito de políticas de formação para os educadores de crianças pequenas.

A seguir, serão abordados os trabalhos desenvolvidos pelos cursos no local da pesquisa.

\section{A contribuição do CEDEI no processo de formação continuada das profissionais da E.I.}

O CEDEI é uma das ações desenvolvidas pelo Núcleo de Educação e Infância de uma Universidade Federal. O referido núcleo foi instituído no dia 26 de maio de 2011 pela resolução 841- CONSEPE, estando vinculado administrativamente ao Curso de Pedagogia, Departamentos de Educação I e II e ao Programa de Pós-Graduação em Educação-PPGE e do Programa de Pós-Graduação em Gestão do Ensino da Educação Básica-PPGEEB da referida universidade, definindo-se por sua natureza como multidisciplinar e interinstitucional. O Núcleo funciona em uma sala localizada no primeiro andar na Asa Norte do Centro Pedagógico Paulo Freire, localizado nas instalações da Universidade.

O CEDEI teve como objetivo geral formar, em nível de Pós-Graduação, professores, coordenadores e diretores de creches e pré-escolas de uma rede pública do município, assim como colaborar com a formação dos professores de educação infantil em nível de Estado. Em relação ao CEDEI, sua equipe foi composta por uma Coordenadora Geral e um 
Coordenador adjunto, ambos auxiliados por uma supervisora e duas agentes administrativas.

O início das atividades da primeira turma ${ }^{4}$ (2013/2015) ocorreu no segundo semestre do ano de 2013, após o processo seletivo que gerou a primeira turma composta por professoras e coordenadoras das Secretarias de Educação do município pesquisado e demais adjacências, sendo finalizadas no mês de fevereiro de 2015, após as defesas dos trabalhos de conclusão de curso.

O curso da segunda turma do CEDEI iniciou no mês de agosto de 2015 e finalizou em janeiro de 2017, ressaltando-se ainda que, nessa segunda turma, houve a participação de professoras e gestoras de algumas escolas comunitárias conveniadas com o município (Souza, 2017).

$\mathrm{O}$ CEDEI foi realizado na modalidade presencial, com aulas às sextas-feiras à noite e aos sábados. $\mathrm{O}$ término das aulas teóricas ocorreu no $1^{\circ}$ semestre de 2016, especificamente no mês de junho, quando as alunas cursistas iniciaram o processo de elaboração de suas monografias, baseadas nas temáticas abordadas durante as aulas e orientadas pelos professores do curso.

O CEDEI teve ainda a colaboração de professores convidados de outras Universidades, no que tange à ministração de palestras, oficinas e elaboração de artigos para a produção de um livro que foi lançado no dia 20 de junho de 2015, intitulado: Reflexões E̋ Práticas na formação continuada de professores da Educação Infantil, reunindo uma coletânea de artigos escritos por autores renomados da área (Souza, 2015).

O Curso compreende uma matriz curricular própria, que tem como principal finalidade trazer assuntos relacionados à Educação Infantil e à formação de professores para atuarem nessa etapa de educação básica, buscando, em geral, a compreensão do objeto de estudo e trabalho desses profissionais: a criança e a infância.

\footnotetext{
${ }^{4}$ Até a presente data, o CEDEI ofertou duas turmas; a primeira é referente ao período de agosto de 2013 a fevereiro de 2015. Já a segunda turma compreende o período de setembro de 2015 a fevereiro de 2017.
} 
Além das disciplinas que compõem a matriz curricular do Curso, foi realizada uma aula inaugural e dois Seminários. O primeiro seminário teve a participação de alunos e professores do CEDEI, assim como demais profissionais da área da Educação Infantil, totalizando 150 participantes. Foi intitulado como I Seminário do CEDEI - a pesquisa na educação infantil: "imagens, tempos e espaços.

O evento ocorreu no mês de novembro de 2013, objetivando fomentar a pesquisa científica nas instituições de educação infantil para a formação de professoras-pesquisadores, uma vez que uma das barreiras nessa área tem sido o pragmatismo pedagógico, atrelado ao modelo educacional "escolarizante"

O segundo seminário, intitulado Pesquisas e oficinas na educação infantil: análise crítica da prática pedagógica, aconteceu no mês de dezembro de 2013, tendo como finalidade realizar atividades coletivas e multidisciplinares, enfocando temáticas na área da educação infantil, problematizando algumas questões relacionadas às práticas docentes, além de buscar estabelecer um diálogo com teóricos que estudam a educação infantil com as demais ciências.

Nesse seminário, teve-se a participação dos alunos e professores do CEDEI, totalizando 200 participantes, além da participação de alguns professores convidados de outras instituições de Educação Superior (UFU, UFRS, USP, PUC/SP, UFSCar, UFMS, UFRS, UEPG), que proferiram palestras e oficinas sobre temáticas voltadas à docência na educação infantil. Ambos os eventos possibilitaram um olhar mais aprofundado sobre o processo de formação continuada das alunas, uma vez que:

A formação continuada deveria apoiar, criar e potencializar uma reflexão real dos sujeitos sobre sua prática docente nas instituições educacionais e em outras instituições, de modo que lhes permitisse examinar

\footnotetext{
${ }^{5}$ Entende-se por modelo educacional escolarizante na Educação Infantil os resquícios das práticas tradicionais que persistem em conceber essa etapa da educação básica como preparação para o ingresso no Ensino Fundamental; em que se prioriza o processo de alfabetização em detrimento de outras atividades importantíssimas no processo de aprendizagem da criança a exemplo do brincar.
} 
suas teorias implícitas, seus esquemas de funcionamento, suas atitudes, etc., estabelecendo de forma firme um processo constante de autoavaliação do que se faz e por que se faz (Imbernón, 2010, p. 47).

Dessa forma, o CEDEI realizou diversas atividades que foram além das aulas de caráter teórico, visando contribuir para que a Educação Infantil da rede municipal de ensino pesquisada aperfeiçoe seus índices de qualidade, por meio da formação oferecida aos professores e demais profissionais da educação, proporcionando um processo de ação/reflexão/ação de suas práticas docentes.

Em relação à segunda turma do CEDEI, destaca-se que a aula inaugural foi realizada no dia 29 de setembro de 2015, no prédio do Serviço Social do Comércio- SESC/TURISMO, nos períodos matutino e vespertino. Essa aula inaugural teve como tema central "Culturas infantis e manifestações expressivas das crianças: um convite à professora e ao professor”, e, como palestrante, a Profa. Dra. Marcia Aparecida Gobbi, da Universidade de São Paulo-USP, que na ocasião discutiu sobre a temática refletindo, sobretudo, a respeito do cotidiano do professor da educação infantil, diante da sua realidade, bem como a necessidade de rever o seu processo criativo.

Além da aula inaugural e das aulas teóricas, o CEDEI realizou um Seminário, que teve a participação de alunas e professores, assim como os demais profissionais da área da Educação Infantil, que foi intitulado: III Seminário do CEDEI - a formação continuada de professores na educação infantil: diversos olhares, ocorrido entre os dias 4 e 5 do mês de dezembro de 2015, que, a exemplo dos seminários anteriores, teve a finalidade de fomentar a discussão sobre a temática nas instituições de educação infantil e sobre a formação de professoras-pesquisadores.

$\mathrm{Na}$ ocasião, foi realizado o lançamento de dois livros. $\mathrm{O}$ primeiro é referente ao trabalho desenvolvido na primeira turma do CEDEI, contendo uma coletânea dividida em dois volumes de artigos relativos às monografias das alunas da primeira turma de especialização do curso, intitulado: (Re) visitando as práticas das professoras da educação infantil na ilha 
do Maranhão. O segundo livro é referente ao trabalho desenvolvido pelo Curso de Extensão em Docência em Educação Infantil-CEEI, intitulado: A formação continuada de professores da educação infantil: distintas abordagens, contendo uma série de artigos de autores renomados na área da educação Infantil (Souza, 2017).

No dia 26 de novembro de 2016, nos períodos matutino e vespertino, foi realizado o I Seminário de Monografia do CEDEI, com as alunas e professores do curso, que funcionou como uma pré-qualificação das monografias, sendo que as defesas das mesmas foram realizadas entre as datas de 16/1 a 26/1/2017. A exemplo da primeira turma, foi lançado, no ano de 2017, um livro com uma coletânea de artigos dividida em dois volumes referentes às monografias do curso, intitulado: Educação infantil: escritos contemporâneos, e outro denominado Educação infantil: entrelaçamento de saberes (Souza, 2017).

\section{Educação Infantil e extensão universitária: CEEI e a formação docente}

Assim como o CEDEI, o Curso de Extensão em Docência em Educação Infantil-CEEI, é resultado de uma parceria firmada entre o MEC/ SEB e a Universidade. O curso objetivou formar em nível de extensão professores, coordenadores e gestores de creches e pré-escolas, que atuam da rede pública municipal pesquisada.

O curso foi organizado por uma equipe constituída por: uma coordenação geral, com a função de conservar a unidade do trabalho, valorizando a diversidade de saberes e experiências; e uma coordenação adjunta, com o papel de acompanhar o trabalho dos professores, supervisores e cursistas, bem como dos professores responsáveis pela produção das unidades temáticas e da coordenação do trabalho pedagógico no desenvolvimento das turmas (Colins, 2016).

Esse curso foi voltado para a formação continuada de professores da área de Educação Infantil, em nível de extensão, com vistas a contribuir com a formação dos educadores infantis. Teve por horizonte os 
"Fundamentos e Organização do Trabalho Docente na Educação Infantil”, visto que há uma urgência em se pensar os processos pedagógicos que levem em consideração as especificidades da educação infantil, conforme afirma Kramer (2006, p. 804):

A formação de profissionais da educação infantil - professores e gestores - é desafio que exige a ação conjunta das instâncias municipais, estaduais e federal. Esse desafio tem muitas facetas, necessidades e possibilidades, e atuação, tanto na formação continuada (em serviço ou em exercício, como se tem denominado a formação daqueles que já atuam como professores) quanto na formação inicial no ensino médio ou superior.

Segundo Colins (2016), a operacionalização do curso ficou sob o encargo do Núcleo de Educação e Infância da Universidade. A coordenação do curso ficou sob a responsabilidade de um Coordenador Geral e uma coordenadora adjunta, além de duas supervisoras pedagógicas, que atuaram nos cursos vespertino e noturno.

O CEEI foi realizado entre os meses de fevereiro de 2015 a julho de 2015. A aula inaugural aconteceu no dia 6 de março de 2015, no I Seminário do CEEI, intitulado: Formação continuada de professores da educação infantil: desafios contemporâneos, no Auditório Central da Universidade, contando com a participação de alunos e professores do CEEI, assim como os demais profissionais da área da Educação Infantil.

Conforme enfatiza Colins (2016), o objetivo do seminário era fazer que os docentes refletissem sobre seu processo de formação continuada e suas implicações para a construção da identidade e profissionalização do professor de Educação Infantil, com base em fundamentos teóricos críticos.

A conferência de abertura foi ministrada pela Profa. Dra. Denise Maria de Carvalho Lopes, da Universidade Federal do Rio Grande do Norte- UFRN. O evento teve ainda como palestrantes professoras da Universidade Federal do Sergipe-UFS; Universidade Estadual do Tocantins - UNITINS, e uma professora da Universidade local, que discorreram a respeito da formação continuada de professores e seus distintos olhares. 
Acerca do CEEI, pode-se informar que sua carga horária total contabiliza 180 horas, distribuídas em cinco unidades temáticas: 1- A Infância e a Educação Infantil no Contexto Histórico e Político; 2- Contribuições da Pedagogia, Psicologia, Sociologia e Antropologia para a compreensão da Infância; 3- A Educação infantil e Movimentos Sociais; 4- A Educação Infantil, Currículo, Inclusão e Diversidade; e, por último, 5- Formação, Identidade e Profissionalização do Docente da Educação Infantil (Colins, 2016).

O Seminário de encerramento do curso aconteceu no dia 13 de junho de 2015, intitulado: Formação continuada de professores: a dimensão histórica, velhos dilemas e perspectiva para o presente. $\mathrm{O}$ evento foi realizado no auditório do Centro Pedagógico Paulo Freire, com a presença do ilustre pesquisador Dr. Moysés Kuhlmann Jr., da Fundação Carlos Chagas e da Universidade Católica de Santos-UNISANTOS.

$\mathrm{O}$ evento contou também com a participação de professores da UNESP- São José do Rio Preto-SP, Universidade Federal de Uberlândia-UFU e de professores da Universidade local. Teve como principal objetivo a ampliação do conhecimento da educação infantil, a partir da sua dimensão histórica, compreendendo assim seus reflexos na formação profissional que atuam na referida etapa (Colins, 2016).

O Seminário marcou o encerramento das atividades da primeira turma do CEEI, que foram divididas em dois turnos (vespertino e noturno), ofertados na modalidade presencial, tendo um total de aproximadamente 50 concluintes, que defenderam seus trabalhos de conclusão de curso com a apresentação e defesa oral de um banner relacionado às temáticas estudadas em classe e orientadas por um professor(a).

\section{Considerações finais}

O processo de formação continuada deve ter como principal função promover aos profissionais da educação infantil uma reflexividade crítica sobre suas práticas e de (re) construção permanente de uma identidade pessoal e profissional em interação mútua. A formação continuada é parte 
integrante do processo de construção da identidade, do qual os saberes profissionais também fazem parte (Candau, 1996).

A construção da identidade do profissional, dos docentes que atuam na Educação Infantil, foi constituída por dois paradigmas: o primeiro baseado no modelo de educação assistencialista, em que o objetivo principal era o de promover os cuidados para com os pequenos; o segundo está voltado para a necessidade de se ter um profissional com formação adequada para trabalhar nessa faixa etária, tendo em vista que a Educação Infantil é hoje considerada a primeira etapa da educação básica.

Dessa forma, torna-se imprescindivel a participação desses(as) profissionais em formações que estimulem uma avaliação da sua prática, sendo esta resultado de um processo construtivo, uma vez que a construção da identidade docente nesse profissional é algo que perpassa as esferas pessoais e sociais dos indivíduos, sendo constantemente transformada.

O conhecimento obtido no processo de formação continuada, a exemplo do CEDEI/CEEI, interfere diretamente na perspectiva das práticas pedagógicas, na formação do educador pesquisador e no cotidiano escolar, bem como no processo de construçãolfortalecimento da identidade profissional, na busca de mudanças gradativas e permanentes no contexto educacional brasileiro, em especial na Educação Infantil.

\section{Referências}

ALMEIDA, Jane S. de. Mulher e educação: a paixão pelo possível. São Paulo: Ed. da Unesp, 1998.

ARCE, Alessandra; MARTINS, Lígia Márcia. Quem tem medo de ensinar na educação infantil? Em defesa do ato de ensinar. São Paulo: Alínea, 2007.

ARIÈS, P. História Social da criança e da família. Rio de Janeiro: LTC, 1981.

BRASIL. Constituição da República Federativa do Brasil. Brasília-DF, 1988.

BRASIL. Estatuto da Criança e do Adolescente. Lei n o 8.069, de 13 de junho de 1990. Brasília-DF, 1990.

BRASIL. Lei de Diretrizes e Bases da Educação Nacional. Brasília-DF, 1996. 
BRASIL. Ministério da Educação e do Desporto, Secretaria de Educação Fundamental. Referencial Curricular Nacional para a Educação Infantil. Brasília: MEC/SEF, 1998.

BRASIL. Ministério da Educação. Câmara da Educação Básica do Conselho Nacional de Educação. Resolução no 05, de 17 de dezembro de 2009. Diretrizes Curriculares Nacionais para a Educação Infantil. Brasília: MEC/SEF, 2009.

BRASIL. Ministério da Educação. Base Nacional Comum Curricular. Brasília: MEC, 2017. Disponível em:< http://basenacionalcomum.mec.gov.br/>. Acesso em: 10 ago. 2018.

CANDAU, Vera Maria. Formação Continuada: tendências atuais. In: REALI, Aline Maria de M. Rodrigues; MIZUKAMI, Maria da Graça N. Formação de Professores: tendências atuais. São Carlos, SP: EdUFSCar, 1996.

COLINS, Francinete Oliveira. Formação Continuada de professores na Educação Infantil: uma análise sobre o Curso de Extensão em Docência em Educação Infantil - CEEI/ UFMA. 95f. Monografia de conclusão do curso de Pedagogia, UFMA, São Luís-MA, 2016.

DIAS, Ilzeni Silva. O ensino profissional no Maranhão: uma retrospectiva histórica. In: CADERNOS DE PESQUISA/Pró-Reitoria de Pesquisa e Desenvolvimento Tecnológico da UFMA. São Luís-MA: Editora da Universidade Federal do Maranhão, 2002.

FÁVERO, Maria de Lourdes de A. Universidade do Brasil: das origens à construção. Rio de Janeiro: Editora UFRJ//INEP, 2000.

FOUCAULT, Michel. Vigiar e punir: nascimento da prisão. Trad. Raquel Ramalhete. 20. ed. Petrópolis: Vozes, 2005.

GIL, Antonio Carlos. Métodos e técnicas de pesquisa social. 4.ed. São Paulo: Atlas, 1999.

GOMES, Marineide de Oliveira. Formação de professores na educação infantil. 2. ed. -São Paulo, Cortez, 2013. (Coleção docência em formação. Série Educação Infantil).

IMBERNÓN, Francisco. Formação continuada de professores. Porto Alegre: Artmed, 2010 .

KRAMER, Sônia. As crianças de 0 a 6 anos nas políticas educacionais no Brasil: educação infantil e/é fundamental. Revista Educação \& Sociedade, Campinas, v. 27, n. 96 - Especial, p. 797-818, out. 2006.

KUHLMANN JR. M. Infância e educação infantil: uma abordagem histórica. Porto Alegre: Mediação, 1998.

LOPES, E. M. T. A Educação da mulher: a feminização do magistério. Teoria \& Educação, Porto Alegre, n.4, p.22-40, 1991. 
LOURO, Guacira Lopes. Mulheres na sala de aula. In: DEL PRIORE, Mary. História das Mulheres no Brasil. São Paulo: Contexto, 2007. p. 443-481.

LOURO, Guacira Lopes. Gênero e Magistério: identidade, história, representação. In: CATANI, Denise Barbara et al. (Orgs.). Docência, memória e gênero: estudos sobre formação. São Paulo: Escrituras Editora, 1997.

MELLO, Guiomar Namo de. A formação do professor das quatro primeiras séries do primeiro grau: sua evolução histórica e articulação com as mudanças ocorridas na escola elementar. Relatório de pesquisa. São Paulo: Fundação Carlos Chagas, 4 v. 1985.

MELO, José Carlos de; SOUZA, Andréa Rodrigues de. Como se constrói a identidade de professores na Educação Infantil. In: Revista humanidades. UNITINS, Palmas, abr./jun. 2017.

MINAYO, M. C. S. (Org.). Pesquisa social: teoria, método e criatividade. Petrópolis: Vozes, 2001.

NÓVOA, Antonio (Org.). Vidas de professores. 2. ed. Porto: Porto, 1995.

OLIVEIRA, Rosângela Silva. Do contexto histórico às ideias pedagógicas predominantes na escola normal maranhense e no processo de formação das normalistas na primeira república. 2004. Dissertação (Mestrado em Educação) - Universidade Federal do Maranhão, São Luís-MA, 2004.

PIMENTA, Selma Garrido (Org.). Saberes pedagógicos e atividade docente. São Paulo: Cortez, 1999.

SARMENTO, Teresa. As identidades profissionais em educação de infância. In: Locus SOCI@L.n. 2, 2009. p. 46-64.

SCHÖN, Donald. Formar professores como profissionais reflexivos. In: NÓVOA, António (Org.). Profissão Professor. 2 ed. Porto Codex - Portugal: LDA, 1995.

SOUZA, Andréa Rodrigues de. A construção da Identidade docente das professoras ingressas na segunda turma do CEDEI. 2017. 94f. Monografia de conclusão de Pós-Graduação em Docência na Educação Infantil. UFMA, São Luís- MA, 2017.

SOUZA, Andréa Rodrigues de. Formação de professores na Educação Infantil: um olhar sobre a formação continuada das professoras ingressantes na primeira turma do CEDEI. 2015. 106f. Monografia de conclusão do curso de Pedagogia, UFMA, São Luís-MA, 2015. 



\title{
4. A FORMAÇÃO DO PROFESSOR NO CONTEXTO DA INCLUŞ̃̃O
}

\author{
Elizabeth Regina Streisky de Farias \\ Leociléa Aparecida Vieira
}

\section{Primeiras aproximações...}

A discussão sobre a formação de professores tem sido tema recorrente em diversos períodos da história, porém, os objetivos dessa formação se alteram de acordo com o contexto histórico, social e político. Se, nos séculos XVII a XVIII, o foco era uma educação elitista, com vistas à minoria abastada da população, a partir do século XIX já se vislumbra a preocupação de formar docentes que fossem capazes de combater o fracasso e o abandono escolar.

Mais recentemente, avançamos para uma preocupação com os aspectos inclusivos no processo de escolarização, portanto, não era mais suficiente garantir que alguns alunos aprendessem, mas sim que a aprendizagem deve estar acessível a todos que adentram o sistema escolar, independentemente de sua condição ou características.

Nesse sentido, discutir a formação de professores na perspectiva inclusiva significa repensar o papel social da escola, bem como o papel das instâncias formadoras na promoção social do indivíduo.

Este estudo voltou-se para a formação de professores e a inclusão escolar, com uma perspectiva emancipatória, compreendendo que quanto mais autônomo e emancipado o indivíduo se tornar, mais capaz será de refletir sobre as mazelas sociais e de realizar intervenções críticas na sociedade.

Salienta-se que, por tratar-se de um trabalho de cunho exploratório, optou-se por uma pesquisa documental, que contribuísse para a reflexão das políticas educacionais voltadas à formação e inclusão, por meio dos 
documentos norteadores oficiais, como também pela pesquisa bibliográfica que identificasse os estudos relevantes de autores que discutem a temática, como: Nóvoa (1992), Adorno (1995), Saviani (2009), Pimenta (2007) e Bueno (2005).

\section{O contexto histórico da formação de professores}

Os dados históricos nos permitem assegurar que a política educacional em nosso País sempre foi carente de ações que contribuíssem para a melhoria da escola, reconhecendo o protagonismo do professor como sujeito da história e importante nos processos decisórios da escola.

De acordo com Duarte (1986), já no século XVII reconhecia-se a importância da formação docente, no combate à falta de instrução da população e à falta de professores que organizassem esse trabalho. Nessa perspectiva, no século XIX, em vários países da Europa bem como nos Estados Unidos, tem início a criação de Escolas Normais que se encarregariam de preparar professores.

Essas escolas tinham como objetivo formar professores para o ensino secundário, porém, transformaram-se em escolas de auto estudos, sem preocupação com os aspectos didático-pedagógicos (Saviani, 2009).

No Brasil, as práticas docentes iniciaram-se em 1549, com a vinda dos padres jesuítas. Gomes et al. (2004, p.145) mencionam que "essas práticas revelam influências da pedagogia tradicional, como suporte do modelo da formação religiosa, no qual o professor - centro das ações pedagógicas - era reconhecido como 'o detentor do saber".

Segundo Tanuri (2000), antes que se fundassem as primeiras instituições destinadas a formar professores para as escolas primárias, já existiam preocupações no sentido de selecioná-los. Por exemplo, em 1827 foi promulgada uma lei que mandou criar escolas de primeiras letras em todas as cidades, vilas e lugares mais populosos do Império, e que também estabeleceu exames de seleção para mestres e mestras. Os candidatos que não tivessem necessária instrução, iam instruir-se em curto prazo - e à custa de seus ordenados - nas escolas da Capital. Em 1834, acontece a 
reforma institucional com o estabelecimento das primeiras escolas normais provinciais e, no ano seguinte, em 1835, foi implantada a primeira escola normal brasileira criada na província do Rio de Janeiro. Posteriormente, foram criadas outras escolas normais, mas somente a partir de 1870 é que elas começaram a ter algum êxito, quando se consolidam as ideias liberais de democratização e obrigatoriedade de instrução primária, bem como de liberdade de ensino.

Desde as primeiras tentativas, até os dias de hoje, identifica-se como grande problema da formação de professores a dissociação entre a forma e conteúdo, ou seja, aspectos didáticos e pedagógicos ou aspectos cognitivos. Saviani (2008) vislumbra que a saída possível é a articulação entre os dois aspectos.

Ao dar um salto de alguns anos e chegarmos ao século XX, especificamente por volta de 1920, as escolas normais já haviam ampliado a duração e o nível dos seus estudos. Escola nova, ensino ativo, método analítico, testes e medidas são palavras-chave da época.

Com o movimento da Escola Nova ${ }^{1}$, na década de 1930, os programas de ensino tornam-se mais flexíveis, adaptados ao desenvolvimento e à individualidade da criança; ocorreu uma inversão dos papéis do professor e do aluno, ou seja, a educação é percebida como resultado das experiências e atividades do aluno, sob o acompanhamento do professor; emergiu um ensino ativo em oposição a um criticado "verbalismo" da escola tradicional.

Perambulando pelo tempo, chegamos em 1964. Ano em que o país fica sob o domínio da ditadura militar. $\mathrm{Na}$ educação, impera a racionalidade técnica, a eficiência e a produtividade, e nesse clima é promulgada a Lei de Diretrizes e Bases da Educação (LDB) n. 5.692/71. Essa Lei adota

\footnotetext{
${ }^{1}$ A Escola Nova, também conhecida por Escola Progressista, foi um movimento de renovação de ensino proposto, no final do século XIX, por educadores europeus e norte-americanos em oposição ao ensino tradicional. O escolanovismo buscava a modernização, a industrialização, a urbanização e a democratização da sociedade. As ideias desse movimento no Brasil foram fortemente influenciadas pelo filósofo e educador americano John Dewey e, apesar de ter sido inserida no País por Rui Barbosa, em 1882, atingiu seu ápice em 1932, após a divulgação do documento Manifesto dos Pioneiros da Educação. Esse documento foi elaborado por um grupo de educadores liderados por Anísio Teixeira e Lourenço Filho e defendia a universalização da escola pública, gratuita e laica.
} 
um esquema integrado, flexível e progressivo de formação de professores e enfatiza a formação técnico-profissional, tendo como consequência, nos cursos de formação docente, a "licenciatura curta", cuja finalidade era preparar professores de maneira rápida e maciça (formação técnico-especialista). Gomes et al. (2004, p.146) explicitam que "a predominância dos aspectos produtivos e do fazer acontecer preponderaram sobre o pensar, analisar, refletir".

O debate sobre a formação de professores intensificou-se na década de 1980, período em que o cenário das práticas é mobilizado pelo surgimento das teorias críticas, surgindo uma concepção mais dialética, plural, crítica e interativa, tendo como pano de fundo a práxis.

$\mathrm{Na}$ década de 1990 eclodiu o movimento de valorização do processo identitário da profissão docente. A discussão do assunto acentuou-se com a aprovação da Lei e Diretrizes da Base Nacional (LDBEN) n. 9394/96, no dia 20 de dezembro de 1996, superando a polêmica relativa ao nível de formação - médio ou superior. Essa discussão elevou a formação do professor dos anos iniciais ao nível superior, estabelecendo que ela se desse em universidades e em institutos superiores de educação, nas licenciaturas e em cursos normais superiores. A referida Lei estabelece no seu artigo 62 que “a formação de docentes para atuar na educação básica far-se-á em nível superior, em curso de licenciatura, de graduação plena, em universidades e institutos superiores de educação [...]” (BRASIL, 2006).

Neste início do século XXI, marcado por mudanças profundas na sociedade humana, tem sido questionado o modelo de professores caracterizado pela racionalidade técnica. Segundo Mizukami et al. (2002), nesse contexto, põe-se em discussão a hegemonia da ciência moderna. Refuta-se a concepção positivista como único paradigma de conhecimento. Rejeita-se a separação entre sujeito e objeto no processo de conhecer. Questiona-se o papel da técnica como aplicação exclusiva da teoria na intervenção da realidade. Inseridas nesse contexto e por ele determinadas, mas sobre ele exercendo sua influência, a educação em geral e a escola em particular refletem as transformações em curso. As realidades sociais, econômicas, políticas e culturais das diversas sociedades humanas passam a exigir, da 
escola, mudanças em seus projetos educativos, para atender às demandas de formação de uma nova cidadania, sob a ótica da justiça e da superação das desigualdades sociais.

O papel profissional do professor e sua formação sofrem o impacto dessas demandas. Amplia-se e aprofunda-se a discussão. Intensifica-se a refutação do modelo racionalista técnico dominante, por não responder às necessidades emergentes da sociedade e da escola em transformação. Avança-se na formulação de propostas de mudança que apontam na direção de uma racionalidade prática na formação e na ação docente do educador.

O exposto até aqui pode ser sintetizado com as palavras de Saviani (2009, p. 143-144), para quem as primeiras iniciativas para as mudanças na educação no país, a partir da independência, ocorreram nos seguintes períodos:

- Ensaios intermitentes de formação de professores (1827-1890). Esse período se inicia com o dispositivo da Lei das Escolas de Primeiras Letras, que obrigava os professores a se instruir no método do ensino mútuo, às próprias expensas; estende-se até 1890, quando prevalece o modelo das Escolas Normais.

- Estabelecimento e expansão do padrão das Escolas Normais (1890-1932), cujo marco inicial é a reforma paulista da Escola Normal tendo como anexo a escola modelo.

- Organização dos Institutos de Educação (1932-1939), cujos marcos são as reformas de Anísio Teixeira no Distrito Federal, em 1932, e de Fernando de Azevedo em São Paulo, em 1933.

- Organização e implantação dos Cursos de Pedagogia e de Licenciatura e consolidação do modelo das Escolas Normais (1939-1971).

- Substituição da Escola Normal pela Habilitação Específica de Magistério (1971-1996).

- Advento dos Institutos Superiores de Educação, Escolas Normais Superiores e o novo perfil do Curso de Pedagogia (1996-2006).

Mizukami et al. (2002), refletindo sobre o movimento em curso no Brasil, destacam que - no âmbito das políticas públicas para a educação 
básica, o processo de desvalorização da formação inicial realizada, historicamente, em cursos de nível médio para atuação nos anos iniciais do ensino fundamental e, no nível superior, em cursos de licenciatura - os investimentos na formação de professores vêm sendo deslocados para momentos posteriores à formação inicial.

Por meio de ações de curta duração, que têm assumido as denominações de "capacitação em serviço", "treinamento em serviço", "formação continuada" e outros, esse modelo fundamenta-se, predominantemente, na racionalidade técnica. Decorre da concepção tradicional e conservadora de educação, inspirada no paradigma positivista, que supervaloriza os conteúdos e suas técnicas de transmissão, reduzindo o papel da educação escolar à mera instrumentação técnica.

Sem dúvida, o desafio da formação de professores, de forma coerente e articulada, persiste ao longo do tempo, comprometendo o enfrentamento ao fracasso escolar e à busca da qualidade na educação, porém, o desafio torna-se maior quando tratamos da formação docente para atuar na Educação Especial, tendo em vista as dúvidas ainda existentes quanto ao encaminhamento.

Apesar de a legislação brasileira reconhecer a importância dessa formação, a resolução do Conselho Nacional de Educação (2006), que definiu as Diretrizes Curriculares Nacionais para o Curso de Pedagogia, aborda a questão da Educação Especial apenas duas vezes, conforme indica o Artigo $5^{\circ}$., inciso X: “[...] demonstrar consciência da diversidade, respeitando as diferenças de natureza ambiental-ecológica, étnico-racial, de gêneros, faixas geracionais, classes sociais, religiões, necessidades especiais, escolhas sexuais, entre outras". O Artigo $8^{\circ}$, no inciso III trata:

[...] atividades complementares envolvendo [...] opcionalmente, a educação de pessoas com necessidades especiais, a educação do campo, a educação indígena, a educação em remanescentes de quilombos, em organizações não governamentais, escolares e não-escolares, públicas e privadas. 
Tais dispositivos indicam o papel secundário desempenhado pela Educação Especial na legislação brasileira quanto à formação de professores, deixando uma lacuna com relação à formação necessária para atuar nessa modalidade de Ensino.

Porém, a Resolução no. 02, de 2015, do Conselho Nacional de Educação, que define as Diretrizes Curriculares Nacionais para a formação inicial em nível superior e para a formação continuada, identifica os profissionais público-alvo da formação, conforme aponta o Art. $3^{\circ}$., parágrafo 4:

Os profissionais do magistério da educação básica compreendem aqueles que exercem atividades de docência e demais atividades pedagógicas, incluindo a gestão educacional dos sistemas de ensino e das unidades escolares de educação básica, nas diversas etapas e modalidades de educação (educação infantil, ensino fundamental, ensino médio, educação de jovens e adultos, educação especial, educação profissional e técnica de nível médio, educação escolar indígena, educação do campo, educação escolar quilombola e educação à distância), e possuem formação mínima exigida pela legislação federal das Diretrizes e Bases da Educação Nacional (BRASIL, 2015).

O encaminhamento apontado na referida resolução indica a preocupação com um processo inclusivo, conforme Art. $5^{\circ}$., item 2:

A formação dos profissionais do magistério (formadores e estudantes) como compromisso com projeto social, político e ético que contribua para a consolidação de uma nação soberana, democrática, justa, inclusiva e que promova a emancipação dos indivíduos e grupos sociais, atenta ao reconhecimento e à valorização da diversidade e, portanto, contrária a toda forma de discriminação (BRASIL, 2015).

Nessa perspectiva, os cursos de licenciatura passaram a incluir em seus currículos disciplinas voltadas à inclusão, porém, é importante ressaltar que não adianta incluir, nos currículos de cursos de formação de professores, disciplinas que permitam o atendimento de pessoas com deficiência, pois a eterna indefinição quanto a sua formação, aliada a fatores macrossociais e 
de políticas educacionais, tende a formar professores não preparados para atuar com alunos sem deficiência e que, portanto, apresentam mais dificuldades na atuação com alunos com deficiência.

Reconhece-se, portanto, que é preciso uma política educacional, que se volte para o combate ao fracasso escolar e à exclusão, garantindo que a inclusão aconteça não somente pelo acesso, mas também pela permanência e aprendizagem de todos.

Importante ressaltar que, para uma formação docente consistente e efetiva, é preciso que se leve em consideração a prática concreta da escola, como parte da prática social mais ampla, para que, em um processo de reflexão-ação, busque-se excluir ações excludentes, que perpetuam o fracasso e abandono escolar. Considera-se, portanto, que professores bem formados contribuem para o respeito e vivência da diversidade, bem como para práticas mais inclusivas.

Assim, refletir sobre a formação na perspectiva inclusiva implica refletir sobre a relação existente entre o processo de formação e prática do professor.

\section{A formação de professores para a inclusão}

O desafio de garantir educação de qualidade a todos envolve a reflexão sobre a formação docente na perspectiva da inclusão, sobre a dinâmica social e a articulação existente entre a formação e a prática do professor.

Contudo, não é possível tratar de questões relacionadas à formação de professores, sem discutir as lutas de classes e rupturas atreladas ao trabalho docente. Esses movimentos deram origem à construção de uma escola que privilegia as diferenças existentes no contexto escolar (Baptista, 2004).

Bueno (2005) assinala que o processo formativo ainda se constitui como um campo de embates. $\mathrm{O}$ autor afirma ainda que esse processo tem sido limitado pelas condições de trabalho e, embora a legislação privilegie uma política de formação docente voltadas à inclusão, a realidade ainda está distante dos índices mínimos para a consolidação da inclusão. 
A política de formação de professores no Brasil tem destinado aos estados e municípios as ações referentes à inclusão, o que nem sempre se concretiza na íntegra, já que muitas vezes esses entes federados não têm uma política de financiamento de educação compatível com as necessidades na área.

Nessa sociedade diversa, com distintas realidades sociais, originárias de um contexto social excludente, é um grande desafio a construção de uma sociedade que respeita e dialoga com a diversidade e se propõe democrática (Martins, 2002).

Nesse contexto, o papel do professor é decisório, na medida em que ele se propõe a aprofundar os conhecimentos teóricos e a refletir sobre e na ação, em busca da reconstrução de seus saberes e de intervenções que assegurem a inclusão dos indivíduos (Silva, 2014).

Considerar a inclusão um princípio educativo envolve acreditar que ela deve envolver todos os setores da escola e não se restringir ao espaço da sala de aula. Essa é uma tarefa coletiva e não somente do professor.

Porém, há que se considerar que a escola é o reflexo de uma sociedade excludente e que, portanto, é preciso um trabalho efetivo e abrangente, que dialogue com a comunidade, contribuindo, assim, com uma mudança não só no contexto escolar, mas também na sociedade.

O processo de formação de professores é de extrema relevância, tendo em vista o protagonismo do professor nas ações que executa e nos valores nos quais as pautam. Nesse sentido, torna-se essencial um olhar sobre a diversidade. Não se trata de conhecer todas as especificidades dos comprometimentos dos alunos, mas direcionar o olhar para a compreensão da diversidade, respeitando as necessidades individuais, o que precisa ser o cerne da formação docente. Nesse sentido, o bom desempenho docente implica na capacidade de "problematizar a própria prática, refletindo criticamente a respeito dela" (Santos, 2007, p.15). Nessa esteira de pensamento, Feldmann (2003, p. 149) menciona que

[...] o professor do século XXI necessita mudar sua postura perante o conhecimento. De pretenso dono do saber, o educador passa a ser um 
mediador entre o conhecimento sistematizado e as necessidades dos alunos, na possibilidade de ampliar e diversificar formas de interagir e compartilhar experiências em novos tempos e espaços.

O professor deve lembrar que não sabe tudo e que, a cada dia, tem a oportunidade de estar aprendendo também. Ao acreditar que é o único detentor de todo o conhecimento, estreita e limita seu foco e, consequentemente, o de seus alunos. Assim, uma qualidade é essencial ao educador: a humildade em reconhecer suas limitações e sua "ignorância". Segundo Popper (1982, p. 57),

[...] quanto mais aprendemos sobre o mundo, quanto mais profundo nosso conhecimento, mais específico, consciente e articulado será nosso conhecimento do que ignoramos - o conhecimento da nossa ignorância. Essa, de fato, é a principal fonte de nossa ignorância: o fato de que nosso conhecimento só pode ser finito, mas nossa ignorância deve necessariamente ser infinita.

Necessário se faz, portanto, que o professor ressignifique sua prática docente, combatendo a exclusão e garantindo a aprendizagem de todos os alunos, o que será possível com um planejamento pedagógico que tenha como ponto de partida a realidade do aluno.

Nesse sentido, concorda-se com Nóvoa (1992), na afirmação de que o professor se qualifica na medida em que fortalece a qualidade do atendimento aos alunos e na crença de que os professores podem construir novas alternativas para que a aprendizagem dos alunos se efetive.

Alarcão (2001) reflete sobre o novo papel que os professores desempenham como atores sociais, autônomos, críticos e exigentes em sua profissionalidade docente.

A construção da autonomia do indivíduo, contudo, não tem sido priorizada nos cursos de formação de professores na atualidade. Isso pode ser atribuído, em grande parte, ao distanciamento entre a teoria aprendida na academia e a realidade da escola. 
Segundo Pimenta (2007, p. 16), na formação do professor prevalece “[...] um currículo formal com conteúdos e atividades de estágios distanciados da realidade das escolas, numa perspectiva burocrática e cartorial que não dá conta de captar as contradições presentes na prática social de educar $[\ldots]$ "..

As disciplinas nos currículos dos cursos de formação de professores não dialogam de modo especial, há pouca articulação entre as disciplinas de fundamentos e as disciplinas voltadas à prática. Esse modelo formativo não promove a construção da identidade docente que, por sua vez, não contribui para a melhoria da escola e da aprendizagem.

Nessa perspectiva, é possível afirmar que há um desafio a ser enfrentado, que diz respeito não só à formação inicial realizada na academia, mas diz respeito também às formas de organização escolar e ao estilo de gestão adotado.

O estilo de gestão, imposto por essa nova demanda da sociedade, diz respeito a uma liderança que mobilize e promova a cultura da participação de todos os envolvidos no processo educativo. É possível afirmar também que a construção de uma escola democrática, promotora da cultura da participação, requer também a construção da autonomia do indivíduo, a sua emancipação, para que essa mesma autonomia seja garantida no ambiente escolar.

Adorno (1995) assevera que muitas vezes se acredita que se vive em uma democracia, porém, vive-se tutelado pelas decisões de uma minoria dominante. $\mathrm{O}$ autor afirma ainda que a democracia está fundamentada na construção de sujeitos autônomos, que tomam suas próprias decisões. Sem a autonomia, o que se presencia é a massificação, segundo a qual algumas pessoas pensam pela maioria. Esse movimento é chamado pelo autor de pseudodemocracia.

Nessa perspectiva, a formação do professor com vistas à inclusão rompe com paradigmas, com resistências ao novo e contribui na reflexão sobre a prática. Assim, a eliminação ou minimização do preconceito e da segregação é parte da construção de escolas voltadas para a emancipação e para a liberdade (Adorno, 1995). 
É importante ressaltar também que, enquanto a formação inicial se apresenta deficitária, por estar distanciada da realidade concreta, a formação continuada não pode ser vista como um remendo que vem para sanar as dificuldades da formação inicial. Ela precisa ser planejada com base na realidade vivenciada pelos professores, para que tenha a força de ajudar na reflexão sobre a prática docente e de transformar a lógica excludente da organização escolar.

A formação que se almeja para os professores na atualidade não é a que segrega professores da escola comum dos professores da Educação especial, já que se compreende que esse modelo de formação fragmenta a escola e perpetua a exclusão, mas sim uma formação inclusiva, na qual se reconhece que a formação deve ser construída nas academias a partir da realidade da escola, compreendendo a inclusão como princípio.

A organização da escola, na perspectiva inclusiva, precisa estar voltada para o rompimento com toda a prática que naturaliza a exclusão e o fracasso escolar, tornando evidente a ineficácia da escola. Essa organização escolar privilegia a formação profissional em serviço, pelos problemas pedagógicos surgidos no contexto escolar.

\section{Considerações finais}

Refletir sobre a formação de professores na perspectiva da inclusão implica em refletir sobre a lógica escolar que, em vários contextos históricos, tem se mostrado excludente e elitista. É necessário, portanto, que paradigmas sejam rompidos, no sentido de garantir que a formação, tanto a inicial quanto a continuada, seja pensada com base na realidade concreta da escola.

Nessa perspectiva, a formação de professores é um pilar relevante da inclusão, sendo necessário que se almeje o desenvolvimento da autonomia docente, que contribuirá para a construção do espírito crítico, estabelecendo caminhos para a educação para todos, e que garanta não só o acesso, mas a permanência com sucesso. 
Pelas palavras ditas ou pelas palavras que foram omitidas, faz-se educação. A escolha do que ensinar e/ou do que não ensinar caracteriza as crenças e valores daqueles que são responsáveis pela formação direta do aluno. Estar preparado para essas escolhas também é um aspecto da formação.

\section{Referências}

ADORNO, T. W. Educação e emancipação. São Paulo: Paz e Terra, 1995.

ALARCÃO, I. Escola reflexiva e nova racionalidade. Porto Alegre: Artmed, 2001.

BAPTISTA, C. R. Ciclos de formação, educação especial e inclusão: frágeis conexões? In:

MOLL, Jaqueline (Org.). Ciclos na vida, tempos na escola: criando possibilidades. Porto Alegre: Artmed, 2004.

BAPTISTA, C. R. Escolarização e deficiência: configurações na política de inclusão escolar. São Carlos: Marquezine \& Manzini, 2015.

BATISTA, C.A.M. Políticas Sociais, Organizações da Sociedade Civil e o Processo de Inclusão das Pessoas com Deficiência no Brasil. In:TEODÓSIO, A. S. S. et al. Gestão Inclusiva: primeiro, segundo e terceiro setor. Belo Horizonte: Armazém de Ideias, 2003. p. 9-27.

BATISTA, M.W.; EMUNO, S.R.F. Inclusão escolar e deficiência mental: análise de interação social entre companheiros. Estudos de Psicologia, 2004.

BRASIL. Ministério da Educação. Lei no 9394/96. Lei de Diretrizes e Bases da Educação Nacional. Diário Oficial da República Federativa do Brasil, Brasília, 1996.

BRASIL. Ministério da Educação. LDB: Lei de Diretrizes e Bases da Educação Nacional: Lei n. 9.394, de 1996. Brasília: Senado Federal, Secretaria Especial de Editoração e Publicação, 1997.

BRASIL. Ministério da Educação. Conselho Nacional de Educação. Câmara de Educação Básica. Parecer CNE/CEB no 13/2009. Diretrizes Operacionais para o Atendimento Educacional Especializado na Educação Básica, modalidade Educação Especial. Brasília, DF, 2009. Disponível em: <http://portal.mec.gov.br/ dmdocuments/pceb013_09_ homolog. pdf $>$. Acesso em: 10 set. 2015.

BRASIL. Ministério da Educação. Conselho Nacional de Educação. Câmara de Educação Básica Parecer CNE/CEB n. 07/2010. Diretrizes Curriculares Nacionais Gerais para a Educação Básica. Brasília, 2010. Disponível em: <http://pactoensinomedio.mec.gov.br/images/pdf/pceb007_10.pdf>. Acesso em: 10 maio 2016.

BRASIL. Resolução CNE/CEB 04 de 02 de outubro de 2009. Institui Diretrizes Operacionais para o Atendimento Educacional Especializado na Educação Básica, modalidade 
educação especial. Brasília, DF, 2009. Disponível em: <http://portal.mec.gov.br/dmdocuments/rceb004_09.pdf>. Acesso em: 10 maio 2016.

BRASIL. Resolução CNE/CP n. 01 de 15 de maio de 2016. Institui Diretrizes Curriculares Nacionais para o Curso de Graduação em Pedagogia, licenciatura. Brasília, 2006. Disponível em: <http://portal.mec.gov.br/cne/arquivos/pdf/rcp01_06.pdf>. Acesso em: 15 jul. 2016.

BRASIL. A educação especial na sociedade moderna: integração, segregação do aluno diferente. São Paulo: Educ, 1993.

BUENO, J. G. S. A Educação Especial nas universidades brasileiras. Brasília, Ministério da Educação, Secretaria de Educação Especial, 2002.

DUARTE, N. As pedagogias do aprender a aprender e algumas ilusões da assim chamada sociedade do conhecimento. Revista Brasileira de Educação, n. 18, set./ dez. 2001.

FELDMANN, Marina Graziela. Questões contemporâneas: mundo do trabalho e democratização do conhecimento. In: SEVERINO, Antônio Joaquim; FAZENDA, Ivani Catarina Arantes (Org.). Políticas Educacionais: o ensino nacional em questão. Campinas: Papirus, 2003..

FAZENDA, Ivani Catarina Arantes (Orgs.). Políticas educacionais: o ensino nacional em questão. Campinas: Papirus, 2003. p. 127-150

GOMES, Heloisa Maria; ALVES, Leonir Pessate; FELDMANN, Marina Graziela; D’AGUA, Solange Vera Nunes de Lima; VEIGA, Windsor Espnser; MARIM, Wlademir. Formação docente e as mudanças na sala de aula: um diálogo complexo. Olhar de Professor, Ponta Grossa, v. 7, n. 2, p. 13-158, 2004.

MIZUKAMI, Maria da Graça Nicoletti et al. Formação de professores: concepção e problemática atual. In: Escola e aprendizagem da docência: processos de investigação e formação. São Carlos: EduFScar, 2002. p. 11-45.

NÓVOA, A. Formação de professores e profissão docente. In: (Org.). Os professores e sua formação. Lisboa: Nova Enciclopédia, 1992. p. 97-121.

PIMENTA, S. G. Saberes pedagógicos e atividade docente. 5. ed. São Paulo: Cortez, 2007.

POPPER, Karl Raymond. Conjecturas e refutações. Brasília: UnB, 1982.

SANTOS, M. P. Culturas, políticas e práticas de inclusão em universidades. Rio de Janeiro: UFRJ, 2007.

SANTOS, V. Paraná desafia MEC em política de inclusão. Gazeta do Povo, Curitiba, 24 de maio de 2010. Disponível em: <http://www.gazetadopovo.com.br/ensino>. Acesso em: 4 dez. 2015. 
SAVIANI, D. Formação de professores: aspectos históricos e teóricos do problema no contexto brasileiro. Revista Brasileira de Educação, v.14, n. 40, jan./abr., 2009.

TANURI, Leonor Maria. História da formação de professores. In: SAVIANI, Dermeval; CUNHA, Luiz Antônio; CARVALHO, Marta Maria Chagas de. Revista Brasileira de Educação: 500 Anos de Educação Escolar. São Paulo: Autores Associados, 2000.p. 61 - 88. 



\section{TECNOLOGIAS EMERGENTES E FORMAÇÃO DE PROFESSORES: O QUE AS GRADES CURRICULARES DE CURSOS DE PEDAGOGA SINALIZAM?}

Rafael Fonseca de Castro

\section{Introdução}

O presente artigo objetiva contribuir com o debate acerca da presença das tecnologias emergentes na formação inicial de professores. Diante da franca expansão de tecnologias digitais comunicacionais móveis, típicas do século XXI, torna-se imperativo problematizar sobre a constituição dos cursos de formação de professores para a prática docente em meio a este contexto atual de forte incidência dessas tecnologias no cotidiano social.

Mediante o estabelecimento de relações entre as grades curriculares dos cursos de Pedagogia das sete universidades federais das capitais dos estados da Região Norte do Brasil (UFAC, UFAM, UFPA, UFRR, UFT, UNIFAP e UNIR) e perspectivas pedagógicas contemporâneas, como educação híbrida, o uso educacional de tecnologias móveis e aprendizagem ubíqua apresenta discussões e indica questionamentos considerados fundamentais para pensar uma formação de professores sintonizada com o uso dessas tecnologias no dia-a-dia de universitários (futuros professores) e escolares da Educação Básica (alunos dos professores que estamos formando).

Para este estudo, são incorporadas publicações recentes sobre a relação entre educação e tecnologia para consubstanciar a hipótese de que, tanto os cursos de formação de professores, como as práticas escolares, de forma geral, enfrentam dificuldades para incorporar as tecnologias emergentes como mediadores (Vygotski, 1931/1995) dos processos de ensino, mesmo esses instrumentos já sendo utilizados em grande escala 
nas práticas e relações sociais da população brasileira. Diante desse cenário antagônico, cabe questionar: quantas e quais são as disciplinas voltadas ao uso educacional das tecnologias emergentes no currículo dos cursos de Pedagogia? Qual a carga horária total dessas disciplinas nesses currículos? Com que intensidade o uso dessas tecnologias é incentivado e efetivamente trabalhado pelos acadêmicos de Pedagogia ao longo do curso? A "cultura tecnológica" está incorporada no percurso da formação docente?

Não se pretende esgotar todas essas questões, mas estabelecer esse diálogo necessário, apresentando elementos que acentuem o debate dessa problemática. Para tal, o texto está organizado da seguinte forma: após esta introdução, abre-se espaço para o conceito de mediação na perspectiva vygotskiana; na sequência, são apresentadas perspectivas educacionais contemporâneas, a partir dos conceitos de educação híbrida, tecnologias móveis e aprendizado ubíquo, defendendo-os como possíveis instrumentos de mediação pedagógica atraentes aos estudantes (universitários e escolares); adiante, é aberta a discussão acerca da presença e da intensidade das tecnologias emergentes como mediadoras dos processos de ensino em disciplinas e grades curriculares dos cursos de Pedagogia das universidades federais das sete capitais da Região Norte do Brasil; as considerações finais encerram o artigo - mas não o debate! - de forma a relacionar os conceitos e as discussões levantadas, destacando questionamentos considerados fundamentais para suscitar e aprofundar o diálogo sobre a temática aqui empreendida.

\section{Mediadores pedagógicos na perspectiva Histórico-Cultural}

Os pressupostos teórico-metodológicos vinculados à $\mathrm{CHAT}^{1}$ têm embasado um grande número de pesquisas, em especial, nas áreas da Psicologia e da Educação. Sua riqueza conceitual permite o desenvolvimento

\footnotetext{
${ }^{1}$ Segundo o Center for Activity Theory and Developmental Work Research, da Universidade de Helsinki (http://www.edu.helsinki.fi/activity/pages/chatanddwr/chat/), esta denominação vem sendo usada, na atualidade, para designar o conjunto de ideias desenvolvidas pelo grupo de psicólogos russos revolucionários, que iniciaram sua atuação nos anos 1920 e 1930, sob a liderança de Lev Vygotsky.
} 
de teorias e práticas educacionais nos mais variados níveis e contextos, do oriente ao ocidente - como é possível verificar na coletânea internacional de Selau e Castro (2015).

Lev Semenovich Vygotsky (1896-1934) é o principal expoente dessa perspectiva, e o conceito de mediação é um dos mais referenciados em sua obra. Castro (2014) explica que, na perspectiva vygotskiana de formação social da mente (Vygotski, 1931/1995; Vygotsky, 1934/1982), toda a relação do ser humano com o mundo, no plano psíquico superior, é mediada. Ao contrário dos outros animais, que se relacionam diretamente com a natureza e entre si (relação com o mundo baseada em instintos e na resolução de problemas imediatos somente em planos de ação concretos), os seres humanos, ao desenvolver ferramentas e signos, alteram a natureza e passam a se relacionar também de forma mediada com o mundo e com os outros seres humanos.

Castro (2014) destaca o esquema proposto por Vygotsky que, apresentado na forma de um triângulo (conforme ilustra a Figura 1), ajuda a compreender o conceito de mediação, na perspectiva de formação social da mente:

Figura 1 - Triângulo de mediação

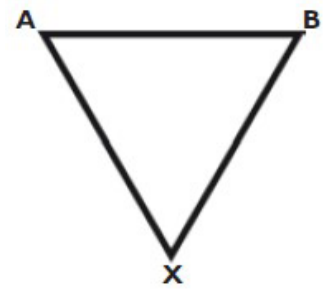

Fonte: (Vygotski, 1931/1995, p. 116)

De forma bastante simples, Vygotski (1931/1995) explicava que o processo de relação de A (sujeito) com B (ambiente) é mediado por X, onde $\mathrm{X}$ é o instrumento ( signo ou ferramenta) que propicia a atividade mediadora.

Freitas (2004) salienta que o conceito de mediação se interliga a toda a rede de conceitos de Vygotsky, principalmente no que se refere à 
compreensão de sujeito que, situado histórica e culturalmente, interage no mundo de forma mediada por instrumentos e signos. $\mathrm{O}$ conceito de mediação proposto por Vygotski (1931/1995) abre caminho, dessa forma, para uma compreensão de aprendizagem como um processo não determinista.

Daniels (2003) e Freitas (2004) argumentam que, no campo educacional, pode-se considerar que um livro, uma revista, uma imagem, uma obra de arte, um jogo, um computador ou uma tecnologia do nosso cotidiano operem como instrumentos mediadores de ensino e, consequentemente, de aprendizagem(ns). Obviamente, a efetiva contribuição de qualquer um desses (ou de outros) instrumentos e signos dependerá do uso que se fará deles, em uma situação educacional específica. Freitas (2004) e Castro (2014) salientam que a noção que se tem sobre mediação também inclui a mediação humana, assim como Vygotsky (1934/1982) se referia sobre a importância do professor no processo de aprendizagem, especificamente sobre a presença da pessoa mais experiente auxiliando no desenvolvimento da menos experiente - teoria expressa no conceito de Zona de Desenvolvimento Proximal (Daniels, 2003; Prestes, 2010; Castro, 2014).

As tecnologias emergentes como mediadoras na Educação vêm se constituindo em temas de inúmeras pesquisas no Brasil e no exterior como as de Souabni et al. (2016), Lucena (2016), Castro e Damiani (2011), Santana et al. (2006) e Palloff e Pratt (2002), só para citar algumas. Na literatura acadêmica, são defendidas como didáticas passíveis de inovação em escolas brasileiras e em diversos projetos educacionais pelo país. Além do potencial pedagógico que carregam, deve-se enfatizar que se trata de tecnologias que estão fortemente presentes no cotidiano das pessoas. Quantas pessoas que não possuem smartphone você conhece? Trata-se de uma grande inserção das tecnologias móveis na vida das pessoas, incluindo a de nossos estudantes (escolares e universitários). Os dispositivos móveis mudaram a forma dos relacionamentos com o mundo - atuando como ferramenta e com signos das múltiplas linguagens que utiliza na Atividade Mediadora. Trabalhar com objetos tão presentes no dia-a-dia na escola/ universidade é pensar a Educação a partir da realidade de seus aprendentes (FREIRE, 2011). 
No caso do presente estudo, questiona-se em que medida o estudo do uso pedagógico dessas tecnologias emergentes como mediadoras educacionais vem sendo discutido e pedagogizado na formação inicial de professores. Nas escolas ${ }^{2}$, tem sido perceptível tanto a carência de maior e melhor estrutura física e de equipamentos como lacunas na formação dos professores atuantes na Educação Básica. Obviamente, há escolas públicas bem estruturadas e experiências exitosas, contudo, em minha prática no dia-a-dia, seja nas supervisões de estágio em dezenas de escolas públicas de Porto Velho, seja no trabalho em projetos de pesquisa e extensão nesse mesmo rol de educandários municipais e estaduais, mesmo após iniciativas públicas e privadas, a regra está longe de ser escolas estruturadas e com docentes e demais funcionários efetivamente capacitados para incorporar as tecnologias emergentes como mediadores dos processos de ensino e de aprendizagem.

Optou-se, nesse sentido, por focalizar a formação inicial de professores. Afinal, se a constatação geral é de que os professores que estão atuando na Educação Básica e os projetos das escolas pouco ou nada incorporam pedagogicamente as tecnologias emergentes típicas do século XXI, torna-se imperativo questionar os processos formativos atuais - especificamente para a presente problematização, será analisado o currículo dos cursos de Pedagogia.

A seguir, são apresentadas perspectivas educacionais contemporâneas, com base nos conceitos de educação híbrida, aprendizado ubíquo e tecnologias móveis, defendendo-os como possíveis instrumentos de mediação pedagógica atrativos aos estudantes (universitários e escolares)

\section{Educação híbrida, tecnologias móveis e aprendizado ubíquo}

O conceito de tecnologias emergentes vem sendo utilizado na literatura acadêmica recentemente e foi adotado nos estudos vinculados ao

\footnotetext{
${ }^{2}$ As escolas mencionadas no texto são as públicas. Escolas privadas vêm incorporando as tecnologias emergentes como mediadoras de aprendizagem em maior escala do que as públicas. Contudo, estudos a elas direcionados também se fazem necessários.
} 
Grupo de Pesquisa "Hist-Cult - Educação, Psicologia Educacional e Processos Formativos" da Universidade Federal de Rondônia, principalmente, por seu caráter atemporal e por superar outras conceituações como Novas Tecnologias (NTIC), Tecnologias da Informação e da Comunicação (TIC) e Tecnologias Digitais Virtuais (TDV).

Uma tecnologia será emergente em seu tempo e será nova somente naquele tempo. Ao mesmo tempo, as tecnologias típicas da segunda década do século XXI possuem características que vão muito além de informar e comunicar. Os usuários de smartphones conectados podem realizar uma série quase inimaginável de atividades com o aparelho em mãos. Muitas dessas atividades promovem o encontro do virtual com o real, em tempos variáveis, espaços distintos, multimodais e multimídias.

Pierre Lévy (2000) e Manuel Castells (1999) publicaram duas obras icônicas no apagar das luzes do século XX: Cibercultura e Sociedade em Rede, respectivamente. Obras que ecoam até os dias atuais por suas impressionantes previsões de um futuro sociotécnico - mesmo em um tempo de internet incipiente, de domínio dos produtos Microsoft e do personal computer (PC) ocupando substancial espaço nas mesas e nos escritórios pelo mundo. É possível afirmar que Lévy e Castells anteviram muito do que vivemos hoje - 20 depois do lançamento das primeiras edições de suas obras.

Diversas inovações com possibilidades de aplicação na Educação vêm sendo criadas desde então. Uma delas é a modalidade de educação híbrida. Castro e Damiani (2011) sublinham que ainda se discute pouco sobre projetos que inter-relacionam atividades pedagógicas presenciais físicas e presenciais virtuais. Segundo Palloff e Pratt (1999, p. 130), "um curso ministrado tanto presencialmente quanto online pode dar aos educandos a oportunidade de alternarem o modo como aprendem, dependendo da necessidade e da capacidade de trabalhar neste ou naquele sistema”. $\mathrm{Na}$ medida em que um ambiente pedagógico tenha como meta criar situações de aprendizagem significativas e mediante um projeto de ensino com disponibilidade subjetiva e objetiva para estabelecer diálogo permanente, tal ambiente pode até ultrapassar as condições atuais do regime presencial físico tradicional. 
Santana et al. (2006), Castro e Damiani (2011) buscaram avaliar experiências educacionais híbridas em disciplinas de graduação e pós-graduação, respectivamente. Suas pesquisas evidenciaram manifestações positivas dos estudantes em relação à utilização de um Ambiente Virtual de Aprendizagem (AVA), concomitantemente às atividades do presencial-físico. Os sujeitos de ambas as pesquisas foram unânimes ao destacarem o melhor aproveitamento nas disciplinas desenvolvidas no formato híbrido no concernente a suas aprendizagens.

A perspectiva de aprendizado com tecnologias móveis parte de premissa convergente à educação híbrida, em termos de flexibilização das atenuantes espaço e tempo. Mas vai além, pois é uma aprendizagem híbrida - ou totalmente online - e móvel.

Lucena (2016) salienta que a primeira década do século XXI é marcada por outra transformação tecnológica, esta causada pela frequente utilização das tecnologias móveis conectadas em redes. Os tablets, notebooks, smartphones e outros dispositivos móveis têm possibilitado uma comunicação desprendida de lugares fixos e que utiliza diferentes linguagens e novos processos sociotécnicos - próprios desse novo ambiente informacional e da cultura da mobilidade. Para esta autora, a comunicação móvel materializa o sentido da expressão tudo ao mesmo tempo agora o tempo todo.

$\mathrm{Na}$ concepção de Lucena (2016), atualmente, além da cultura digital e da Cibercultura, vivenciamos a cultura da mobilidade, que se desenvolveu com o constante uso das tecnologias móveis conectadas em redes do tipo Wi-fi, WiMax e peer-to-peer. Tecnologias e demais dispositivos que cabem na palma da mão e podem ser carregados para qualquer lugar, criando redes móveis de pessoas e tecnologias nômades localizadas em diferentes espaços geográficos do planeta.

De acordo com estudos de Souabni et al. (2016), o aprendizado ubíquo é considerado uma evolução do conceito de aprendizado móvel (m-learning). Esses autores explicam que a aprendizagem ubíqua (u-learning) se refere aos processos mediados por uma infraestrutura computacional que permite aos usuários o aprendizado em seus próprios contextos ou situações, através de informações online ou físicas que facilitam e guiam o aprendizado. 
O constante e veloz aumento do uso de dispositivos móveis e a intensidade de sua influência no cotidiano das pessoas, associados à velocidade da evolução das tecnologias - melhorias nos sistemas de comunicação e acesso intuitivo às informações -, possibilitam que o processo de aprendizagem seja cada vez mais mediado por esses dispositivos. $\mathrm{O}$ aprendizado passa a ocorrer a qualquer momento e em qualquer lugar, de forma ubíqua, autônoma e criativa.

Segundo Souabni et al. (201), em um ambiente ubíquo, o contexto dos usuários é constantemente monitorado, sendo utilizado pelo sistema para adaptar as atividades propostas de modo a personalizar as atividades de ensino e intensificar as experiências de aprendizagem. Ambientes de u-learning também possuem a capacidade de utilizar não somente informações online, mas também objetos físicos, provendo um aprendizado verdadeiramente ubíquo aos aprendentes.

Lucena (2016) e Certeau (2011) enfatizam que, para conceber esta escola - hoje permeada pelas tecnologias e por jovens que, fora dela, vivenciam outras formas de produzir e consumir conteúdos, sendo considerados praticantes culturais, atuantes nas mídias e redes sociais - é necessário o desenvolvimento de pesquisas que possibilitem a compreensão da sociedade contemporânea, dos sujeitos que nela atuam e dos espaços formais e não formais de educação.

Após essa síntese a respeito de três perspectivas educacionais contemporâneas, dentro do escopo das tecnologias emergentes, na sequência, serão apresentados e discutidos os dados oriundos da investigação sobre a presença de disciplinas voltadas ao ensino com e pelas tecnologias nos currículos dos cursos de Pedagogia das IES das sete capitais da Região Norte do país.

\section{As tecnologias emergentes no currículo dos cursos de Pedagogia}

A organização básica dos cursos de Pedagogia (no momento da publicação deste artigo) é regida pela resolução CNE/CP No 1 , de 15 de Maio de 2006, que institui Diretrizes Curriculares Nacionais para o Curso de Graduação em Pedagogia, licenciatura (Brasil, 2006). 
Palavras derivadas de "tecnologia" são mencionadas duas vezes ao longo das seis páginas do documento. No Art. 40: "III - produção e difusão do conhecimento científico-tecnológico do campo educacional, em contextos escolares e não-escolares" (Brasil, 2006, p. 2). E no Art. 5: "relacionar as linguagens dos meios de comunicação à educação, nos processos didático-pedagógicos, demonstrando domínio das tecnologias de informação e comunicação adequadas ao desenvolvimento de aprendizagens significativas" (Brasil, 2006, p. 2).

Mesmo não constando a palavra flexibilidade (ou seus derivados) no referido documento, para além das bases obrigatórias para sua implantação (BRASIL, 2006), as instituições autorizadas e reconhecidas pelo Ministério da Educação (MEC) a ofertarem um curso de Pedagogia gozam de considerável autonomia (essa palavra consta duas vezes no documento) para a construção e efetivação de seu currículo - em evidência no Art. $6^{\circ}$ e com destaque para a seguinte orientação:

I - um núcleo de estudos básicos que, sem perder de vista a diversidade e a multiculturalidade da sociedade brasileira, por meio do estudo acurado da literatura pertinente e de realidades educacionais, assim como por meio de reflexão e ações críticas, articulará:

a) aplicação de princípios, concepções e critérios oriundos de diferentes áreas do conhecimento, com pertinência ao campo da Pedagogia, que contribuam para o desenvolvimento das pessoas, das organizações e da sociedade (Brasil, 2006, p. 3).

Desde o ponto de vista da orientação transcrita e da relativa autonomia para a constituição de um curso de Pedagogia, neste estudo, foi investigada a carga horária dedicada a disciplinas direcionadas ao ensino do trabalho pedagógico com as tecnologias emergentes ${ }^{3}$.

Tratou-se de uma pesquisa de abordagem qualitativa, do tipo observacional (Bauer; Gaskell, 2002), na qual se utilizou a análise documental para a coleta de dados, também abordada por esses autores, e a análise

\footnotetext{
${ }^{3} \mathrm{Ou}$ mesmo disciplinas que se aproximem e/ou enfoquem da/a relação pedagógica entre tecnologia e Educação, com outras denominaçõ̂es.
} 
textual discursiva (Moraes, 2003) para a análise de dados. Os documentos analisados foram os currículos dos cursos de Pedagogia das universidades federais das sete capitais dos estados da Região Norte do Brasil: Universidade Federal do Acre (UFAC), Universidade Federal do Amazonas (UFAM), Universidade Federal do Pará (UFPA), Universidade Federal de Roraima (UFRR), Universidade Federal do Tocantins (UFT), Universidade Federal do Amapá (UNIFAP) e Universidade Federal de Rondônia (UNIR). A busca pelas grades curriculares atualizadas foi realizada nos sítios institucionais dessas universidades.

O Quadro 1 apresenta os dados gerais:

Quadro 1 - Currículos de Pedagogia das IES sediadas em todas as capitais da Região Norte

\begin{tabular}{|c|c|c|c|c|}
\hline Universidade & Ano & C. horária total & $\begin{array}{c}\text { Disciplinas } \\
\text { tecnologia }\end{array}$ & $\begin{array}{c}\text { C. horária } \\
\text { tecnologias }\end{array}$ \\
\hline UFAC & 2009 & 3525 horas & $1^{*}$ & $60 \mathrm{~h}^{*}$ \\
\hline UFAM & 2008 & 3325 horas & $1^{*}$ & $60 \mathrm{~h}^{*}$ \\
\hline UFPA & 2012 & 3220 horas & 2 & $105 \mathrm{~h}$ \\
\hline UFRR & 2009 & 3228 horas & 1 & $60 \mathrm{~h}$ \\
\hline UFT & 2008 & 3225 horas & 1 & $60 \mathrm{~h}$ \\
\hline UNIFAP & 2009 & 3565 horas & 1 & $60 \mathrm{~h}$ \\
\hline UNIR & 2013 & 3480 horas & 3 & $220 \mathrm{~h}$ \\
\hline
\end{tabular}

Fonte: Sítio dos cursos de Pedagogia ou dos departamentos responsáveis por esse curso em cada IES

* Disciplinas optativas/eletivas, não obrigatórias

Como esperado, todos os cursos de Pedagogia cumprem com a legislação atual vigente (Brasil, 2006) em suas orientações basilares. Do ponto de vista da autonomia antes referida, constata-se a pluralidade entre as sete grades curriculares, o que é bastante salutar. Especificidades locais são incorporadas em todos eles e disciplinas direcionadas ao trabalho pedagógico de múltiplas linguagens estão presentes. Verifica-se um esforço legítimo dos cursos de Pedagogia em contemplar temáticas emergentes desde diferentes pontos de vista, fundamentalmente aquelas de maior apelo social, cultural e vinculadas a políticas de inclusão. Mesmo nos casos de grades curriculares baseadas em Projetos Pedagógicos mais 
antigos (onze anos), como os de 2008, da UFAM e da UFT, e os de 2009 (dez anos), da UFAC, da UFRR e da UNIFAP - conforme mostra o Quadro 1.

O Quadro 1 também apresenta a carga horária total dos currículos dos cursos de Pedagogia das sete IES e as disciplinas direcionadas à relação Educação e tecnologias e a carga horária total a disciplinas voltadas para essa temática.

Não avalio como coincidência o currículo mais recente, da UNIR, ser o que maior carga horária dedica a disciplinas direcionadas à relação Educação e tecnologias: 220 horas obrigatórias, entre três disciplinas. O curso de Pedagogia da UFPA, de 2012, oferta duas disciplinas obrigatórias dentro da temática, totalizando carga horária de 105 horas. Respectivamente, 6.32\% da carga horária no curso de Pedagogia da UNIR e 3,26\% na Pedagogia da UFPA. UFRR, UFT e UNIFAP ofertam uma disciplina direcionada à temática supracitada, que representam, respectivamente, $1.85 \%, 1,86 \%$ e $1,68 \%$ da carga horária total de seus cursos. A situação das grades curriculares dos cursos de Pedagogia da UFAC e da UFAM é diferente, pois ofertam somente uma disciplina nessa temática, mas como optativa/eletiva. A situação é diferente, tendo em vista que, se o acadêmico não optar por essa disciplina, cumprirá a carga horária total do curso sem assistir a uma disciplina sequer que trabalhe pedagogicamente esse conteúdo (0\%) ao longo de todo o curso de Pedagogia.

$\mathrm{O}$ achado em destaque vai ao encontro da pesquisa desenvolvida por Souza (2013), em algumas IES, que constatou haver nas grades curriculares dos cursos de licenciatura apenas uma disciplina relacionada ao uso das tecnologias na Educação. Ainda, em diversos casos, essa disciplina não possuía carga horária obrigatória, tratando-se de disciplina optativa ou complementar.

O Quadro 2 apresenta os nomes das disciplinas e suas cargas horárias. As nomenclaturas são bastante similares e abrangentes do ponto de vista conceitual. 
Quadro 2 - Disciplinas relacionadas à Educação e Tecnologia ofertadas pelas IES

\begin{tabular}{|l|l|l|}
\hline Universidade & Disciplinas & $\begin{array}{l}\text { C. horária por } \\
\text { disciplina }\end{array}$ \\
\hline UFAC & Educação a Distância & $60 \mathrm{~h}^{*}$ \\
\hline UFAM & Informática Aplicada à Educação & $60 \mathrm{~h}^{*}$ \\
\hline \multirow{2}{*}{ UFPA } & Tecnologias e Mídias na Educação & $60 \mathrm{~h}$ \\
\cline { 2 - 3 } & Educação Profissional e Tecnológica & $45 \mathrm{~h}$ \\
\hline \multirow{2}{*}{ UFRR } & $\begin{array}{l}\text { Tecnologia da Informação e } \\
\text { Comunicação aplicada à Educação }\end{array}$ & $60 \mathrm{~h}$ \\
\hline UFT & Educação e Tecnologias & $60 \mathrm{~h}$ \\
\hline UNIFAP & Educação e Tecnologia & $60 \mathrm{~h}$ \\
\hline \multirow{4}{*}{ UNIR } & Tecnologia Aplicada à Educação & $80 \mathrm{~h}$ \\
\cline { 2 - 3 } & Educação Profissional Tecnológica & $60 \mathrm{~h}$ \\
\cline { 2 - 3 } & $\begin{array}{l}\text { Fundamentos e Prática da Educação a } \\
\text { Distância }\end{array}$ & $80 \mathrm{~h}$ \\
\hline
\end{tabular}

Fonte: Sítio dos cursos de Pedagogia ou dos departamentos responsáveis por esse curso em cada IES

* Disciplinas optativas/eletivas, não obrigatórias

É interessante destacar a situação da disciplina sobre Educação a Distância (EaD). Apenas dois cursos de Pedagogia a ofertam: UFAC e UNIR. Segundo dados recentes do Instituto Nacional de Estudos e Pesquisas Educacionais Anísio Teixeira (INEP, 2017), os cursos a distância já representam mais da metade de matrículas e graduados no Ensino Superior brasileiro. Além disso, os ambientes virtuais de aprendizagem (AVA) estão presentes em todas as IES federais do país ${ }^{4}$, e duas grandes redes de EaD estão presentes e atuantes no país há mais de dez anos: UAB (Universidade Aberta do Brasil) e UNA-SUS (Universidade Aberta do Sistema Único de Saúde). Penso que uma modalidade com tamanha incidência sobre a população - principal "responsável" pela democratização do acesso ao Ensino Superior nos interiores do país e portadora de possibilidades de inovações comunicacionais e pedagógicas-, não deveria estar de fora da grade curricular de um curso de Pedagogia.

${ }^{4} \mathrm{O}$ Moodle (Modular Object-Oriented Dynamic Learning Environment) é o mais utilizado. Maiores detalhes em moodle.org. 
Cabe questionar, ainda, sobre a presença da "cultura tecnológica" (Litwin, 1998) nos cursos de formação inicial de professores. Havendo ou não disciplinas direcionadas à relação Educação e tecnologia, uma cultura de uso e conhecimento para a prática docente pode estar sendo desenvolvida ao longo dos cursos de Pedagogia. Litwin (1998) já nos ensinava que não basta o professor ser tecnicamente treinado para o uso das tecnologias se ele próprio não viver e apreender a cultura pedagógica envolvida nos processos de ensino e de aprendizagem. É o que se fala bastante no senso comum sobre os nativos digitais: são pessoas que já nasceram em uma cultura digital móvel conectada. A cultura já está no DNA. Contudo, o que se observa em escolas (e também em universidades) é uma série de dificuldades que levam a uma situação de visível falta de sintonia entre a cultura vivenciada na educação formal com a cultura dos aprendentes do lado de fora dos muros dos educandários.

A análise até aqui empreendida releva elementos iniciais para dialogar sobre a presença e a incidência de disciplinas voltadas à relação Educação e tecnologia nos currículos de cursos de Pedagogia. Por si só, a oferta dessas disciplinas não garante uma formação plena de professores que utilizarão as tecnologias emergentes como ferramentas didáticas de mediação (Vygotski, 1931/1995; Daniels, 2003; Prestes, 2010; Castro, 2014) em suas práticas pedagógicas, de forma sintonizada com o cotidiano de seus aprendentes (Freire, 2011). Entretanto, a constituição das grades observadas desvela sinais e revela prioridades curriculares - e essa temática específica não está entre as prioridades. Nesse contexto, cabe outra questão: nós, professores-pesquisadores do Ensino Superior, que realizamos pesquisas nas escolas e vimos constatando dificuldades no empreendimento de didáticas inovadoras dos professores com as tecnologias emergentes, estamos preparando efetivamente esses professores para dar conta dessa prática exitosa que tanto almejamos? 


\section{Problematizações e questionamentos parciais}

Há considerável produção acadêmico-científica sobre as possibilidades de uso das tecnologias emergentes nos mais diversos níveis educacionais e para o ensino em variadas áreas do conhecimento. Todavia, o cotidiano da escola pública brasileira revela demora na incorporação das tecnologias emergentes como ferramentas didáticas efetivas de mediações de aprendizagens.

Para além da falta de estrutura e das próprias ferramentas nas escolas, é necessário refletir sobre a formação inicial de professores. Pois professores formados para o uso didático de smartphones em sala de aula, por exemplo, podem promover atividades educativas de qualquer conteúdo, sem grandes investimentos em infraestrutura, sem um laboratório de informática. Uma atividade com os dispositivos móveis dos jovens, utilizando a internet, pode contemplar os conceitos de educação híbrida, aprendizado ubíquo e, obviamente, o uso das tecnologias móveis, simultaneamente. Mas e se a escola não dispõe de internet? Em outro local, o professor e seus aprendentes podem fazer o download dos aplicativos (app) e realizar todas as atividades off-line (sem a necessidade do acesso à internet em tempo real) na escola.

A realidade está posta: professores e estudantes usam as tecnologias móveis intensamente no cotidiano social; escolas e universidades ainda não sabem como lidar com essa cultura intramuros. A morosidade é tão evidente na incorporação do uso pedagógico das tecnologias emergentes nas escolas públicas que muitas escolas nem chegarão a ter laboratórios de informática. Vão pular essa parte. Vão passar da televisão diretamente para as tecnologias móveis.

Diante desse cenário antagônico, é imperioso indagar: qual deve ser a carga horária de disciplinas voltadas ao uso educacional das tecnologias emergentes nos cursos de Pedagogia? Com que intensidade o uso dessas tecnologias deve ser trabalhado pelos acadêmicos de Pedagogia ao longo do curso? A "cultura tecnológica", cada vez mais híbrida, móvel e ubíqua, está incorporada no percurso da formação inicial de professores? 


\section{Referências}

BAUER, Martin; W. GASKELL, George. Pesquisa Qualitativa com Texto, Imagem e Som: um manual prático. Petrópolis: Vozes, 2002.

BRASIL. Resolução CNE/CP No 1, de 15 de maio de 2006. Institui Diretrizes Curriculares Nacionais para o Curso de Graduação em Pedagogia, licenciatura. 2006.

CASTELLS, Manuel. A sociedade em rede. 10. ed. São Paulo: Paz e Terra, 1999.

CASTRO, Rafael F. de. A expressão escrita de acadêmicas de um curso de pedagogia a distância: uma intervenção Histórico-Cultural. 2014. 238f. Tese (Doutorado) - Programa de Pós-Graduação em Educação. Universidade Federal de Pelotas, Pelotas, 2014.

CASTRO, Rafael F. de.; DAMIANI, Magda F. Uma experiência de educação híbrida: estudo de caso em um curso de pós-graduação. CINTED-UFRGS Novas Tecnologias na Educação, Porto Alegre, v. 9, n. 2, dez., 2011.

CERTEAU, M. de. A invenção do cotidiano: artes de fazer. Petrópolis: Editora Vozes, 2011.

DANIELS, Harry. Vygotsky e a Pedagogia. São Paulo: Edições Loyola, 2003.

FREIRE, Paulo. Pedagogia da Autonomia - Saberes necessários à prática educativa. 43. ed. Rio de Janeiro: Editora Paz e Terra, 2011.

FREITAS, M. T. A. O pensamento de Vygotsky nas reuniões da ANPEd (1998-2003). Educação e Pesquisa, São Paulo, v. 30, n. 1, p. 109-138, 2004.

INEP. Instituto Nacional de Estudos e Pesquisas Educacionais Anísio Teixeira / Censo da Educação Superior. Disponível em: <http://inep.gov.br/web/guest/educacao-superior > Acesso em: 5 de outubro de 2018.

LÉVY, Pierre. Cibercultura. São Paulo: Editora 34, 2000.

LITWIN, Edith. Tecnologia educacional: Política, História e Proposta. Porto Alegre: Artmed, 1998.

LUCENA, Simone. Culturas digitais e tecnologias móveis na educação. Educar em Revista, Curitiba, n. 59, p. 277-290, jan./mar. 2016.

MORAES, Roque. Uma tempestade de luz: a compreensão possibilitada pela análise textual discursiva. Ciência e educação. Bauru, v. 9, n. 2, p.191-211, 2003.

PALLOFF, M.; PRATT K. Construindo comunidades de aprendizagem no ciberespaço. Porto Alegre: Artmed, 2002. 
PRESTES, Zoia R. Quando não é quase a mesma coisa: Análise de traduções de Lev Semionovitch Vigotski no Brasil. Repercussões no campo educacional. 2010. 295f. Tese (Doutorado em Educação) - Programa de Pós-Graduação em Educação, Universidade de Brasília, Brasília, 2010.

SANTANA, Otacílio; IMAÑA ENCINAS, José; COUTO JÚNIOR, Antônio F. Ensino presencial e virtual na disciplina de Metodologia de Pesquisa Florestal. Anais do... Cobenge - Ensino de Engenharia: empreender e preservar, 34, Passo Fundo, 2006.

SELAU, Bento; CASTRO, Rafael F. de. Cultural-historical approach: educational research in different contexts. Porto Alegre: EDIPUCRS, 2015.

SOUABNI, R.; SAADI, I. B.; SALAH, N. B.; GHEZALA, H. B. On the evaluation of quality of situation (qosi) in situation-aware ubiquitous learning environment. Anais do... Advanced Information Networking and Applications (AINA) / IEEE 30th International Conference on. IEEE, p. 239-246, 2016.

SOUZA, A. de G. Entre a prática e a teoria: a inserção das tecnologias da informação e comunicação (TIC) na formação inicial da Universidade Estadual de Feira de Santana. Dissertação (Mestrado em Educação) - Universidade Tiradentes, Aracaju, 2013.

VYGOTSKI, L. S.. Obras Escogidas. Tomo III (Historia del Desarrollo de las Funciones Psíquicas Superiores). Madri: Visor, 1931/1995.

VYGOTSKY, L. S. Obras Escogidas. Tomo II (Pensamiento Y Lenguaje). Moscú: Editorial Pedagógica, 1934/1982. 


\section{A FORMACCÃO DE PROFESSORES DA EDUCAÇÃO PROFISSIÓNAL: DESAFIOS E POSSIBILIDADE'S}

Jacqueline Oliveira Lima Zago

\section{Introdução}

Este artigo tem como objetivo registrar uma experiência de Formação Pedagógica em serviço com professores inseridos no Programa Nacional de Acesso ao Ensino Técnico e Emprego (Pronatec), criado pelo Governo Federal em 2011 e implementado pelo Centro de Educação Profissional (Cefores), instituição vinculada à Universidade Federal do Triângulo Mineiro (UFTM).

No ápice de execução do programa em 2014, com 122 professores-bolsistas vinculados para oferta de 21 cursos de nível técnico (Concomitante e subsequente ao Ensino Médio) e 80 cursos de Formação Inicial e Continuada (FIC), a experiência de oferecer um curso de Formação Pedagógica veio como resposta à necessidade de preparar profissionais das diferentes áreas de atuação técnica para a sala de aula.

Após um ano de execução do Programa pelo Cefores-UFTM, a direção executiva juntamente com a equipe pedagógica multidisciplinar ${ }^{1}$ criada no âmbito local, perceberam que muitos profissionais contratados como bolsistas para atuarem como docentes nos cursos não tinham formação como professores. Embora tivessem passado por um processo seletivo público, esses profissionais foram selecionados pela experiência exitosa nas suas respectivas áreas de atuação. A demanda identificada e confirmada

\footnotetext{
${ }^{1}$ A Equipe de Coordenação e Pedagógica do Pronatec-Cefores-UFTM, neste período, foi composta pelos seguintes profissionais: José Eduardo dos Reis Félix (Coordenador Geral), Jacqueline Oliveira Lima Zago (Pedagoga), Teresinha das Graças Lima (Coordenadora Pedagógica), Paulina Abdalla Palis (Fonoaudióloga), Sheila Silva Parreira (Psicóloga), Luciene Maria de Souza (Técnica em Assuntos Educacionais), Lívia Cristina Lima Diniz (Terapeuta Educacional), Sonia Felix (Pedagoga).
} 
pelos próprios professores passou a ser uma intervenção da equipe pedagógica e multidisciplinar para refletir sobre a ação educativa de maneira mais ampla na criação de uma proposta de Formação Pedagógica no âmbito do Pronatec - Cefores - UFTM, pois, além de esses profissionais requererem essa formação, os espaços de atuação deles eram os mais diversos, incluindo casas de apoio, unidades prisionais, instituição para jovens privados de liberdade em cumprimento de medidas socioeducativas, entre outros.

\section{O contexto de criação do Pronatec}

Após um período de significativa expansão de oferta de vagas na Educação Superior de maneira geral e especialmente na UFTM, o governo do Partido dos Trabalhadores - PT organizou a agenda de políticas para a Educação Profissional, lançando o Pronatec. Criado para atender a demanda registrada pelos municípios, especialmente nas diferenças entre vagas oferecidas e não contempladas para emprego, a Lei 12.513 de 26/10/2011, bem como as resoluções subsequentes aprovadas pela Secretaria de Educação Profissional e Tecnológica (Setec), lançou cursos gratuitos, ancorados na assistência estudantil que tinha como foco garantir aos alunos a permanência no curso, tais como: alimentação, transporte e materiais escolares.

O projeto foi encaminhado para tramitação no Congresso Nacional, em abril de 2011, onde ganhou adesão dos parlamentares, sofrendo poucas emendas e aprovado em outubro do mesmo ano. Foi constituído por subprogramas, projetos e ações de assistência técnica e financeira, que convergem a fim de ampliar o acesso à educação profissional. Importante ressaltar que boa parte das ações já eram executadas pela Secretaria de Educação Profissional e Tecnológica - Setec/MEC. O Pronatec, assim, veio para congregar essas ações.

A Setec/MEC responde pela coordenação do Sistema Nacional de Educação Profissional e Tecnológica, integrado pela Rede Federal de Educação Profissional e Tecnológica - Institutos Federais de Educação Técnica e Tecnológica - IFETs; Universidade Federal Tecnológica do Paraná UFTPR; Centro Federal de Educação Tecnológica - CEFETs de Minas 
Gerais e do Rio de Janeiro; redes estaduais de Ensino Profissional e Técnico - EPT; o Sistema S (Senai, Sesi, Senat, Sesc) e as instituições privadas credenciadas para operar com o Fundo de Financiamento Estudantil - Fies.

Para atender os seus principais objetivos, o Pronatec elegeu um grupo prioritário de suas ações, a saber: I - estudantes do ensino médio da rede pública, inclusive da educação de jovens e adultos; II - trabalhadores, inclusive agricultores familiares, silvicultores, aquicultores, extrativistas e pescadores; III - beneficiários titulares e dependentes dos programas federais de transferência de renda, entre outros que atenderem a critérios especificados no âmbito do Plano Brasil sem Miséria; IV - pessoas com deficiência; V - povos indígenas, comunidades quilombolas e outras comunidades tradicionais; VI - adolescentes e jovens em cumprimento de medidas socioeducativas; VII - públicos prioritários dos programas do governo federal que se associem à Bolsa-Formação; e VIII - estudantes que tenham cursado o ensino médio completo em escola da rede pública ou em instituições privadas na condição de bolsista integral.

O ressurgimento da Educação Profissional como elemento estratégico do desenvolvimento do país, teoria publicizada no governo do PT, foi uma tentativa de resposta às necessidades qualitativas e quantitativas do mercado. O Pronatec, que materializou o ressurgimento da educação profissional como política central do governo petista e como forma de acesso ao trabalho e emprego, torna-se assim a materialização dessa contradição quando, de um lado,

[...] contraria a concepção de integração reconstruída nos últimos anos, de outro atende a concepção oficial expressa na atualização das Diretrizes Curriculares Nacionais para a Educação Profissional, mediante as 'articulações' que reforçam as parcerias com o setor privado, estratégicas para a desobrigação do Estado em relação a esta modalidade de ensino e oportuna para os interesses do setor privado (...) O Estado assume o papel de indutor das políticas educacionais e responsabiliza-se pela sua oferta pública. O paradoxo que se instala, em termos legais, é que ao mesmo tempo em que ocorre um avanço provocado pela concepção vigente para o Ensino Médio, convive-se com uma proposta oficial para 
a Educação Profissional Técnica de Nível Médio retrógada, balizada exclusivamente pelo mercado, como se a educação fosse um problema econômico (Saldanha, 2012, p. 8-9).

Como justificativas para as suas opções políticas e também pedagógicas, o Pronatec se utiliza de análises que apontam o baixo nível de escolaridade da força de trabalho brasileira, comparada com o desenvolvimento tecnológico e de produção do país. Segundo dados do Instituto de Pesquisa Econômica Aplicada - IPEA (2014), 53\% da população ativa com mais de 15 anos não concluíram sequer o Ensino Médio.

Assim, com o mercado demandando protagonismo do Estado na organização da educação profissional e técnica no Brasil, e com o governo ciente do contexto oportuno e da necessidade de se criar ambiente competitivo à produção de bens e serviços no país, a organização do Pronatec veio como resposta a essa demanda (IPEA, 2014, p. 11-12).

O mesmo relatório, quando analisa os arranjos político-institucionais do Pronatec, descreve que:

O programa é parte de uma estratégia de desenvolvimento, em escala nacional, que busca integrar a qualificação profissional de trabalhadores com a elevação da sua escolaridade, constituindo-se em um instrumento de fomento ao desenvolvimento profissional, de inclusão social e produtiva e de promoção da cidadania (IPEA, 2014, p. 34).

O relatório defende que, com a retomada do crescimento econômico a partir de 2004, a falta de qualificação da força de trabalho colocava o país em situação muito frágil.

[...] o Pronatec é um programa bastante abrangente, resultado da decisão de se enfrentar um problema atual em fase aguda: a baixa escolaridade e qualificação de parcela majoritária dos trabalhadores brasileiros, em um momento em que o crescimento da economia exigia crescentes volumes de mão de obra especializada. Ele busca atacar 
todas as principais causas do problema e atender, mediante ações flexíveis, a características específicas dos diversos segmentos da população trabalhadora, tal como percebido ou demandado em cada caso. O seu desenho revela, portanto, compreensão da situação do trabalhador brasileiro, da trajetória da economia nacional e do estágio em que se encontra a EPT no país (IPEA, 2014, p. 48).

No esboço do programa está expresso o compromisso de atender prioritariamente estudantes do ensino médio da rede pública, EJA, trabalhadores, beneficiários dos programas sociais, com vistas a dar ênfase aos portadores de deficiência e aos programas realizados nas regiões norte e nordeste. O programa também é vinculado a outros programas não somente com ações do Ministério da Educação, mas também da Secretaria de Justiça, Ministério de Relações Humanas, Relações Exteriores, entre outros, de acordo com a demanda ou interesse identificados por esses órgãos, como, por exemplo, adolescentes institucionalizados, beneficiários da seguridade social, entre outros.

A organização para execução das vagas, via financiamento bolsa-formação, com recursos do Fundo Nacional para o Desenvolvimento da Educação - FNDE, se alicerçou basicamente em transferências de recursos para as instituições (públicas e privadas) em rubricas específicas para pagamento de profissionais docentes e técnicos, em forma de bolsas de extensão, custeio de materiais diversos de consumo, transporte e alimentação dos alunos. Os valores repassados foram vinculados ao número de alunos matriculados e frequentes, controlados pelo Sistec (Sistema de Gestão da Educação Técnica) e monitorados pela Setec.

Para compreender o processo que tomou forma e fez que o executivo federal assumisse a tarefa de responder à demanda do mundo dos negócios por trabalhadores qualificados ${ }^{2}$, será preciso um recorte histórico, tendo em

\footnotetext{
${ }^{2}$ Para Santos e Lucena, "a educação profissional é vista sob a égide da lógica da empregabilidade, que defende a lógica da razão instrumental. É exigido do trabalhador que ele se 'qualifique' não necessariamente para ser absorvido pelo mercado de trabalho, mas para estar em condição de empregabilidade, ou seja, para estar disponível no exército de reserva” (2007, p. 236) .
} 
vista que uma mudança de perspectiva não se explica por si só, mas como resposta a um movimento social ou econômico que, conforme nos esclarece os autores vinculados à corrente marxiana, se ancora na luta de classes (Antunes, 1995, 2009; Lucena, Lombardi, Previtali, 2014; 2013).

Buscando compreender os argumentos socioeconômicos, político-educacionais e ideológicos para a implantação do Pronatec, Deitos, Lara e Zanardini (2015) analisam as relações e mediações entre o Estado e a política pública de educação profissional. Para esses autores, o Pronatec se apresenta como programa integrador da política educacional para a educação profissional no país, assumindo, no tocante à formação da força de trabalho, uma estratégia para viabilizar as políticas macroeconômicas adotadas. Daí que a qualificação se torna preponderante em relação à formação humana.

Ainda assim, entendemos neste trabalho que, mesmo diante das contradições entre as instâncias de fomento, os limites materiais e concretos, o Pronatec poderia ser um instrumento de resistência da classe trabalhadora para a sua própria sobrevivência. Nesse entendimento, o Cefores-UFTM aceitou coordenar de cursos demandados via Sistec, formando para isso uma equipe multidisciplinar de Supervisores de Cursos e Equipe Pedagógica e Multidisciplinar.

Os primeiros estudos acadêmicos sobre o Pronatec identificaram que a evasão dos alunos nos cursos oferecidos é um dos problemas enfrentados pelas unidades ofertantes. Os autores ${ }^{3}$ que vêm estudando a temática apontam vários fatores que contribuem para esse desfecho, mas, em virtude do recorte deste trabalho, não serão aprofundados. $O$ fato é que mesmo conscientes das contradições inerentes da relação do mundo dos negócios com a classe trabalhadora, mediada pelo Estado, o Pronatec-Cefores-UFTM procurou construir estratégias para minimizar os problemas encontrados.

Nem sempre a demanda registrada corresponde ao interesse da população, assim, muitos cursos são liberados para as instituições executantes, mas, como não são feitas inscrições em número suficiente, as turmas

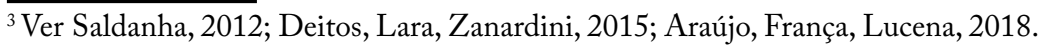


são canceladas. A gestão central do Pronatec libera os cursos/vagas para as diferentes instituições ligadas ao governo federal, ao governo estadual, ao Sistema $\mathrm{S}$ e mesmo a instituições privadas. Isso faz que as instituições concorram entre si pelos alunos.

\section{O Centro de Educação Profissional /UFTM e o Pronatec}

O Centro de Educação Profissional - Cefores é uma Instituição Federal, Pública, escola vinculada à Universidade Federal do Triângulo Mineiro - UFTM e subordinada à SETEC - Secretaria de Educação Profissional e Tecnológica/MEC. Foi criada em 1990 para atender à demanda local de trabalhadores, especialmente, para atender o Hospital Escola, com os cursos técnicos em Enfermagem, Farmácia, Radiologia e Patologia.

Ao longo dos anos de atuação, o Cefores ampliou a sua área de atuação, passando a oferecer outros cursos: Segurança do Trabalho, Saúde Bucal e o curso de Informática, todos de nível técnico. O Pronatec, para o Cefores, foi entendido, pela gestão, como oportunidade de ampliar o que já estava sendo realizado, com considerável aprovação da sociedade local, o que foi feito a partir de 2012, nos moldes do programa.

Uma das primeiras opções da execução local foi a criação de uma Equipe de Supervisores de Cursos, Administrativo e Financeiro e Psicopedagógico. Esta última equipe congregou profissionais multidisciplinares para assessorar a Coordenação Geral, Adjunta e Pedagógica nos assuntos psicopedagógicos. Os profissionais envolvidos foram Fonoaudiólogos, Psicólogos, Pedagogos e Terapeutas Ocupacionais, que tinham como foco:

a) orientar e acompanhar as atividades e a frequência dos estudantes, realizando diagnóstico quando os estudantes estão em processo de evasão e criando alternativas para a manutenção do aluno;

b) acompanhar os estudantes em potencial e orientá-los no processo de escolha do curso;

c) promover atividades de sensibilização e integração entre os estudantes e equipes do Pronatec; 
d) articular ações de inclusão produtiva em parceria com os SINES (Pronatec Cefores-UFTM, 2011).

As principais atividades dos profissionais envolvidos podem ser objetivamente descritas como:

a) Criar mecanismos de acompanhamento e de assistência que permitam o acesso, a permanência e a conclusão de cursos técnicos aos beneficiários das atividades Pronatec;

b) Identificar a necessidade de apoio psicopedagógico e realizar o encaminhamento para o serviço especializado (Pronatec Cefores-UFTM, 2011).

A opção executiva do Coordenador do Programa no âmbito do Cefores - UFTM de constituir uma equipe multidisciplinar é considerada, neste artigo, como inovação no processo de execução local do Pronatec.

A primeira necessidade identificada por essa equipe multidisciplinar foi a elaboração dos Projetos Pedagógicos dos diferentes cursos. Muitos cursos pactuados não eram cursos regulares do Cefores e, para a sua construção, seria necessária a participação dos professores que atuariam no curso. A primeira ação, então, foi proporcionar uma oficina de elaboração de Projetos Pedagógicos para os Professores Supervisores de Cursos em conjunto com os professores bolsistas. Esse foi o primeiro desafio, tendo em vista a própria formação das equipes de professores, que eram contratados apenas quando já havia matrículas confirmadas. Ou seja, o primeiro planejamento era feito pelos professores efetivos do Cefores, os quais, muitas vezes, não eram da área do curso, e o Projeto do Curso só seria validado quando os professores que o executariam fossem contratados. Assim, o prazo de análise das propostas era praticamente inexistente, ou seja, a análise seria feita no decorrer do curso.

Cada projeto pedagógico, após a elaboração, foi analisado pela Equipe Pedagógica e encaminhado para o Colegiado do Cefores para aprovação. Depois disso, o documento seria encaminhado ao Conselho de Ensino e, em caso de aprovação nas instâncias, homologado pelo Conselho Superior da UFTM. O resultado desse processo foi o compromisso firmado não só pela equipe de elaboração da proposta, mas também pela instituição, via 
Conselhos. Destacamos apenas um trecho de um desses PPC que resume, pelo menos em tese, o que se pretendia com o Pronatec-Cefores-UFTM:

O desafio nosso é saber que somos responsáveis pelo resultado do curso, no reconhecimento da importância do trabalho em grupo que oportuniza a troca de saberes, valoriza as diferenças, promove a interação e exercita a responsabilidade de todos no resultado da educação. Caminhar nessa perspectiva é desenvolver na escola um local propício ao diálogo e à experimentação, incentivando a reflexão contínua da prática profissional. Portanto, queremos formar um homem capaz de atuar de maneira crítica, consciente, reflexiva e transformadora na sociedade, construindo a sua cidadania. Acreditamos que construindo um ser humano autônomo certamente construiremos uma sociedade justa, igualitária e feliz, onde todos possam viver com dignidade (Cefores, 2011, P. 44).

Foi esse movimento de construção dos PPC que deu os primeiros sinais da necessidade de Formação Pedagógica para os profissionais bolsistas em atuação, como supervisores de cursos e docentes. Muitos profissionais bolsistas contratados como professores tinham o conhecimento nas suas respectivas áreas (Cabelereiro, Maquiagem, Jardinagem etc), alguns com experiência comprovada em escolas técnicas particulares ou vinculadas ao Sistema S, mas com muito pouco conhecimento do processo de planejamento pedagógico. Durante as oficinas e reuniões, os próprios profissionais relataram que, nas escolas em que trabalharam antes, recebiam a proposta pronta, cabendo-lhes executar.

\section{O Curso de Formação Pedagógica: necessidades}

A inspiração para o Projeto de Formação Pedagógica em serviço, para os professores-bolsistas do Pronatec-Cefores-UFTM, surgiu da necessidade de compreender esse universo criado e seus desafios. As primeiras pesquisas para formatação do curso encontraram o trabalho da pedagoga Geralda Pena, do Instituto Federal de Minas Gerais de Ouro Preto, Mestre e Doutora pela UFMG, membro da Rede Latino-americana de Estudos 
sobre Trabalho Docente (Rede Estrado), com trabalhos na área de formação docente na educação profissional.

O trabalho dessa pesquisadora mostra que os professores, no processo de ensinar, adaptam, reconstroem, reordenam ou simplificam o conteúdo para torná-lo compreensível para seus alunos, mesmo que essas ações não sejam previamente analisadas sob a perspectiva pedagógica. Assim, para ela, a aprendizagem da docência não se dá de forma linear, mas em um processo construído por "um conjunto de determinações sociais que expressam os espaços que foram importantes na constituição das disposições para ensinar” (Pena, 2011, p. 101).

A autora reconhece que as escolas de educação profissional recebem profissionais, oriundos de diferentes áreas de formação, que trabalham como professores, uma vez que não há exigência de requisitos legais de formação como docente para atuar nessa modalidade de ensino. E isso se tornou mais evidente no Pronatec, quando se constatou que:

[...] a formação de professores para a EP vem sendo tratada no País, como algo especial, emergencial, sem integralidade própria, que carece de marco regulatório, e que, por meio de Programas, desenvolve-se paradoxalmente, sem a superação das situações vigentes e ditas emergenciais, e sinalizando uma política de falta de formação (Oliveira, 2010, p.458, apud Pena, 2011, p. 104).

Das análises de Pena (2011), destacamos o que delimitamos para a proposta de Formação Pedagógica para Professores Bolsistas vinculados ao Pronatec-Cefores-UFTM, como pressupostos:

- A atividade profissional é de natureza instrumental, consistindo na solução de problemas concretos por meio da aplicação de teorias e técnicas;

- Os docentes são pessoas que produzem um saber específico sobre o seu trabalho, a partir do conjunto de conhecimentos oriundos de diferentes espaços de formação e da reflexão sobre sua própria prática; 
- Não existem diretrizes sobre formação docente para atuação na Educação Profissional;

- Predomina, na Educação Profissional, a crença de que "para ser bom professor, basta o domínio da área do conhecimento específico que se vai ensinar" (Diniz-Pereira, 1999, p.112, apud Pena, 2011, p. 110).

Com esses pressupostos, foi elaborado o projeto do curso de Formação Pedagógica que priorizaria as seguintes características:

- O processo de ensino e aprendizagem tem caráter social e se ancora na estreita relação com o trabalho produtivo.

- As atividades coletivas dos professores e alunos devem ter um objetivo articulado a um projeto social, do qual ambos estão conscientes;

- As práticas educativas estão sempre subordinadas às práticas sociais mais amplas;

- O ensino e a aprendizagem estão submetidos a determinadas leis de cunho psicológico, social, cultural etc.;

- O ensino e a aprendizagem devem ser entendidos como um processo, o que pressupõe uma sucessão dinâmica.

Foi com esses pressupostos e tendo por princípio que a aprendizagem é algo a ser construído num contínuo processo de mediação, em que o professor é sujeito essencial e o aprendiz sujeito ativo, é que o curso foi projetado.

\section{O Curso de Formação Pedagógica: operacionalização}

A proposta de formação consistiu em oferta de encontros presenciais e atividades não presenciais, no total de 80 horas. Para o cumprimento do roteiro proposto, o curso foi elaborado em módulos:

1) Apresentação: GPS (Global Positioning Syste) - onde estamos e para onde queremos ir;

2) Competências do docente / Aspectos motivadores $x$ desmotivadores em sala de aula; 
3) Planejamento do ensino - criando rotas;

4) Princípios da oratória;

5) $\mathrm{O}$ ensino profissionalizante - Surgimento da Educação Profissional;

6) Metodologias de ensino e aprendizagem;

7) Psicologia do desenvolvimento e da aprendizagem;

8) Teorias da educação;

9) Educação inclusiva;

10) Tecnologia aplicada à educação e sistema de informação;

11) Relações interpessoais;

12) Avaliação do processo ensino aprendizagem.

A oferta do curso encontrou adesão bastante significativa por parte dos professores bolsistas do Pronatec-Cefores-UFTM. Isso pode ser constatado quando, inicialmente, foram propostas duas turmas de 20 pessoas, mas foram formados 3 grupos com mais de 90 professores inscritos, inclusive aqueles não vinculados ao Pronatec, pertencentes ao quadro efetivo do Cefores.

Foram, então, criadas três turmas, tendo em vista a disponibilidade de carga horária da equipe responsável e dos professores inscritos. Assim, o curso foi iniciado em abril de 2014, com duas turmas durante a semana, e outra turma, aos sábados, com previsão de término para outubro do mesmo ano.

\section{Resultados}

A adesão ao curso foi bastante significativa, conforme demonstrado pelo preenchimento de todas a vagas, inclusive com lista de espera. No entanto, na execução de fato, muitos professores que se inscreveram não puderam comparecer e justificaram que, apesar de serem ofertadas diferentes turmas, os horários entravam em choque com suas atividades profissionais. Assim, o curso foi iniciado com 3 turmas.

Como o curso foi planejado por uma equipe multidisciplinar, foi possível apreender diferentes olhares sobre a prática educativa, desde o 
processo de planejamento até a avaliação da aprendizagem, do curso, dos profissionais e da execução do programa como um todo. Cada encontro foi mediado por um membro da Equipe Multidisciplinar com maior conhecimento sobre a temática abordada.

A equipe psicopedagógica esteve durante todo o ano de 2014 avaliando o processo e fazendo as alterações de percurso, quando necessárias. À medida que a oferta do curso foi acontecendo, alguns professores desistiram e, entre as razões, identificamos: o contrato com o Pronatec-Cefores-UFTM foi finalizado ou os professores assumiram aulas no horário do curso. Assim, das efetivas 94 pessoas que iniciaram o curso, foram certificadas 70 pessoas.

Tendo em vista alguns cancelamentos de dias de aula por feriado ou indisponibilidade de salas, o curso durou até o final de novembro de 2014, quando, em uma atividade de encerramento, foi feita também a avaliação do curso.

Nas avaliações feitas pelos participantes, constatou-se que o curso foi de "grande valia" tido oportunidade de repensar a sua prática docente dessa forma. Aqueles que se viram como docentes pela primeira vez observaram que não imaginavam que a tarefa de ensinar tivesse as implicações que foram abordadas no curso. Registraram também que os saberes adquiridos já estavam sendo utilizados por eles ou seriam em breve.

É preciso registrar que alguns participantes que tiveram alta taxa de infrequência alegaram que o curso se tornou cansativo, demorou para acabar, mesmo que o temas abordados fossem importantes para a sua prática. Apesar de alertarem para isso, fizeram questão de indicar que o curso foi bem planejado, as aulas foram dinâmicas e que refletiram a realidade concreta.

Como um Programa de governo, o Pronatec foi sendo abandonado pelo executivo federal, especialmente a partir da queda do governo Dilma Roussef. Não foi possível continuar com a equipe psicopedagógica,

${ }^{4}$ Palavras dos próprios professores no formulário de avaliação. 
pois os recursos financeiros encaminhados se tornariam insuficientes para a proposta de execução Pronatec-Cefores-UFTM. A questão é que os professores e demais profissionais atuantes no Programa são contratados exclusivamente para a carga horária do curso ofertado. Assim, uma das críticas ao Programa é não prever carga horária para planejamento e avaliação. O que foi feito no Pronatec-Cefores-UFTM foi uma opção da gestão local, dentro das possibilidades reais de repasse orçamentário.

\section{Considerações finais}

A política educacional implantada via Pronatec se apresenta como programa integrador da política educacional para a educação profissional no país, assumindo, no tocante à formação da força de trabalho, uma estratégia para viabilizar as políticas macroeconômicas adotadas. Daí que a qualificação se impõe sobre a formação humana. Isso tem um significado que é a ampliação quantitativa dos anos de escolaridade básica e uma organização curricular voltada mais imediatamente para o desenvolvimento de capacidades técnicas e de uma nova sociabilidade relacionada às massas trabalhadoras.

Essa concepção, ainda que não assumida concretamente, motivou reformas educacionais que impulsionam este vínculo da escolarização ao sistema produtivo e, consequentemente, ao mercado. As consequências disso para os trabalhadores é uma formação educacional com limites bem definidos quanto à formação intelectual, ao seu preparo como força de trabalho, colocando em segundo plano a formação humana que desenvolve integralmente o indivíduo.

No âmbito do Cefores-UFTM, apesar dos revezes encontrados ao longo da oferta Pronatec-Cefores-UFTM, bem como os condicionantes intrínsecos à política, consideramos que a oferta do curso de Formação Pedagógica, aos professores bolsistas, foi uma oportunidade de refletir sobre os limites e as possibilidades no cotidiano da prática educativa.

No limite de um artigo, é impossível registrar as impressões, o aprendizado, as possibilidades de atuação dessa iniciativa. Assim, o trabalho desenvolvido 
transformou-se em projeto de tese, que está em desenvolvimento no Programa de Pós-Graduação em Educação da Universidade Federal de Uberlândia, linha de Trabalho, Sociedade e Educação.

\section{Referências}

ANTUNES, R. Adeus ao trabalho? (Ensaio sobre as metamorfoses e a centralidade do mundo do trabalho). São Paulo, SP/Campinas, SP: Cortez/Editora da Unicamp, 1995, $152 \mathrm{p}$.

ANTUNES, R. Os sentidos do trabalho: ensaio sobre a afirmação e negação do trabalho. 7 . ed. Sao Paulo: Boitempo, 2009. 259p.

ARAÚJO, R. M. de L. Desenvolvimento de competências profissionais: as incoerências de um discurso. 2001. 218f. Tese (Doutorado em Educação) - Universidade Federal de Minas Gerais, Belo Horizonte, 2001.

ARAÚJO, Romildo de Castro; FRANÇA, Robson Luiz de; LUCENA, Carlos. Trabalho e educação: formação humana e crise estrutural do capital. In: LUCENA, Carlos; LUCENA, Lurdes; BERNARDES, Elizabeth Lannes. Trabalho e educação: teoria e resistência. Uberlândia: Navegando Publicações, 2018.

BRASIL. MEC. PRONATEC. Programa Nacional de Acesso ao Ensino Técnico e Emprego. 2010. Disponível em: <http://pronatecportal.mec.gov.br/index.html> . Acesso em: 8 jul. 2014.

BRASIL. Programa Nacional de Acesso ao Ensino Técnico e Emprego. Lei no 12.513 de 26/10/2011. Institui o PRONATEC. Disponível em: <http://pronatecportal.mec.gov.br/ arquivos/lei_12513.pdf >. Acesso em: 10 maio 2014.

BRASIL . Palácio do Planalto. Discurso na cerimônia de sanção da lei que cria o programa nacional de acesso ao ensino técnico e emprego (Pronatec). Brasília, 26 out. 2011b. Disponível em: http://www2.planalto.gov.br/acompanhe-o-planalto/discursos/discursos-da-presidenta/discurso-da-presidenta-da-republica-dilma-rousseff-na-cerimonia-de-sancao-da-lei-que-cria-o-programa-nacional-de-acesso-ao-ensino-tecnico-e-emprego-pronatec-brasilia-df. Acessado em: 19 jul. 2016.

CEFORES, Pronatec-UFTM, Resolução No 62, de 11 de Novembro de 2011.

CEFORES. Projeto Pedagógico do Curso Redes de Computadores. 2016.

DEITOS, Roberto Antonio; LARA, Angela Mara de Barros; ZANARDINI, Isaura Monica Souza. Política de Educação Profissional no Brasil: aspectos socioeconômicos e ideológicos para a implantação do Pronatec. Educ. Soc., Campinas, v. 36, n. 133, p. 985-1001, out./dez., 2015 . 
IPEA. Instituto de Pesquisa Econômica Aplicada Texto para discussão. Pronatec: múltiplos arranjos a ações para ampliar o acesso à Educação Profissional - Brasília: Ipea , 2014. Disponível em: http://www.en.ipea.gov.br/agencia/images/stories/PDFs/TDs/td_1919. pdf Acesso em: 24 set. 2018.

LUCENA, C. A.; LOMBARDI. C. J.; PREVITALI, F. S. (Orgs.) . Mundialização do trabalho, transição histórica e reformismo educacional. Campinas - SP: Librum Editora, 2014. v.1.

PENA, G. A. de C. Formação docente e aprendizagem da docência: um olhar sobre a educação profissional. Educação em Perspectiva, Viçosa, v. 2, n. 1, p. 98-118, jan./jun. 2011. Disponível em: https:/educacaoemperspectiva.ufv.br/index.php/ppgeufv/article/ view/777/214. Acesso em: 22 set. 2018.

PREVITALI, F. S.. Novos contornos do trabalho, educação e alienação no século XXI. São Paulo: Xamã, 2013.v.1.

SALDANHA, L. de L. W. O PRONATEC e a relação Ensino Médio e Educação Profissional. IX Anped - Sul. Seminário de Pesquisa em Educação da Região Sul. 2012. http:// www.ucs.br/etc/conferencias/index.php/anpedsul/9anpedsul/paper/viewFile/1713/14 


\section{FORMAÇÃO CONTINUADA DE PROFESSORES E RELACOÕES ÉTNICO RACIAIS: QUESTÕES SOBRE A TEMÁTICA INDÍGENA NAS ESCOLAS}

Rogéria Moreira Rezende Isobe

Neide Borges Pedrosa

\section{Introdução}

Nas últimas décadas, a formação de professores e o desenvolvimento profissional dos docentes tem sido alvo de discussões no cenário das políticas educacionais e no ambiente acadêmico nacional e internacional, tendo em vista a construção de novos horizontes no campo educativo. Nóvoa (2009) menciona o relatório da OCDE (Organização para Cooperação e Desenvolvimento Econômico), publicado em 2005 - Teachers Matter - que ressalta "as questões relacionadas com a profissão docente como uma das grandes prioridades das políticas nacionais" (p. 12). O autor observa que nas últimas décadas foram produzidos inúmeros relatórios internacionais, artigos científicos, teses de doutoramento, discursos políticos, nos quais se nota um "consenso discursivo" (Nóvoa, 2009, p.12) sobre a necessidade de se redefinir os processos de formação de professores, tendo em vista uma efetiva mudança nas práticas escolares, de modo a responder aos inúmeros desafios da complexa sociedade do século XXI.

$\mathrm{O}$ autor adverte que o fato de se ter construído um discurso coerente e, em muitos aspectos, consensual, não significa que se tenha conseguido fazer aquilo que é proclamado, pois a inflação retórica sobre os professores e sua formação não é acompanhada por uma política de valorização do magistério e de sua autonomia profissional, ao contrário, o que se percebe é uma ampliação dos controles estatais sobre a prática docente. Nesse sentido, o autor afirma ser necessário: 
Construir políticas que reforcem os professores, os seus saberes e seus campos de actuação, que valorizem as culturas docentes, e que não transformem os professores numa profissão dominada pelos universitários, pelos peritos ou pela 'indústria do ensino'(Nóvoa, 2009 p. 16).

No Brasil, a preocupação com a formação de quadros para o magistério, no âmbito das políticas públicas, decorre da crescente demanda desses profissionais "oriunda da expansão da oferta da educação básica no Brasil, e da ameaça de futura escassez de professores em determinadas etapas de ensino em determinadas disciplinas ou áreas de conhecimento" (Oliveira; Duarte, 2014, p. 69).

Aliada a uma necessária política de valorização do magistério - condições de trabalho, salários e carreira -, a formação continuada é apontada como um dos elementos basilares na efetivação de mudanças nas práticas escolares, na perspectiva de uma educação que valoriza a diversidade, o conhecimento e a liberdade (Nóvoa, 2009 e 2013; Marin, 1995; Giovanni; Marin, 2014; Gatti, 2003; 2008).

Entre as questões amplamente discutidas sobre os processos de formação de professores, destaca-se a necessidade de construção de uma escola intercultural, com ênfase na diversidade cultural, que se apresente como possibilidade de superação das ambiguidades, conflitos e tensões advindas da cultura homogeneizadora e excludente da escola atual. Para Nóvoa (2009): "os professores reaparecem, neste início do século XXI, como elementos insubstituíveis não só na promoção das aprendizagens, mas também na construção de processos de inclusão que respondam aos desafios da diversidade" (p. 13).

De fato, historicamente a instituição escolar é herdeira de uma longa tradição de ensino etnocêntrico e ocidental, que subjuga e inferioriza a diferença com a legitimação de determinados modelos identitários, tidos como unívocos, eternos, universais (Silva; Moreira, 1995). O sistema educacional brasileiro e os processos tradicionais de formação de professores têm sido apontados, pois, pelas pesquisas acadêmicas assim como pelos movimentos sociais como lócus de reprodução das desigualdades 
sociais e raciais, reforçando atos de opressão, discriminação e preconceito existentes no conjunto de relações sociais mais amplas (Moreira; Candau, 2003).

Nessa conjuntura, questões relativas à diversidade das culturas hibridizadas passaram a ocupar mais espaço na produção acadêmica e na arena política brasileira, desencadeando a implementação de programas e ações de viés étnico nas escolas. $\mathrm{O}$ tema referente à diversidade apresenta-se como uma das dimensões da política afirmativa no campo educacional que envolve a busca da integração dos diferentes grupos sociais existentes, por meio da valorização de suas culturas. Nessa perspectiva, foi sancionada a Lei 11.645 de 2008:

[...] a Lei 10639 e, posteriormente, a Lei 11645, que dá a mesma orientação quanto à temática indígena, não são apenas instrumentos de orientação para o combate à discriminação. São também Leis afirmativas, no sentido de que reconhecem a escola como lugar da formação de cidadãos e afirmam a relevância de a escola promover a necessária valorização das matrizes culturais que fizeram do Brasil o país rico, múltiplo e plural que somos (Brasil, 2009, p. 5)

Com o intuito de combater preconceitos e discriminações que sofre a população negra e indígena no Brasil, a Lei 11.645 estabelece a obrigatoriedade do ensino das Relações Étnico-Raciais e de História e Cultura Afro-Brasileira e Africana e dos povos indígenas no Brasil, para todas as instituições de ensino, públicas e privadas, em todos os graus, da educação infantil ao ensino superior (Brasil, 2008). A data de publicação da lei evidencia que, até o final da primeira década do século XXI, aquelas populações vivenciaram cinco séculos de invisibilidade e negação de seus direitos sociais.

No que se refere à cultura indígena, é preciso considerar que, embora essa determinação legal represente uma conquista resultante de um longo processo de lutas para superar o preconceito e discriminação contra as populações indígenas, isso não significa a concretização de uma educação intercultural nos estabelecimentos de ensino, na medida em 
que a formação inicial dos professores contempla de forma incipiente o ensino dessa temática.

Nos últimos anos, houve um aumento gradativo da produção bibliográfica sobre a abordagem da temática indígena nas escolas (Bonin, 2006 e 2010; Grupioni, 1996; Bergamaschi, 2008; Bergamaschi; Gomes, 2012; Silva, 2012, entre outros). As investigações sinalizam o predomínio de concepções preconceituosas e imagens estereotipadas nas escolas, pois "dentro da sala de aula, os professores revelam-se mal informados sobre o assunto, e os livros didáticos, com poucas exceções, são deficientes no tratamento da diversidade étnica e cultural existente no Brasil" (Grupioni, 1996, p. 424). A temática indígena é abordada, pois, no ambiente escolar, de forma superficial, descontextualizada e marcada pelas visões da literatura romântica do século XIX, que representa o indígena idealizado como exótico ou em situações que o vitimizam.

A superação dessa problemática configura-se em um processo que deve ser construído por estudos culturais abrangentes, subsidiados por uma reflexão radical e rigorosa que permita a compreensão das raízes do problema e seus fundamentos, questionando-se as concepções do senso comum construídas historicamente, pois "é na cultura que se dá a luta pela significação, na qual os grupos subordinados tentam resistir à imposição de significados que sustentam os interesses dos grupos dominantes" (Vorraber Costa, 2002, p. 138).

As ações de formação continuada configuram-se, nessa conjuntura, em importante estratégia de construção de uma educação intercultural para que a temática das relações étnico raciais possa ser abordada numa perspectiva crítica, problematizadora, tendo em vista o reconhecimento e valorização da diversidade cultural brasileira bem como o respeito às diferenças dos saberes e modos de vida indígenas e não indígenas.

É nesse caminho de reflexões que se situa a experiência de formação continuada de professores desenvolvida no âmbito do projeto "Culturas e História dos Povos Indígenas” - CHPI/UFTM - desenvolvido com o objetivo de contribuir para a implementação qualificada da Lei 11.645/2008. O projeto foi realizado por docentes da Universidade Federal do Triângulo 
Mineiro, professores e tutores selecionados, no âmbito das ações preconizadas pela Rede Nacional de Formação Continuada dos Profissionais do Magistério da Educação Básica Pública (RENAFORM).

O objetivo deste trabalho é relatar a experiência de formação, destacando o perfil dos cursistas e a metodologia do curso, operacionalizado por meio duas atividades articuladas: (1) atividades de mobilização e articulação político-institucional; (2) atividades de formação desenvolvidas por meio de aulas presenciais e a distância, viagens programadas para realização de visitas a museus e comunidades indígenas e seminários temáticos com a participação de representantes indígenas provenientes de Rondônia.

\section{Atividades de mobilização e articulação político-institucional}

As mudanças no mundo contemporâneo conferem às Universidades um papel estratégico no desenvolvimento das sociedades. No Brasil, a Universidade Pública caracteriza-se como locus de produção e democratização do conhecimento bem como espaço plural e democrático de reflexão e crítica acerca dos diferentes processos societários. No cumprimento de seu compromisso social, a universidade deve promover uma articulação com a sociedade, na busca da construção de um projeto que permita, de forma efetiva, concretizar uma pauta de inclusão social: a formação cidadã e humanista, na perspectiva de desenvolvimento integral do ser humano.

Nessa perspectiva, a primeira frente de ação do projeto CHPI/ UFTM foi o desenvolvimento de ações para a articulação e mobilização de diversos atores sociais, buscando responder ao desafio de construir ações coletivizadas capazes de intervir de forma qualitativa na educação pública brasileira.

Mobilizar quer dizer "por em movimento", movimentar-se em favor de um propósito, uma campanha, ou seja, fazer que uma ou mais pessoas modifiquem o estado de acomodação para construir um novo cenário social. O conceito de "mobilização" - originário do Latim, mobilis - diz respeito àquilo que pode mudar de lugar. Dessa forma, a mobilização social permite a construção de um espaço de reflexões e questionamentos que levam 
as pessoas a pensarem no mundo não como algo a-histórico e definitivo, mas passível de mudanças, abrindo espaço para a visualização de múltiplas interpretações do mundo e a construção de novas representações sobre a realidade e novas identidades.

Para os teóricos Bernardo Toro e Nísia Werneck (2004), mobilizar é o ato de convocar vontades para atuar na busca de um propósito comum, compartilhando interpretações e sentido. É a partir deste sentido compartilhado que diferentes sujeitos ou setores da sociedade se reúnem para transformar determinados processos ou ações.

É importante ressaltar que um processo de mobilização não acontece espontaneamente, mas representa a iniciativa de pessoas que decidem agir, promovendo a participação do coletivo, em prol de um objetivo comum. Nesse sentido, a equipe do projeto realizou diversas visitas aos municípios circunscritos à região do Triângulo Mineiro. Foram realizadas reuniões com gestores municipais e sociedade civil, nos municípios selecionados, com a finalidade de apresentar a proposta de trabalho do projeto CHPI/ UFTM e estimular a mobilização das forças locais, ressaltando a importância da conjugação de esforços para atender as demandas de melhoria na qualidade do ensino em nível regional. Foram utilizadas, ainda, outras estratégias de articulação com os serviços/instituições dos municípios da área de abrangência, tais como: envio de ofícios para sensibilização e divulgação dos cursos, períodos de inscrição, fichas de inscrição, cronogramas, disponibilização das informações no site da UFTM e ampla divulgação por meio de cartazes, folders e nas emissoras de rádio locais.

Além disso, buscou-se realizar visitas nas escolas com o propósito de romper com a cultura do isolamento, propiciando o contato com os próprios docentes, apresentando novas perspectivas de formação de professores com a oferta de cursos gratuitos pela UFTM, tendo em vista a implementação qualificada da Lei 11.645/2008. Tais visitas apresentaram-se como espaços privilegiados de construção de um "sentido", um "propósito" consistente, capaz de fomentar parcerias e motivar ações integradas para o desenvolvimento das atividades de formação continuada aos professores da rede pública de ensino na região do Triângulo Mineiro. 


\section{Atividades de formação}

O projeto de formação teve como público alvo professores em exercício da Educação Básica da rede pública municipal de ensino. Foi desenvolvido no período de junho de 2014 a fevereiro de 2015, com 123 professores provenientes de seis municípios: Delta, Conceição das Alagoas, Planura, Pirajuba, Veríssimo (Minas Gerais) e Igarapava (São Paulo). Tais municípios são integrantes da área de abrangência da UFTM, devido à proximidade com a cidade de Uberaba, sede da instituição. Quanto ao número de habitantes, os seis municípios possuem a média de 13.038, sendo o número máximo 27.900 e mínimo 3.890 habitantes.

A proposta buscou, por um lado, oferecer um repertório conceitual e teórico que possibilitasse o desenvolvimento de uma educação intercultural nas escolas e, por outro lado, contribuir para a construção de uma cultura profissional para atuar na contramão dos paradigmas vigentes na sociedade atual: do individualismo e competição, para o coletivo e a cooperação; da rigidez, para a flexibilidade; do foco no indivíduo e na instituição, para o foco no trabalho colaborativo em equipe.

Não se tratou, portanto, de oferecer um curso de "capacitação" sobre as culturas e história dos povos indígenas, mas de realizar um processo de formação pautado nos pressupostos teóricos e metodológicos da pedagogia freireana, que preconiza a dimensão dialógica e processual da formação docente (Freire, 1991).

O processo formativo foi operacionalizado por meio de 3 (três) tipos de atividades articuladas: 1) curso de aperfeiçoamento com aulas presenciais e a distância; 2) seminários temáticos com a participação de representantes indígenas de diversas etnias; 3 ) viagens programadas para realização de visitas a museus e comunidades indígenas.

O curso de aperfeiçoamento foi estruturado em 3 módulos de 60 horas, perfazendo um total de 180 horas/aulas, desenvolvidas no período de junho/2014 a fev/2015. As atividades formativas ocorreram em dois polos: 1) Conceição das Alagoas; 2) Delta. Metodologicamente, o curso foi organizado em atividades presenciais (40h) e à distância (20h), 
operacionalizadas com carga horária de 2 horas e quinze minutos para cada módulo, e em cada mês. Essa carga horária foi oferecida a quatro turmas (30 a 31 alunos), concomitantemente. Os módulos se constituíram numa sequência didática, em que o/a ministrante retomava as atividades do módulo anterior e, portanto, se constituiu num todo articulado.

As atividades presenciais foram desenvolvidas por meio de aulas expositivas e dialogadas, associadas à utilização de recursos audiovisuais, palestras e oficinas. O processo formativo propôs, ainda, uma abordagem diferenciada de trabalho, contando com a colaboração de uma professora da etnia Xavante, proveniente do Estado do Mato Grosso - Parque Indígena do Xingu. A docente realizou palestras e oficinas favorecendo, dessa forma, o protagonismo indígena nos processos de revisão crítica dos estigmas e preconceitos que marcam uma sociedade etnocêntrica.

As atividades monitoradas à distância foram acompanhadas pelo professor responsável por ministrar a carga horária presencial, auxiliado pelo tutor. $\mathrm{O}$ projeto previa que as atividades à distância fossem realizadas com a utilização da plataforma Moodle (Modular Object-Oriented Dynamic Learning Environment), para que os cursistas tivessem oportunidade de entrar em contato com essa interface promotora do processo de ensino e aprendizagem. No entanto, diante da realidade encontrada, a operacionalização das atividades não foi realizada conforme previsto. Entre os problemas encontrados, destacam-se três questões principais: dificuldade de acesso a computadores; falta de habilidade em informática por parte de muitos cursistas (que gera insegurança e resistência ao uso das tecnologias digitais); instabilidade da internet.

A propósito dos problemas mencionados, Bonilla e Pretto (2007) afirmam que a dificuldade de acesso aos computadores ainda é uma realidade a ser superada para a vivência plena da cultura digital. Sobre a dificuldade dos cursistas no manuseio de forma correta e plena com a informática, Mattos e Chagas (2008) advertem que o simples acesso aos dispositivos de tecnologia não é condição suficiente para a construção da cultura digital, uma vez que, em nosso país, a exclusão digital está associada às desigualdades sociais, econômicas, culturais e regionais. Ao analisar os limites das políticas públicas de 
inclusão digital no Brasil, que priorizam medidas como doação de computadores e replicação de modelos de telecentros, os autores argumentam que é preciso considerar os termos qualitativos desse processo, pois a inclusão digital efetiva pressupõe a apropriação crítica e social das tecnologias digitais, ou seja, relaciona-se ao empoderamento do sujeito para a transformação de sua realidade.

Um complicador adicional encontrado na operacionalização das atividades à distância - e que também é um desafio para a inclusão digital - refere-se à instabilidade da internet nos polos de realização do curso. Sobre essa questão, Lemos e Marques (2012) defendem a criação de um plano nacional eficiente e igualitário na oferta de serviços de banda larga de internet, uma vez que tais serviços - atualmente ofertados por parte das operadoras - são extremamente precários em determinadas regiões e localidades do interior do país.

Diante do exposto, as atividades à distância foram desenvolvidas por meio da leitura e produção de texto, desenvolvimento de práticas pedagógicas, produção de material informativo para a utilização na sala de aula, de acordo com a realidade da escola e com os temas discutidos no módulo.

Outra atividade formativa foi a realização 3 (três) Seminários Temáticos, com objetivo de ampliar as informações e experiências relacionadas com a temática das culturas e história dos povos indígenas. Os Seminários consistiram em uma das estratégias de maior impacto do projeto, visto que envolveu vários segmentos da rede de ensino, comunidade acadêmica, gestores municipais e sociedade civil. As palestras contaram com a participação de representantes das etnias Gavião-Ikolen e Arara-Karo - que vivem na Terra Igarapé Lourdes do Município de Ji-Paraná, em Rondônia - e também com representantes da etnia Xavante, bem como uma representante da etnia Potiguara, do litoral norte paraibano.

Os palestrantes apresentaram diversas fotografias e vídeos sobre as experiências realizadas nas aldeias indígenas, contribuindo, dessa forma, para desconstruir representações e estereótipos de cunho eurocêntrico que se arrastam ao longo da história. Em tais representações, reiteradas nos livros didáticos das escolas brasileiras, esses grupos étnicos são 
personagens de um passado remoto, no qual supostamente deveriam viver frequentemente nus, caçando e pescando nas matas, para a preservação de suas culturas. Nessas imagens caricaturais, reproduzem-se a dicotomia entre "índios puros", vivendo nas matas, versus "índios contaminados pela civilização". A propósito dessa questão, são pertinentes as observações de Bonin (2010)

Os mais de 230 povos indígenas que, na atualidade, vivem em terras brasileiras, falantes de mais de 180 línguas distintas, são lembrados como povos do passado, aprisionados em representações fixas, ou recordados por algumas contribuições e marcas que deixaram, na chamada cultura nacional, aspectos que, em geral, reconhecemos como parte do folclore brasileiro [...] Um dos efeitos de tais representações é a produção de um lugar para eles sempre no passado [...] E porque são vistos como sujeitos genéricos, amalgamados à natureza, causa-nos grande estranhamento a presença de indígenas nas feiras, participando de atividades comerciais, nas ruas de centros urbanos (p. 78).

No âmbito de um modelo escolar fundamentado historicamente na tradição etnocêntrica ocidental, a divulgação e valorização das experiências culturais de diversas etnias foram de extrema relevância para o desenvolvimento de diálogos interculturais nos processos de formação continuada de professores. As palestras proferidas por representantes de diversas etnias indígenas contribuíram, pois, para a problematização da situação de invisibilidade e discriminação das sociedades indígenas no Brasil fomentando, a partir de reflexões sobre identidade e etnia, direito à diferença e conhecimento da diversidade, da história e da cultura indígenas, a valorização e reconhecimento dessas populações na perspectiva de uma educação intercultural (Bergamaschi; Gomes, 2012).

Além dos seminários, foram realizadas 3 (três) atividades formativas complementares: 1) visita ao Acervo Arqueológico do município de Nova Ponte - MG, constituído de painéis explicativos, peças e vestígios arqueológicos de materiais de culturas pré-históricas e indígenas encontrados em 120 sítios arqueológicos e 59 locais com indícios de ocupação indígena da 
região do Triângulo Mineiro; 2) visita ao Memorial dos Povos Indígenas em Brasília, que abriga um acervo de 380 peças de artesanato indígena, doado pelo casal de antropólogos Darcy e Berta Ribeiro, e reunido em mais de 40 anos de pesquisa pelo interior do Brasil. Ressalta-se que essa é uma das raras instituições que contam com a participação dos próprios índios em sua gestão; 3) Viagem a Rondônia para visita às comunidades indígenas das etnias Gavião-Ikolen e Arara-Karo, na Terra Igarapé Lourdes do Município de Ji-Paraná. A viagem foi realizada por ônibus disponibilizado pela UFTM e configurou-se em uma rica experiência de diálogo intercultural e conhecimento sobre saberes e fazeres específicos daquelas comunidades, tendo em vista o combate ao preconceito e superação da visão homogeneizante a respeito das culturas indígenas que ainda predomina na maioria das concepções e práticas escolares.

\section{Considerações finais}

A experiência corrobora o entendimento de que a desconstrução gradual de preconceitos e estigmas com a cultura e história dos povos indígenas nas escolas exige a formulação de estratégias de formação continuada de professores, bem como a ampliação de espaços de debate e reflexão que fomentem o protagonismo de povos e lideranças indígenas nesse processo. Ninguém melhor que um indígena para falar de suas experiências históricas com outras sociedades e culturas e dos desafios enfrentados na luta pela garantia das terras e pela conquista de direitos civis, políticos, socioeconômicos e culturais.

Os resultados do projeto de formação CHPI-UFTM e as perspectivas indicadas neste relato de experiência configuram-se em sínteses provisórias sobre a problemática analisada, pois a consolidação de uma educação intercultural nas escolas brasileiras supõe a construção permanente de ações intersetoriais e integradas que deverão ser delineadas ao longo da experiência coletiva, pois nenhuma ação isolada tem a possibilidade de melhorar a qualidade do ensino público em nosso país. 
Ademais, é preciso considerar que as ações de formação continuada, desenvolvidas no âmbito das políticas com foco na valorização do magistério, só serão efetivas se contemplarem outros aspectos de profissionalização da carreira do magistério, tais como o salário, as condições de trabalho e a progressão na carreira (Freitas, 2003). Caso contrário, tais ações podem gerar apenas uma intensificação do trabalho docente e responsabilização dos professores acerca dos problemas escolares, contribuindo ainda mais para os processos de degradação profissional do magistério público.

\section{Referências}

BRASIL. Lei 11.645 de 10 de Março de 2008. Diário Oficial da União, Poder Executivo, Brasília, DF, 2008. Disponível em: http://www.planalto.gov.br Acesso em: 7 mar.2016.

BRASIL. Plano Nacional das Diretrizes Curriculares Nacionais para a Educação das Relações Étnico-Raciais e para o Ensino de História e Cultura Afro-brasileira e Africana. Brasília: SECAD/ SEPPIR, junho, 2009. Disponível em: http://www.acaoeducativa. org.br/fdh/wp-content/uploads/2012/10/DCN-s-Educacao-das-Relacoes-Etnico-Raciais.pdf Acesso em: 15 ago. 2018.

BERGAMASCHI, M. A. (Org.). Povos indígenas e educação. Porto Alegre: Mediação. 2008.

BERGAMASCHI, M. A; GOMES, L. B. A Temática Indígena na Escola: ensaios de educação intercultural. Currículo sem Fronteiras, v. 12, 2012, p. 53-69.

BONILLA, M. H. S.; PRETTO, N. L. Formação de professores: as TICs estruturando dinâmicas curriculares horizontais. In: ARAÚJO, B.; FREITAS, K. S. Educação à distância no contexto brasileiro: experiências em formação inicial e formação continuada. Salvador: ISP/UFBA, 2007. p. 73-92.

BONIN, I. T. Problematizando narrativas sobre os povos indígenas: um olhar sobre o 'descobrimento', o 'encontro harmonioso' e outras histórias contadas na escola. Ciências Humanas em Revista, São Luís, v. 4, n. 1, junho, p. 61-72. 2006.

BONIN, I. T. Povos indígenas na rede das temáticas escolares: o que isso nos ensina sobre identidades, diferenças e diversidade? Currículo sem Fronteiras. v.10, n. 1, p. 133-146, jan/ jun 2010 .

FREIRE, P. Educação como prática da liberdade. 20. ed. São Paulo: Paz e Terra, 1991. 218p.

FREITAS, H. C. L. Certificação docente e formação do educador: regulação e desprofissionalização. Educação e Sociedade, Campinas, v.24, n.55, p. 1095-1124, dezembro. 2003. 
GATTI, Bernadete Angelina. Formar os professores: velhos problemas e as demandas contemporâneas. Revista da FAEEBA: Educação e Contemporaneidade. Salvador, v. 12, n. 20, p. 473-477, 2003.

GATTI, Bernadete Angelina. Análise das políticas públicas para formação continuada no Brasil, na última década. Revista Brasileira de Educação, Rio de Janeiro, v. 13, n. 37, jan./ abr. 2008. Acesso em: 28 jul.2016.

GIOVANNI, L. M; MARIN, A. J. Professores iniciantes: diferentes necessidades e diferentes contextos. Araraquara: Junqueira e Marin, 2014.

GRUPIONI, L D B. (Org.). A temática indígena na escola: novos subsídios para professores de $1^{\circ} 2^{\circ}$ graus. MEC, Brasília, 1996.

LEMOS, A.; MARQUES, F. P.J. A. O plano nacional de banda larga brasileiro: um estudo de seus limites e efeitos sociais e políticos. Revista da Associação dos programas de Pós-Graduação em Comunicação/ECompós, Brasília, v. 15, n. 1, jan./abr. 2012.

MARIN, A. J. Educação continuada: introdução a uma análise de termos e concepções. São Paulo: Papirus, (Cadernos CEDES 36: Educação Continuada, p.13-20), 1995.

MOREIRA, A. F. B. e CANDAU, V. M. Educação escolar e cultura(s): construindo caminhos. Rev. Bras. Educ. n.23, Rio de Janeiro, maio/ago. 2003, p 156-168.

MATTOS, F. A. M. e CHAGAS, G. J. N. Desafios para a inclusão digital no Brasil. Perspectivas em ciência da informação. v.13, n.1, jan./abr. 2008, p. 67-95.

NÓVOA, A. Professores: Imagens do futuro presente. Lisboa: Educa, 2009.

NÓVOA, A. Para uma formação de professores construída dentro da profissão. Lisboa: 2013. Disponível em: http://www.revistaeducacion.educacion.es/re350/re350_09por.pdf Acesso em: 8 out. 2018.

OLIVEIRA, D. A.; DUARTE, A. W. B. Valorização profissional docente nos sistemas de ensino de Minas Gerais e Pernambuco. Práxis Educacional. Vitória da Conquista, v. 10, n. 17, jul./dez. 2014, p. 67-97.

SILVA, M. P. A diversidade étnico-racial na escola e a temática indígena em questão: discutindo políticas públicas para a efetivação da lei 11.645/08. IV Encontro de Pesquisa Educacional em Pernambuco - EPEPE, Caruaru, set. 2012.

SILVA, T. T.; MOREIRA, A F. B. (Orgs.). Territórios contestados. O currículo e os novos mapas políticos e culturais. Petrópolis: Vozes, 1995.

TORO,J. B.; WERNECK, N. M. D. Mobilização Social: Um modo de construir a democracia e a participação. Belo Horizonte: Autêntica, 2004.

VORRABER COSTA, M. V. Poder, discurso e política cultural: contribuições dos Estudos culturais ao campo do currículo. In: LOPES, A. C.; MACEDO, E. (Orgs.). Currículo: debates contemporâneos. São Paulo: Cortez, 2002. 



\section{POLITICAS DE FORMAČ̃̃ INICIAL DE PROFESSORES: EXPEŔIÉNCIAS DO PIBID E A PRÁXIS DOCENTE ${ }^{1}$}

Leonice Matilde Richter

Maria Célia Borges

\section{Introdução}

As autoritárias ${ }^{2}$ e aceleradas mudanças nas políticas públicas de educação, em curso no país, demarcadas especialmente a partir do impeachment da Presidente Dilma Rousseff (31 de agosto de 2016), apontam a necessidade de debates, análises e, mais do que nunca, ações no sentido de resistir e encontrarmos alternativas diante das afrontas aos direitos da educação pública de qualidade. No âmbito da formação de professores, o Programa Institucional de Bolsas de Iniciação à Docência (Pibid) é um dos programas, dentre outros, ameaçado de extinção, que passa por um

\footnotetext{
${ }^{1}$ Este texto foi apresentado como painel no XIX ENCONTRO NACIONAL DE DIDÁTICA E PRÁTICAS DE ENSINO (Endipe-2018), realizado em Salvador, Ba.
}

${ }^{2}$ Em relação às ações autoritárias e intransigentes em curso, especialmente da PEC no 241/2016 (55/2016), observamos a adoção de uma política tributária regressiva e recessiva, buscando enxugar o Estado nas áreas sociais, que põe em risco a vida de milhões de brasileiros nos próximos 20 anos. Assim, essas ações estão integradas ao desmonte dos princípios da Constituição Federal de 1988 e do Estado brasileiro, e visam à eliminação de direitos sociais e políticos da chamada "Constituição cidadã", direitos outrora conquistados e que estão sendo perdidos. Os gastos com políticas públicas que visavam distribuir renda e remunerar, mesmo que indiretamente, os trabalhadores, efetuados a partir do governo Lula (2003-2010), estão sendo substituídos pela opção do congelamento, redução e remuneração do serviço da dívida pública, crescendo assustadoramente. O Estado está endividado não para financiar as políticas públicas, e sim remunerar e investir no capital produtivo e especulativo, especialmente por meio do pagamento de juros da dívida. Nesse sentido, as despesas primárias, materializadas em políticas públicas de previdência, educação, saúde, moradia, dentre outros, que cumprem de fato as funções do Estado, são as mais visadas e afetadas. $\mathrm{O}$ governo faz opção por utilizar o fundo público para remuneração do capital, restringindo as políticas públicas que distribuem riqueza e aumentam a rede de proteção social. Nesse contexto, o Estado assume a perspectiva de redução e de corte em termos de investimento público, com sérios prejuízos. Entendemos a situação dentro de uma lógica regressiva em termos de crescimento econômico, o que deve trazer graves consequências para o Brasil, na medida em que deve manter a economia em recessão. (Borges; Ribeiro; Richter, 2018) 
processo de reformulação por meio do Edital da Capes 07/2018, publicado concomitantemente ao Edital 06/2018, que regulamente o Programa de Residência Pedagógica e que absorve cinquenta por cento das bolsas destinadas ao Pibid ${ }^{3}$.

Os editais citados foram elaborados sem a participação da comunidade acadêmica envolvida com o Pibid, desconsiderando o conhecimento produzido pelo programa ao longo de uma década, que garantiu significativa experiência e análise crítica por parte das universidades e Educação Básica. Quanto ao Programa de Residência Pedagógica, este incorpora os objetivos da Base Nacional Comum Curricular, a qual foi aprovada em 2017 com fortes advertências por parte dos profissionais da educação. Assim, entendemos a importância da análise do trabalho até aqui desenvolvido no Pibid, com a divulgação das características, fundamentos e princípios que o orientaram, e com a respectiva análise de seus impactos na formação docente.

De tal modo, o presente artigo tem como campo empírico o Subprojeto Gestão Escolar do Curso de Pedagogia da Faculdade de Ciências Integradas do Pontal (Facip) da Universidade Federal de Uberlândia (UFU), que iniciou suas atividades em 2012, em duas escolas do município de Ituiutaba/MG, com a participação de 14 bolsistas, 2 supervisoras e 2 coordenadoras. Tem por objetivo analisar os impactos desse subprojeto na formação dos/as licenciandos/as envolvidos/as. Para tanto, assume como material de análise documental os diferentes registros e dados gerados pelos/as bolsistas ao longo dos últimos dois anos no projeto, considerando que a dinâmica de trabalho do Pibid/Gestão envolveu diagnóstico da escola em geral e, especificamente, da gestão das escolas por meio de questionários, entrevistas, observações e análise documental; planejamento dos projetos

\footnotetext{
${ }^{3} \mathrm{O}$ Programa Institucional de Bolsa de Iniciação à Docência - PIBID foi regulamentado em 24 de junho de 2010, através de publicação no Diário Oficial da União - DOU, decreto $\mathrm{n}^{\circ} 7.219$, assinado pelo então Presidente Luiz Inácio Lula da Silva e pelo Ministro da Educação, Fernando Haddad. É desenvolvido pelo Ministério da Educação e tem por finalidade apoiar a iniciação à docência de estudantes de licenciatura nas universidades brasileiras, com o fortalecimento da sua formação para o trabalho nas escolas públicas. $\mathrm{O}$ Programa oferece bolsas, distribuídas nas diversas áreas dos cursos de licenciatura oferecidos pela Universidade, para estudantes e professores desses cursos e também para professores das escolas participantes do Programa. Mais informações no site: (http://www.prograd.ufu. $\mathrm{br} /$ servicos/pibid)
} 
de intervenção e dos planos de atividades, com linhas de ação definidas pelo mapeamento da realidade. Neste artigo, analisamos principalmente a formação dos/as licenciandos/as no processo de elaboração e desenvolvimento de dois projetos efetivados em 2017, um com foco na "participação estudantil" e outro na "formação de professores/as".

\section{A formação inicial de professores/as por meio da práxis}

O ser humano, ao elaborar (na e em atividade) os meios para a sua existência, produz a própria vida material e, assim, constitui uma consciência comum. Para Vázquez (1977, p.8), sem transcender os limites dessa consciência, "não só é impossível uma consciência filosófica da práxis, como também uma práxis que se eleve a um nível superior - isto é, criador". Para chegarmos a uma verdadeira concepção filosófica da práxis, é necessário apresentá-la intimamente vinculada ao conceito de criação. Assim, no campo da docência, é necessário o/a professor/a se constituir em práxis, colocando a prática como fundamento do conhecimento e o conhecimento como fundamento da prática humana.

A perspectiva formativa do Pibid é provocar o diálogo com a realidade das escolas públicas no início da formação, com a orientação do/a profissional da universidade e de profissionais das escolas de educação básica. Esse é o indicador de uma política importante para o enfrentamento da histórica formação fragmentada de professores/as no país. No entanto, ao acompanhar a vivência do Pibid/Gestão e a análise do processo formativo dos/as bolsistas, observamos seus limites e possibilidades.

A análise condutora neste trabalho pauta-se no material produzido pelo Pibid/Gestão, organizado em dois projetos: "Participação Estudantil" e "Formação de Professores". No que se refere ao projeto Participação Estudantil, é válido saber que foi desenvolvido metodologicamente pelos/ as bolsistas por meio de rodas de conversa, teatros, reuniões, jogos, cordéis, raps, debates com gremistas e outras propostas. Tais atividades provocaram, no grupo de bolsistas, uma constante inquietação pela dimensão teórica. Assim, o estudo de referenciais teóricos era, em grande medida, 
uma necessidade do grupo, o que gera uma relação particular na formação desses/as estudantes. A dedicação do estudo teórico ocorreu desde a reflexão mais ampla sobre a participação estudantil até o estudo, com os/as estudantes da escola, sobre o estatuto do grêmio.

Esse processo permanente de estudo dialogava com o processo de planejamento e intervenção nos projetos. $\mathrm{O}$ acompanhamento da inscrição de chapas, eleição do grêmio da escola até o apoio às primeiras atividades realizadas pela diretoria do grêmio eleita, configurou um dos grandes desafios, tanto para os estudantes da escola quanto para os/as bolsistas do Pibid, haja vista a cultura, segundo a qual, na escola, as decisões raramente são protagonizadas por esses sujeitos.

Vale destacar que foi com base na reflexão da realidade da escola que os/as bolsistas elaboraram o projeto de intervenção; no caso, uma importante frente foi a implementação do Grêmio Estudantil. A busca pela fundamentação teórica foi ao encontro dos ditames das leis, com o respaldo do Artigo 14, da Lei de Diretrizes e Bases da Educação Nacional (LDB, 9394/96), onde delibera que os sistemas de ensino definirão as normas da gestão democrática do ensino público, considerando as suas peculiaridades, e devem garantir, dentre outros aspectos, a participação da comunidade escolar e local em conselhos escolares ou equivalentes. Nessa seara, o grêmio é estratégia central para garantir tanto a participação estudantil quanto a formação de cidadãos socialmente participativos.

A participação dos estudantes em lutas históricas, desde o âmbito das políticas públicas de educação, à dinâmica das instituições escolares ou do espaço mais micro da sala de aula, foi apontada nos registros reflexivos dos/as estudantes como elemento que permitiu ao grupo uma identificação e o sentimento de pertencimento, que levou inclusive estudantes envolvidos no Pibid a entrarem, no âmbito do curso de Pedagogia, em espaços políticos como a Diretório Acadêmico. A demanda pela participação dos diferentes grupos (seja de estudantes, professores, famílias, Estado...) no debate acerca de qual educação atende às nossas expectativas educacionais acompanha um processo de luta e disputa travada em uma sociedade historicamente marcada pela diferença e exclusão, na qual, via de regra, um pequeno grupo 
decide em nome da maioria. Essa lógica centralizadora do poder envolve diferentes instâncias, em um sentido verticalizado da estrutura educacional do nosso país. O processo formativo político, por meio dos temas do Pibid/ Gestão, provocou o envolvimento nessa importante dimensão da formação docente.

Os/as bolsistas identificaram que foi em função de muita resistência e luta que tivemos conquistas históricas em direção à gestão democrática. Constataram, na Constituição Federal, de 1988, no Artigo. 206, que o ensino deve ser ministrado com base em princípios de pluralismo de ideias, de concepções pedagógicas e da gestão democrática do ensino público. Direito este retomado na LDB (9.394/1996):

Art. 13. Os docentes incumbir-se-ão de: I - participar da elaboração da proposta pedagógica do estabelecimento de ensino; Art. 14. Os sistemas de ensino definirão as normas da gestão democrática do ensino público na educação básica, de acordo com as suas peculiaridades e conforme os seguintes princípios: I - participação dos profissionais da educação na elaboração do projeto pedagógico da escola; II - participação das comunidades escolar e local em conselhos escolares ou equivalentes. Art. 15. Os sistemas de ensino assegurarão às unidades escolares públicas de educação básica que os integram progressivos graus de autonomia pedagógica e administrativa e de gestão financeira, observadas as normas gerais de direito financeiro público (Brasil, 1996).

Através de fichamentos e artigo os/as bolsistas estabeleceram relação entre o contexto da aprovação da LDB e a gestão do Estado brasileiro que foi marcado por interesses e princípios neoliberais que, dentre outros, apontam a redução do Estado no campo das garantias sociais e assumem intensamente o mercado como modelo para a gestão pública. De tal modo, princípios - como a participação democrática - são negados, especialmente, ao serem reduzidos à mera transferência de responsabilidades do Estado para as escolas.

A categoria "força da resistência dos estudantes em diferentes momentos históricos do país" tomou relevo perante o interesse dos/as 
Pibidianos/as. O olhar atento à realidade atual mobilizou o diálogo com o momento político que estamos vivendo no país, sobretudo na atuação dos/as estudantes espalhados/as por todo o Brasil contra as medidas de austeridade do Governo. Assim, podemos dizer da importância do tema da participação estudantil, não apenas no contexto das escolas envolvidas no Pibid, mas também na vida política desses/as professores/as em formação.

A afirmação da escola como espaço verdadeiramente público passa pela constituição de uma cultura democrática que valorize os princípios da participação, da autonomia, do pluralismo, dos conselhos e da transparência nas práticas escolares. Segundo Araújo (2009), a participação de todos/as ao redor da escola e a transparência são aspectos importantes contra relações impostas e hierarquizadas. Por outro lado, a democratização é um processo que não ocorre espontaneamente, devendo ser impulsionado e construído em diferentes instâncias que primam pela gestão democrática. Concordamos com Araújo (2009) sobre a necessidade de viabilizar canais que estimulem a presença e interferência dos/as estudantes no direcionamento das questões políticas e pedagógicas da escola, pois é nessa vivência democrática que os/as estudantes se constroem como sujeitos críticos, autônimos e que interferem na vida pública. "A democratização da escola não é tarefa fácil, envolve as múltiplas relações com os diferentes sujeitos sociais, bem como passa pela afirmação e pela criação de espaços de participação dos alunos nas discussões políticas e pedagógicas da escola" (Araújo, p.258).

A experiência do Pibid/Gestão, ora em análise, oportunizou o aprendizado da participação por meio de uma gestão compartilhada na escola. Consideramos esse fato como um importante começo para o exercício da práxis democrática. Na gestão democrática, os canais de participação devem ser ampliados, embora a efetivação da participação dos discentes nos grêmios estudantis, conselhos de classe, assembleia geral da escola e projeto político pedagógico, dentre outros, encontre limites para 'sair do papel'.

Contudo, os/as pibidianos, ao longo do projeto, muitas vezes, se desestimularam diante da dificuldade em provocar a participação estudantil no contexto escolar, dada como um direito, mas, ainda, distante da nossa cultura e prática educacional. Dentre as grandes dificuldades está a própria 
concepção pedagógica, segundo a qual os/as discentes são considerados indivíduos passivos que não podem ou nada têm a contribuir com as decisões, sejam de natureza administrativa ou pedagógica.

Outrossim, essa vivência democrática é um processo fundamental para a formação política pedagógica. A escola, lócus de realização do projeto, não tinha uma história de reflexão ou demanda dos/as estudantes para a criação do grêmio. Os/as licenciandos/as, definiram que, dentre as primeiras ações necessárias, seria importante provocar o tema na escola e colaborar com a elaboração de conhecimentos por parte dos/as estudantes da instituição sobre o assunto. Assim, o grupo poderia se posicionar acerca do desejo ou não da implementação do grêmio.

Das diversas atividades realizadas pelos/as bolsistas, destacamos, para análise deste trabalho, os registros das rodas de conversa, que contou com a participação de convidados/as externos para discussões sobre o grêmio e o seu papel na escola; o mapeamento das escolas da cidade que possuíam grêmio; e os registros do diálogo com os/as gremistas do Instituto Federal do Triângulo Mineiro (IFTM). As estratégias metodológicas dos/as pibidianos/as despertou o interesse na escola, pois os gremistas foram vistos como exemplo e inspiração e, após esse movimento, foi notório o entusiasmo dos/ as estudantes das escolas. Curiosos/as e questionadores/as, iniciaram conversas sobre o desejo de criar o Grêmio e avaliar seus impactos num projeto de escola desejada pelos/as estudantes. Dentre outras estratégias, destacamos a peça teatral e um cordel realizados pelos/as estudantes e pibidianos/ as. Os/as estudantes elaboraram e encenaram para os/as colegas da escola o conhecimento construído e agora partilhado por meio da linguagem cênica. Destaca-se no roteiro:

Personagem 1: Tem gente aqui que acha que o Grêmio é só pra promover festinha na escola. Personagem 2: Grêmio estudantil é um espaço de discussão, de ação e luta em que os estudantes se organizam por eles mesmos na escola, sem depender de mais ninguém, nem precisa pedir autorização. Além de ter papel facilitador para a comunicação entre o colégio e os estudantes, o grêmio representa de forma geral um 
jeito de fazer democracia com responsabilidades. [....] Personagem 1: Grêmio serve para os estudantes discutirem e organizarem ações sobre aquilo que lhes interessa dentro e fora da escola. Fazer coisas juntos e levar propostas e reivindicações para a direção e os professores. (Pibid/ Gestão, 2017)

O cordel com o tema "Por que ter participação na escola?" foi debatido com os/as estudantes, evidenciando a formação da práxis criativa. Ao longo desse trabalho a avaliação constante do desenvolvimento do projeto levou a muitos processos de autoavaliação dos/as pibidianos/as, assim como a muitos conflitos entre os/as integrantes do grupo, conforme os registros em atas das reuniões semanais.

Observamos que o envolvimento dos/as licenciandos/as com o programa e a formação era manifestado em graus diferentes, o que foi gerando articulações dos membros em pequenos grupos. Esse fato foi objeto de debate sobre o sentimento de pertencimento, de respeito às ideias particulares e mesmo a falta de compromisso diante do trabalho coletivo. Esse foi um processo de formação significativa dos/as bolsistas do Pibid do curso de pedagogia.

\section{A formação de professores/as como campo de atuação do PIBID/ gestão}

Nas últimas décadas do século XX, a profissão docente enfrentou uma série de problemas, como a desvalorização salarial, o não reconhecimento social e, atualmente, depara-se com algumas contradições; de um lado, os/as docentes “[...] são vistos com desconfiança, acusados de serem profissionais medíocres e de terem formação deficiente", de outro, são “[...] elementos essenciais para a melhoria da qualidade de ensino e para o progresso social e cultural” (Nóvoa, 1998, p. 34). A problemática pode ser compreendida pela ideia comumente divulgada de que a educação de qualidade transformará a realidade do país, cabendo ao/à professor/a a responsabilidade de cumprir essa tarefa. 
Fernández Cruz afirma que a satisfação profissional do/a professor/a interfere na sua prática e, dentre outras necessidades, destaca o peso do sucesso do/a estudante, que significa o sucesso de seu trabalho. Afirma, desse modo, que

Sus resultados demuestran la falta de significatividad entre ambos constructos o como la satisfacción profesional de los directivos no está relacionada con el prestigio que pueda proporcionar ocupar el cargo, y sí con aspectos directamente relacionados con la enseñanza como el éxito del alumnado del Centro (2006, p. 113).

Por isso, acredita-se que o/a docente se sinta valorizado/a quando lhe é dada a oportunidade de aprender mais e, dessa forma, melhorar a sua atuação pedagógica. Nessa direção, García (1999) resgata contribuições acerca do conceito da palavra formação e sintetiza que formação não é o mesmo que ensino, treino ou educação; é um processo amplo que perpassa por questões pessoais de desenvolvimento humano; e está diretamente associado à disposição e capacidade do indivíduo em aprender. Para o autor:

[...] para se dar sentido à formação de professores, não se pode fazer derivar o seu corpo conceptual do conceito de ensino por si próprio. Ensinar, que é algo que qualquer um faz em qualquer momento, não é o mesmo que ser um professor. Existem outras preocupações conceptuais mais vastas que contribuem para configurar o professor: ser professor implica lidar com outras pessoas (professores) que trabalham em organizações (escolas) com outras pessoas (alunos) para conseguir que estas pessoas aprendam algo (se eduquem) [...] (Floden, Buchmann, 1990 apud Garcia, 1999, p. 23-24).

Para o autor, a formação de professores/as é área de conhecimento, de investigação, de propostas teóricas e práticas; contempla as formações inicial, continuada e o exercício docente; é um processo coletivo e individual; e está relacionado às experiências de aprendizagem que promovem reflexão e ação para com o ensino, escola, estudante, currículo, qualidade da 
educação, dentre outros aspectos. Assim, a formação de professores/as deve pautar-se pela inter-relação de fatores teóricos, técnicos, éticos, políticos, de experiência e identidade docente. $\mathrm{O}$ desenvolvimento profissional do/a professor/a é fator de interferência nas práticas de ensino, no desenvolvimento dos/as estudantes e nas crenças e atitudes docentes (García, 1999).

Nessa perspectiva, os/as bolsistas do Pibid/Gestão, em suas análises, perceberam a importância de a Gestão Escolar estar muito atenta e cuidadosa quanto ao processo formativo significativo dos/as docentes da escola, com temas caros à realidade vivida por eles/as.

No projeto de formação de professores/as, os/as pibidianos/as realizaram encontros, aos sábados, com os/as docentes, discutindo temas elencados pelos/as profissionais da escola. Planejaram metodologias como rodas de conversa, filmes, palestras, minicursos e oficinas envolvendo temas como as avaliações internas e externas, relação família e escola, matrizes de referência, Plano de Desenvolvimento Individual do aluno (PDI), Método clínico de Piaget, Fundamentos da gestão democrática, reestruturação do Projeto Político Pedagógico da escola, relação docente/estudante, relação escola/sociedade, dentre outros.

A formação continuada dos/as professores/as da Educação Básica tem sido um desafio constante e, no âmbito do Pibid/Gestão, essa foi outra importante ação, metodologicamente organizada em parceria com a escola.

Ao avaliarmos os planos e as atividades desenvolvidas pelos/as bolsistas, fica evidente um processo significativo de formação inicial dos/as licenciandos/as e, paralelamente, de formação continuada dos/as professores da Educação Básica. Nesse prisma, tanto a formação inicial quanto a continuada configurou-se em espaço fértil e fecundo de análise, fundamentada e sustentada por estudos teóricos acerca da organização do trabalho escolar, para, a partir desse movimento, construir alternativas pedagógicas, em um processo de ação-reflexão-ação. Assim, estamos de acordo que a formação do/a professor/a ocorre em um continuum porque, como sujeitos inacabados, não paramos de aprender. Já disse Paulo Freire, “[...] quem ensina aprende ao ensinar e quem aprende ensina ao aprender" (Freire, 1996, p.25). 
De tal modo, nos encontros de formação um aspecto relevante foi o cuidado dos/as Pibidianos/as em não privilegiar as discussões apenas acerca dos processos técnico-metodológicos. Consideraram, também, a falta de estrutura e de material didático-pedagógico, o cansaço e desgaste entre os/ as profissionais, o número de jornadas de trabalhos dos/as docentes, dentre outras variáveis que interferem na organização da formação continuada. Os/as bolsistas registraram, ainda, a grande diferença na participação dos/ as docentes, alguns/as fortemente comprometidos/as e outros que assumem posturas resistentes.

Encontramos nos registros dos/as bolsistas reflexões acerca dos desafios econômicos, curriculares, valorização docente, questão de gênero, conscientização social, percebidos como elementos que envolvem a formação contínua dos/as docentes. Observamos que os/as bolsistas desenvolveram consciência histórica, tendo clareza de que, no Brasil, a história da formação dos/as professores/as demonstra sucessivas mudanças, com características recorrentes de descontinuidade.

Portanto, faz-se necessário que o país tenha uma política forte e autêntica, para a construção de uma educação de qualidade, com ações efetivas, concretas e dialogadas com a sociedade. Acreditamos que o PIBID tem representado um espaço privilegiado para a ampliação do diálogo entre a universidade e a escola de Educação Básica, construindo um clima de respeito, trocas, diálogos e criatividade.

O projeto Pibid Pedagogia/Gestão almejou a produção de conhecimentos e práticas pedagógicas sobre a gestão, com o intuito de incentivar a docência e a gestão em uma perspectiva democrática. No campo da formação, temas como a participação, o coletivo, a elaboração do Projeto Político Pedagógico da escola, formas de análise da realidade, políticas de avaliação da aprendizagem e externa colaboram para a ampliação de uma qualidade fundamentada na empiria da escola, em diálogo permanente com a análise teórica. Nessa perspectiva, a formação foi uma linha de ação desenvolvida pelos/as bolsistas com base nos estudos bibliográficos, num processo de análise e síntese acerca de cada um dos temas. 
Acreditamos que a práxis que o Pibid possibilita aos/às licenciandos/as é essencial para o entendimento da realidade complexa da escola. A oportunidade de trabalhar diretamente no ambiente escolar é primordial para a formação e, por consequência, no aprimoramento dos cursos de licenciaturas, que contarão com estudantes que provocam no âmbito acadêmico as problematizações que vivenciam no contexto da Educação Básica.

\section{Considerações finais}

Da nossa análise, concluímos que o programa gera impactos expressivos tanto na formação inicial dos/as bolsistas/estudantes, quanto na formação continuada dos/as professores/as e gestores/as da Educação Básica envolvidos direta ou indiretamente no Pibid.

Nessa conjuntura, o Pibid tem contribuído para que os/as licenciandos/as ressignifiquem a identidade docente por meio da reflexão teórica sólida sobre a realidade em que se inserem. Esse processo, em nossa visão, extrapola a formação dos/as pibidianos/as e colabora com os demais licenciandos/as das turmas das quais os/as bolsistas participam. Assim, a formação possibilitada pelo Pibid contribui para que haja intensa troca de conhecimentos entre os/as pibidianos/as, entre eles/as e os/as demais licenciandos/as que não fazem parte diretamente do programa e os/as professores/as do curso de formação. Defendemos que o Pibid deve ser uma prática desenvolvida com todos/as os/as licenciandos/as, como política nacional de formação.

Além do mais, evidenciamos que a problemática da formação docente passa atualmente não apenas por questões de ordem estrutural de sua formação e atuação mas também por uma política nefasta de difamação dos professores, percebida como estratégia de desmonte de importantes políticas educacionais que outrora foram conquistadas (como o PIBID, o ensino público e a expansão das universidades e institutos federais) com vistas à privatização geral do ensino.

Em tempos sombrios, como os do nosso contexto político-social-educacional, faz-se urgentíssima a união de todos e todas, "que ninguém 
solte a mão de ninguém”, num movimento contínuo e intenso de resistência, a fim de garantir que os direitos conquistados não sejam perdidos, para, a partir daí, ir além, rumo a novas conquistas. Numa visão freireana, esperançar com ação é práxis transformadora.

\section{Referências}

ARAUJO, Adilson Cesar de. A gestão democrática e os canais de participação dos estudantes. Revista Retratos da Escola, Brasília, v. 3, n. 4, p. 253-266, jan./jun. 2009.

BARBOSA, L. F. Jovens e movimentos sociais no Brasil: interrogando significados das manifestações de junho de 2013. In: ANPED SUL, 10. 2014, Florianópolis. Anais... Florianópolis, ANPED SUL.

BORGES, M.B.; RIBEIRO, B. L.O.; RICHTER, L.M. Desafios da educação integral no tempo presente. In: Rev. Ed. Popular, Uberlândia, v. 17, n.2, p. 131-143, maio/ago. 2018. Disponível em: <file:///C:/Users/marce/Downloads/41393-Texto\%20do\%20artigo-186617-1-10-20181003.pdf.> Acesso em: 20 mar. 2019.

BRASIL. Constituiçãa Federal. Constituição da República Federativa do Brasil. Brasília: Senado Federal, 1988.

BRASIL. Lei no 9.394, de 20 de dezembro de 1996. Estabelece as diretrizes e bases da educação nacional. Diário Oficial [da República Federativa do Brasil], Brasília, DF, 1996.

BRASIL. Lei n. 11.738 de 16 de julho de 2008. Regulamenta a alínea "e" do inciso III do caput do art. 60 do Ato das Disposições Constitucionais Transitórias, para instituir o piso salarial profissional nacional para os profissionais do magistério público da educação básica. Diário Oficial [da República Federativa do Brasil], Brasília, 16 de jul. 2008.

BRASIL. Edital Capes no 06/2018. Programa de Residência Pedagógica - Chamada Pública para apresentação de propostas no âmbito do Programa de Residência Pedagógica. Brasília, 2018.

BRASIL. Edital Capes no 07/2018. Programa Institucional de Bolsa de Iniciação à Docência - Pibid. Chamada Pública para Apresentação de Propostas no âmbito Pibid. Brasília, 2018.

DOURADO, L. F. A escolha de dirigentes escolares: políticas e gestão da educação no Brasil. In: FERREIRA, N. S. C. (Org.) Gestão Democrática da educação: atuais tendências, novos desafios. São Paulo: Cortez, 1998.

FREIRE, Paulo. Pedagogia da Autonomia. Saberes necessários à prática educativa. São Paulo: Paz e Terra, 1996. 
FERNÁNDEZ CRUZ, Manuel. Desarrollo profesional docente. España: Grupo Editorial Universitario, 2006.

GARCÍA, Carlos Marcelo. Estrutura conceitual da formação de professores. In: GARCÍA, Carlos Marcelo (Org.). Formação de professores para uma mudança educativa. Lisboa: Porto, 1999.

NÓVOA, A. Relação escola-sociedade: novas respostas para um velho problema. In: SERBINO, R. V. et al. (Orgs.). Formação de professores. São Paulo: UNESP, 1998, p.19-40.

UFU. Pibid. Disponível em: <http://www.prograd.ufu.br/servicos/pibid>

VÁZQUEZ, Adolfo Sánchez. Filosofia da Práxis. Trad. Luiz Fernando Cardoso. Rio de Janeiro: Paz e Terra, 1977. 


\section{NATURALIZACCÃO DO ESTÁGIO E INVISIBILIDADE DO TRABALHO (DO ESTÁGIO CURRICULAR OBRIGATÓRIO): UMA TESE EM CONSTRUÇÃO}

Valdeniza Maria Lopes da Barra

\section{Introdução}

A prática de ensino constitui-se como dimensão prevista na formação de professores desde que este profissional é alçado nas narrativas histórica e política como o sujeito a quem se delega o trabalho ou a profissão de ensinar. No caso afeto à escolarização inicial, localizam-se os fundamentos dessa formação na preocupação das primeiras escolas normais e respectivas escolas-modelo, cujo fim seria a prática de ensino dos futuros professores. Nos anos 1930, quando o curso de Pedagogia chega ao Ensino Superior, a prática de ensino terá como alternativa os Colégios de Aplicação, criados no início dos anos 1940. O dispositivo que recomenda a realização da prática de ensino no formato de estágio e, portanto, na escola "real" (campo de atuação profissional do futuro professor), é a Resolução n. 9 de 1969. A implementação do estágio na escola "real" requer o envolvimento de diferentes pessoas, entre as quais está o professor da universidade, o professor da escola e o estagiário. Neste texto se busca, especialmente, pensar o trabalho do professor da escola com estágio.

Para tanto, se vale de alguns resultados obtidos pela pesquisa Recortes da relação entre formação e atuação docente no estágio ${ }^{1}$, que é composta de quatro eixos temáticos, sendo: 1) Política de formação de professores/estágio da Universidade Federal de Goiás (instituição formadora) e políticas de formação de professores/estágio das instituições concedentes de estágio (rede estadual/Goiás e rede municipal/Goiânia); 2) O estágio curricular

\footnotetext{
${ }^{1}$ Vinculada ao Núcleo de Formação de Professores (Nufop), sediado na Faculdade de Educação da UFG.
} 
obrigatório no curso de Pedagogia da Faculdade de Educação/UFG; 3) Sujeitos do estágio (professor orientador, professor supervisor, estagiário); 4) Docência stricto sensu/relação entre a formação e a atuação. A referida pesquisa parte do entendimento de que o estágio desenvolvido no curso de Pedagogia se constitui como espaço privilegiado de tensão e diálogo nas relações entre a formação e a atuação, entre a universidade e a escola básica, entre a teoria e a prática.

\section{Diálogos com estudiosos do tema}

Maria do Socorro L. Lima (2012, p. 137-151) identifica seis perspectivas de tratamento do estágio, em pesquisas apresentadas nos Anais do Endipe (2008 e 2010): 1) o estágio como prática pedagógica inserida na prática social; 2) o estágio como teoria que ressignifica a prática; 3) o estágio como objeto de investigação e reflexão e de construção e articulação de saberes e conhecimentos; 4) o estágio como espaço/tempo de aprendizagem; 5) o estágio como oportunidade de experiências pedagógicas; 6) o estágio como possibilidade de ensino/aprendizagem da profissão, tutoria e monitoria. Para a autora, as discussões sobre o estágio têm constituído um espaço, dentro do Endipe, que lhe permite, entre outros alcances, "a valorização da prática e a respectiva reflexão sobre ela no contexto escolar, das condições objetivas que estas práticas se realizam na vida dos alunos e dos professores.” (Lima, 2012, p. 151).

O ponto de vista observado por Lima (2012) parece confluir com o entendimento do estágio como ponto de cruzamento, interseção ou articulação entre teoria e prática vista na especificidade pedagógica do trabalho docente, que é disposta pela relação entre a formação inicial do estudante de pedagogia e a formação continuada do professor da escola (campo de estágio). Essa forma de enxergar o estágio é uma das hipóteses desta proposta de pesquisa que, em alguma medida, se identifica com a postura que reconhece "a importância da necessidade de rever a questão do estágio, da relação universidade e escola, da relação teoria-prática no processo formativo de professores" (Ghedin, Almeida, Leite, 2008, p. 18). 
Em 1990, Stela Piconez apresentava a primeira edição do livro $A$ prática de ensino e o estágio supervisionado. Esse livro vinha na esteira da revisão da Didática operada desde 1982, quando a reflexão sobre a relação teoria e prática aparece vigorosa, impondo à prática de ensino/estágio a ação de pensar seus limites e possibilidades (Piconez, 2005, p. 9-13). Ao menos duas questões basilares devem ser registradas aqui, a partir da leitura desse livro. A primeira questão refere-se ao sentido do estágio no curso de licenciatura e, a segunda, ao modo como o estágio implica a relação entre a universidade e a escola básica. Sobre a primeira questão, o sentido do estágio no curso de licenciatura:

O espaço do estágio é o eixo que poderia articular a integração teoria-prática entre os conceitos da Parte Diversificada e do Núcleo Comum do curso de formação de professores e o conhecimento da realidade da sala de aula na escola pública (Piconez, 2005, p. 22);

A Prática de Ensino/Estágio Supervisionado precisa ampliar sua caracterização política, epistemológica e profissional, uma vez que, sendo uma atividade teórico-prática, envolve a totalidade das ações do currículo do curso. (Piconez, 2005, p. 31);

É possível pensar em estágio sem pensar num projeto coletivo maior para a formação do educador? Melhor explicando: pensar o Estágio, desvinculado de um pensar a Didática, a Prática de Ensino, a Filosofia, a Sociologia e as outras disciplinas que compõem os cursos de formação do educador é admitir que ou o Estágio seja o "salvador do curso", ou que ele seja tão pouco importante, que pode ter tratamento diferenciado... (Fazenda 2005, p. 56);

Sobre a segunda, o modo como o estágio implica a relação entre a universidade e a escola básica:

A elaboração do projeto de estágio no interior de seu plano de curso precisa contar com todos os elementos envolvidos, inclusive com os professores do campo de estágio (Piconez, 2005, p. 31).

[...] seja elaborado um projeto - de preferência em conjunto, inclusive com o professor da escola de estágio. (Kenski apud Piconez, 2005, p. 40). 
Outra experiência importante encontra-se relatada no livro $O$ estágio na formação compartilhada do professor: retratos de uma experiência. Nesse trabalho, pretende-se "articular a formação inicial com formação contínua do professor em serviço", o que teria sido possível com a interação entre "licenciandos com os professores de prática de ensino, ao discutirem as atividades a serem desenvolvidas nas escolas”. (Moura, 1999, p. 7). Também é objetivo dessa obra "aprofundar a integração Universidade-escola e dinamizar esta relação por meio de ações que favoreçam a autonomia de novas práticas dentro da escola e que, ao mesmo tempo, alimentem a universidade" (Moura et al. 1999, p.7).

O conjunto das produções bibliográficas mencionadas revela aspectos estruturantes do estágio e indica que eles podem potencializar a discussão sobre a formação de professores. Entretanto, estudo publicado em 2017 trabalha com a hipótese de que haveria uma espécie de naturalização ou invisibilização do estágio (Barra, 2017). Essa naturalização ou invisibilidade pode ser flagrada desde o momento em que a prática de ensino passou a ser desenvolvida no formato de estágio, o que ocorreu com o texto da resolução n.9 de 1969. De lá para cá, verifica-se que poucos documentos se propõem a orientar, com clareza, a relação entre a instituição formadora (universidade) e a instituição concedente (escola campo de estágio). Dentre as investidas existentes nas duas últimas décadas, merece estaque o texto da LDB n. 9394/96, no qual se pode ler: "Os sistemas de ensino estabelecerão as normas de realização de estágio em sua jurisdição, observada a lei federal sobre a matéria. (Redação também vista na Lei no 11.788, de 2008)" (Título VIII. Das disposições gerais, Art. 82). O fragmento destacado demonstra que o estágio marca um tipo de relação entre a universidade e a escola (redes de ensino), e que compete à instituição concedente, via "sistemas de ensino", a elaboração de "normas de realização de estágio em sua jurisdição". ${ }^{2}$ O texto da LDB

\footnotetext{
${ }^{2}$ Poderia se perguntar para os sistemas de ensino (secretarias) sobre as mencionadas normas. Essa pergunta foi feita em 2015 aos sistemas de ensino (estadual Goiás e municipal goiano) no âmbito do I Simpósio do Núcleo de Formação de Professores NUFOP (FE/UFG). Em momento oportuno, neste texto, será tratada a questão.
} 
também menciona o reconhecimento de que há a ampliação do conceito de docência, relacionado ao repertório que compõe o trabalho docente:

[...] participar da elaboração da proposta pedagógica; elaborar e cumprir plano de trabalho; zelar pela aprendizagem dos alunos; propor estratégias de recuperação aos alunos de menor rendimento; participar integralmente dos períodos dedicados ao planejamento, à avaliação e ao desenvolvimento profissional; colaborar com as atividades de articulação da escola com as famílias e a comunidade (Brasil, 1996, art. 13).

O cruzamento desses dois fragmentos da LDB n. 9394/96 ajuda a ver o invisível. Note-se que, ao mesmo tempo que a lei instrui os sistemas de ensino para que elaborem as respectivas normas de realização do estágio, a mesma lei não relaciona na lista de incumbências do professor o trabalho com a supervisão do estágio. Ou seja, a LDB n. 9394/96 silencia sobre o trabalho docente do professor da escola básica com o estágio, ao mesmo tempo que determina aos sistemas de ensino o que devem fazer em relação à recepção do estágio nas escolas.

Essa contradição, dentre outras apontadas por Barra (2017), marca o interesse desse trabalho que aventa para a hipótese de que a naturalização ou invisibilidade do estágio e dos engendramentos por ele implicados constituem flancos na organização política e cotidiana dos estágios e, por conseguinte, das relações entre a universidade e a escola básica. Esse quadro abre caminho para medidas "intervenientes" e pretensamente suplantadoras do estágio, como postulam, respectivamente, o Pibid (Programa de Bolsa de Iniciação à Docência) e a Residência Pedagógica, principais programas na pauta recente da Política Nacional de Formação de Professores do país.

Em convergência com a autora Kenski (1991), para quem o estágio deve pactuar a relação entre a instituição formadora e a concedente, as DCNs Pedagogia (2006), seguidas pela Lei Geral de Estágios, ponderam:

O estágio, como ato educativo escolar supervisionado, deverá ter acompanhamento efetivo pelo professor orientador da instituição de ensino e por supervisor da parte concedente, comprovado por vistos nos rela- 
tórios referidos no inciso IV do caput do art. $7^{\circ}$ desta Lei e por menção de aprovação final. (DCN Pedagogia, cap. I, § 1'; Lei n. 11.788, 25/09/2008, cap. I, § $1^{\mathrm{o}}$ ). (grifos da autora).

Em paralelo a uma legislação que, a partir da LDB n. 9394/96, procura marcar a relação da universidade com a escola básica, por meio do estágio, tem-se a literatura especializada e autoridades do assunto, a se pronunciar sobre o estágio como campo que, minimamente, precisa ser olhado.

[...] não há especificação clara sobre como são realizados, supervisionados e acompanhados. Sobre a validade ou validação desses estágios também não se encontrou nenhuma referência. Não estão claros os objetivos, as exigências, formas de validação e documentação, acompanhamento, convênios com escolas das redes etc. Essa ausência nos projetos e ementas pode sinalizar que, ou são considerados totalmente à parte do currículo, o que é um problema, na medida em que devem integrar-se com as disciplinas formativas e com aspectos da educação e da docência, ou, sua realização é considerada como aspecto meramente formal. (Gatti et al., 2010, p.106).

Há a necessidade de rever o estatuto do professor do campo de estágio no estágio (Pimenta, 2010, p. 22).

Os estágios são mal acompanhados pelos professores dos cursos superiores e nem sempre são realizados em escolas com bom desempenho pedagógico (Valle, ANFOP, Folha de São Paulo, 4 ago. 2013).

E tem-se ainda, no marco das políticas educacionais, o Plano Nacional de Educação, que prevê como meta 12 da estratégia 8: "ampliar a oferta de estágio como parte da formação na educação superior”. Estratégia 8 da meta 12, Plano Nacional de Educação 2014 (Lei n 13.005).

Nesse cenário, no qual o estágio se desponta como espaço da formação docente que é a um só tempo forte e frágil, surgem o Pibid (2010) e, mais recentemente, a Residência Pedagógica. A seguir, um cronograma das investidas mais recentes que pretendem ser estratégias "intervenientes" (Pibid) ou suplantadoras do estágio (Residência Pedagógica). 
Quadro 1 - Pibid e Residência Pedagógica

\begin{tabular}{|c|c|}
\hline Programas & Aspectos gerais de cada programa \\
\hline $\begin{array}{l}\text { Decreto n. } \\
\text { 7219/2010 } \\
\text { PIBID (Programa } \\
\text { de Bolsa de } \\
\text { Iniciação à } \\
\text { Docência) }\end{array}$ & $\begin{array}{l}\text { Compõe a Política Nacional de Formação de } \\
\text { Professores do Ministério da Educação (MEC). São } \\
\text { características: } \\
\text { - Promove a parceria universidade-escola nos } \\
\text { processos de formação do futuro professor; Disponível } \\
\text { em: http://capes.gov.br/images/stories/download/ } \\
\text { bolsas/24112014-pibid-arquivoAnexado.pdf, acesso } \\
\text { em } 20 \text { de outubro e 2017; } \\
\text { - Visa proporcionar aos discentes na primeira metade } \\
\text { do curso de licenciatura uma aproximação prática com } \\
\text { o cotidiano das escolas públicas (grifo meu); } \\
\text { - Prevê que os discentes serão acompanhados por } \\
\text { um professor da escola e por um docente de uma das } \\
\text { instituições de educação superior participantes do } \\
\text { programa; } \\
\text { - Concede bolsas a alunos de licenciatura participantes } \\
\text { de projetos de iniciação à docência; é o único aspecto que } \\
\text { distingue do estágio. Disponível: https://capes.gov.br/ } \\
\text { educacao-basica/capespibid, acesso em } 02 \text { de setembro } \\
\text { de } 2017 \text {. }\end{array}$ \\
\hline $\begin{array}{l}\text { Residência } \\
\text { Pedagógica }\end{array}$ & $\begin{array}{l}2012 \text { - Blairo Maggi (PR MT) apresenta projeto que } \\
\text { determina a obrigatoriedade da residência pedagógica } \\
\text { para obtenção do título de professor. } \\
\text { 04/08/ } 2013 \text { - Folha de São Paulo. Em matéria } \\
\text { publicada por esse jornal, Luiz Carlos de Freitas, então } \\
\text { diretor da Faculdade de Educação da Unicamp, defende } \\
\text { a residência pedagógica no modelo finlandês, o que } \\
\text { significa, dentre outras, que a residência deve acontecer } \\
\text { "após a conclusão dos créditos". } \\
\text { 18/10/2017 - Governo federal lança Política Nacional } \\
\text { de formação de Professores tendo a BNCC como } \\
\text { norteadora do currículo da formação de professores e } \\
\text { o Programa Residência Pedagógica como linha de ação } \\
\text { na formação inicial. }\end{array}$ \\
\hline
\end{tabular}

Fontes: Fundação Carlos Chagas, 2014; Brasil, 2013; Folha de São Paulo, 2013.

O caminho aqui percorrido pretendeu demonstrar que a prática de ensino com recomendação de acontecer na "escola real" é inerente ao estágio (Resolução n. 9 de 1969), isto é, é o estágio que inscreve a relação 
entre a universidade e a escola "real". $\mathrm{Na}$ atualidade, entretanto, assiste-se à transferência dessa prerrogativa do estágio para outras esferas ou programas (Pibid, Residência Pedagógica), o que se interpreta como a principal resultante de uma sucessão errática de intervenções nos processos de formação de professores, em cuja base está a naturalização ou invisibilização do estágio curricular obrigatório.

\section{Caminhos da pesquisa}

Combinando estudo bibliográfico e documental, a pesquisa também conta com instrumentos de pesquisa elaborados no formato de questionários com questões mistas (abertas e fechadas), endereçados aos professores supervisores (escola), aos estagiários de Pedagogia e aos coordenadores de estágio nas licenciaturas da Universidade Federal de Goiás.

Dentre os documentos de estudo, estão aqueles que normatizam a formação de professores e os estágios no âmbito federal e institucional (UFG), os documentos que norteiam o estágio nas instituições concedentes, relatórios de estágio e resumos acadêmicos do Seminário de Estágio de Pedagogia da FE (UFG), anos 2010 a 2015, Projeto Político Pedagógico (PPP) das escolas abrangidas pela pesquisa. Esses últimos apresentam-se no quadro a seguir.

Quadro 2 - Projetos Político-Pedagógicos das instituições campo de pesquisa do curso de Pedagogia (FE/UFG - 2010 a 2015)

\begin{tabular}{|l|c|l|c|}
\hline \multicolumn{1}{|c|}{ Redes } & Quantidade & \multicolumn{1}{|c|}{ Modalidades/Etapas } & Período \\
\hline Federal & 1 & $\begin{array}{l}\text { Educação Infantil e Anos Iniciais do EF } \\
\text { (6 a 10) }\end{array}$ & 2013 \\
\hline Municipal & 8 & $\begin{array}{l}\text { Educação Infantil, Anos Iniciais do EF } \\
\text { (6 a 10) e Anos Iniciais do EF (EJA) }\end{array}$ & $\begin{array}{c}2009 \text { a } \\
2015\end{array}$ \\
\hline Estadual & 1 & Anos Iniciais do EF (6 a 10) & 2015 \\
\hline
\end{tabular}

A pesquisa também conta com o estudo do conjunto dos resumos acadêmicos de estudantes de Pedagogia da Faculdade de Educação da UFG, inscritos nos anos 2010 a 2015. 
Quadro 3 - Resumos Acadêmicos

\begin{tabular}{|c|c|c|c|c|c|}
\hline \multirow{2}{*}{ Ano } & \multirow{2}{*}{$\begin{array}{c}\text { Trabalhos } \\
\text { inscritos }\end{array}$} & \multicolumn{4}{|c|}{ Etapas/modalidades da escola básica } \\
\cline { 3 - 6 } & & EI & $\begin{array}{c}\text { Anos } \\
\text { iniciais EF }\end{array}$ & $\begin{array}{c}\text { Anos } \\
\text { Iniciais EF/ } \\
\text { EJA }\end{array}$ & $\begin{array}{c}\text { Não há } \\
\text { menção }\end{array}$ \\
\hline 2010 & - & - & - & - & - \\
\hline 2011 & 27 & 7 & 15 & 2 & 3 \\
\hline 2012 & 42 & 17 & 19 & 7 & 0 \\
\hline 2013 & 63 & 33 & 21 & 8 & 1 \\
\hline 2014 & 99 & 56 & 26 & 15 & 2 (a serem \\
\hline & 231 & 113 & 81 & 32 & 6 \\
\hline TOTAL & $100 \%$ & $49 \%$ & $35 \%$ & $13,9 \%$ & $2,5 \%$ \\
\hline
\end{tabular}

Obs.1: Em 2010 foi realizada a primeira edição do Seminário de Estágio de Pedagogia da FE. Os resumos inscritos nesta edição não estavam publicados no site, por ocasião do estudo realizado.

Obs.2: No ano 2015 não houve a realização do evento dada a realização de greve no período.

Dentre os sujeitos abrangidos pela pesquisa - respondentes de questionários, estão:

Quadro 4-Sujeitos da pesquisa

\begin{tabular}{|l|c|l|}
\hline Sujeitos & N. & $\begin{array}{l}\text { Áreas/modalidades/redes } \\
\text { abrangidas }\end{array}$ \\
\hline Estagiários & 28 & Curso de Pedagogia \\
\hline $\begin{array}{l}\text { Coordenadores de estágio em } \\
\text { Licenciaturas da UFG (Goiânia) }\end{array}$ & 8 & $\begin{array}{l}\text { Letras, Biologia, Psicologia, } \\
\text { Geografia, Educação Física, Artes } \\
\text { Cênicas, Filosofia, Pedagogia. }\end{array}$ \\
\hline $\begin{array}{l}\text { Professores supervisores de estágio } \\
\text { (campo) do curso Pedagogia }\end{array}$ & 61 & $\begin{array}{l}\text { Modalidades: Educação Infantil, } \\
\text { Anos Iniciais (6 a 10) e Anos Iniciais } \\
\text { (EJA) } \\
\text { Redes: federal, municipal, estadual }\end{array}$ \\
\hline Total & 97 & \\
\hline
\end{tabular}


O conjunto da documentação arrolada é organizado pelos quatro eixos temáticos, quais sejam: 1) Política de estágio; 2) Projeto de Estágio de Pedagogia da FE/UFG; 3) Sujeitos do estágio; 4) Docência Stricto Sensu. ${ }^{3}$

\section{Alguns aspectos (temas) evidenciados na pesquisa}

Tema 1: Relação entre a instituição formadora (professor orientador) e instituição concedente (professor supervisor)

1.a) Na perspectiva dos estudantes de Pedagogia (estagiários):

Dos vinte e oito alunos que responderam ao questionário, 10 (35,7\%) avaliaram que o acompanhamento do professor da escola é "ótimo", seguido de 13 (46,4\%) “bom” e 3 (10,7\%) "regular". Dentre os 10 estagiários (35,7\%) que avaliaram o acompanhamento do professor da escola como "ótimo", 7 (25\%) também afirmaram que havia parceria entre "o professor orientador e o professor supervisor (escola-campo)". O universo dos 35,7\% abrange experiências de estágio nas redes estadual, municipal e federal. Três estagiários $(10,7 \%)$ relacionaram, entre as dificuldades do estágio, a relação com o professor supervisor da escola: "dificuldade na relação professor-regente", "convivência com o professor supervisor do campo de estágio", "o professor da escola que nos recebeu não estava satisfeito com a nossa presença”.

1.b) Na perspectiva dos professores supervisores do estágio (escola):

Nas três redes de ensino, 54 professores supervisores responderam ao questionário, sendo que, em alguns casos, assinalaram mais que uma alternativa das questões de múltipla escolha. Exemplo disto aconteceu com a questão que interrogava sobre a "recepção dos estagiários na escola", na qual se teve o total de 67 respostas assinaladas. Deste total (respostas assinaladas), 20 (29,8\%) entendem que o professor deve ter a liberdade de aceitar ou não a presença de estagiários, enquanto 40 (59,6\%) avaliam que "todos são responsáveis pela formação dos futuros professores" e, portanto, "devemos recebê-los"; 4 (5,9\%) entendem que "não importa a opinião pessoal do

\footnotetext{
${ }^{3}$ As atividades de pesquisa referentes ao eixo Docência Stricto Sensu foram canceladas em função da dificuldade de obter alunos do quarto ano do curso de pedagogia na FE (UFG) em 2017 para a realização de grupos focais..
} 
professor, o estagiário tem o direito de participar da rotina da escola", e 3 $(4,47 \%)$ assinalaram alternativa "não sei emitir opinião sobre este assunto".

Interrogados sobre o papel do professor supervisor em relação ao estágio (n.17), 52 (77,6\%) das 67 respostas afirmaram "receber os estagiários, compartilhar o trabalho pedagógico da turma/escola, planos, atividades", $7(10,4 \%)$ das respostas revelam que os professores entendem que devem receber estagiários e conversar com eles durante o recreio, e 4,4\% afirmam que é difícil receber o estágio, já que as condições de trabalho não ajudam.

Do total de 54 professores que responderam à questão sobre "o maior entrave para a relação entre o estagiário e o professor da escola”, 26 (\%) avaliaram que é "o tempo exíguo do professor da escola", 11 (\%) disseram que é o "pouco esforço e disponibilidade do estagiário", enquanto o restante atribui ao "imponderável” ou outros.

À questão que perguntava sobre a presença do professor orientador (universidade) no campo de estágio, obteve-se 58 respostas $(95,98 \%)$, do total de 61, que afirmavam que a presença do professor da universidade facilita a comunicação entre a escola e a universidade, assim como representa "intermediação importante junto ao estagiário", enquanto 2 (3,4\%) respostas indicaram ser "impraticável receber o estagiário sem o professor da universidade, já que teríamos mais encargos além dos existentes”, e 1 $(1,7 \%)$ assinalou a alternativa que entende que "o estágio pode acontecer com ou sem o professor da universidade" na escola.

Comparando as visões de estagiário e professor supervisor (escola) acerca da qualidade dessa relação:

Quadro 5 - Visões da escola

\begin{tabular}{|l|l|}
\hline Professor & Ótima (54,09\%), boa (40,98\%), regular (4,91\%). \\
\hline Estagiário de Pedagogia & Ótima (35,7\%), boa (46,4\%), regular $(10,7 \%)$. \\
\hline
\end{tabular}

Obs.: A alternativa "ruim" não foi assinalada por nenhum dos respondentes.

Os dados obtidos pela pesquisa revelam que os estagiários avaliam de forma positiva a relação com o professor da escola, apesar de demandarem pela qualificação dessa instituição. A compreensão dessa questão é ajudada 
com dados obtidos no estudo dos resumos acadêmicos dos estagiários ${ }^{4} \mathrm{da}$ rede federal, onde $100 \%$ daqueles que mencionam essa questão reconhecem a qualidade do acompanhamento recebido do professor do campo. Nas demais redes (estadual e municipal), o diálogo existe, mas é sensivelmente dificultado pelo cotidiano, historicamente construído, que o inscreve (estágio) de forma naturalizada, no repertório geral do trabalho docente. As respostas dos professores, quando mais da metade avaliam como "ótima" a relação com os estagiários, informam que estes fazem o que é possível, no limite dado pelas contingências. Tais respostas também apontam para algumas pautas. A necessidade de enxergar o estágio como trabalho, com rebatimento sobre a identidade da escola, implica um redimensionamento em cadeia, a envolver: instituição formadora, instituições concedentes (secretarias e escolas), certificação acadêmica, política de valorização e carreira docente, organização do trabalho docente na escola, enfim, o estágio como campo interseccional de complexidade para a formação inicial e continuada de professores. ${ }^{5}$

Tema 2: Tempo de supervisão de estágio dos professores respondentes da pesquisa $\mathrm{X}$ o estágio nos PPP das escolas abrangidas pela pesquisa

Neste tópico será contraposto o tempo médio de supervisão de estágio dos supervisores e o modo como o estágio aparece no Projeto Político Pedagógico das escolas afins.

Quadro 6-Tempo de supervisão de estágio

\begin{tabular}{|l|l|}
\hline Jurisdição & $\begin{array}{l}\text { Tempo que os professores recebem estagiários (supervisores de } \\
\text { estágio) }\end{array}$ \\
\hline Municipal & $\begin{array}{l}2,27 \% \text { (1) há mais de } 20 \text { anos; } 2,27 \% \text { (1) de } 16 \text { a } 20 \text { anos; } 25 \% \\
(11) \text { de } 6 \text { a } 10 \text { anos; } 56,8 \% \text { (25) de } 1 \text { a } 5 \text { anos; o restante, há } \\
\text { menos de } 1 \text { ano. }\end{array}$ \\
\hline
\end{tabular}

\footnotetext{
${ }^{4}$ Evento anual de socialização das experiências de estágio dos estudantes do curso de Pedagogia da FE/UFG, desde 2010. Os resumos dos estagiários também constituem documentos de estudo na pesquisa em andamento.

${ }^{5}$ Tais questões constituem alvo de aprofundamento na pesquisa em andamento.
} 


\begin{tabular}{|c|l|}
\hline Estadual & $\begin{array}{l}\text { 50\% dos respondentes informaram 1 a } 5 \text { anos, enquanto a outra } \\
\text { metade declarou atuar como supervisor de estágio há mais de } 20 \\
\text { anos. }\end{array}$ \\
\hline Federal & $\begin{array}{l}20 \% \text { afirmaram receber estagiários de } 16 \text { e } 20 \text { anos, } 30 \% \text { de } 1 \text { a } \\
10 \text { anos e o restante há menos de um ano. }\end{array}$ \\
\hline
\end{tabular}

Rede federal: $\mathrm{O}$ Centro de Ensino e Pesquisa Aplicada à Educação (CEPAE) surgiu como Colégio de Aplicação, criado pelo Decreto-lei n. ${ }^{\circ}$ 9.053, de 12 de março de 1.966 , e suas atividades tiveram início em março de 1968, no prédio da Faculdade de Educação/UFG, constituindo-se como órgão suplementar desta, tendo como objetivos:

[...] constituir-se em laboratório experimental de técnicas e processos didáticos, visando ao aprimoramento da metodologia de ensino; constituir-se em escola experimental para novos cursos previstos na legislação vigente e servir como campo de estágio supervisionado para a Licenciatura e para as habilitações do curso de Pedagogia (Silva, $2017 \mathrm{~s} / \mathrm{p}$ ). ${ }^{6}$

O PPP do CEPAE (2013) indica que, desde 2006, a instituição é constituída de infraestrutura composta de 58 salas, sendo uma delas denominada "sala de estágio". A organização administrativa do CEPAE possui órgãos diretivos aos quais se subordinam comissões permanentes, dentre as quais está a comissão de estágio, cujo papel é articular os projetos de estágio (art.19, regimento). O CEPAE possui três secretarias (executiva, administrativa, de pesquisa e pós-graduação). A primeira é responsável, dentre outras, pela documentação relacionada ao estágio. Dentre as atividades do quadro docente do CEPAE, está a atividade de "supervisão a alunos de Graduação e Pós-Graduação”. Um tópico específico do referido PPP é denominado Estágio e, sobre essa matéria, ocupa 20 linhas de texto, quase uma página.

\footnotetext{
${ }^{6} \mathrm{Em} 1980$, uma greve obteve a reclassificação dos professores de $1^{\circ}$ e $2^{\circ}$ graus para a carreira de magistério superior, condição única de CEPAE, em todo o país. Uma sucessão de mudanças conduziu o Colégio de aplicação à independência da Faculdade de Educação, passando a funcionar em prédio próprio, a partir de 1994.
} 
Rede municipal: Trata-se da rede com maior concessão de campos de estágio para a licenciatura em Pedagogia da UFG. Selecionou-se aqui, de forma aleatória, os PPP de três escolas, denominadas A, B e C. No PPP $(2013,2014)$ da escola A não há nenhum tipo de menção ao estágio. No PPP (2011) da escola B há um histórico que informa que a instituição, fundada em 1953, nasceu como parte do Instituto de Educação de Goiás (IEG) "com o objetivo de ser escola-campo de estágio e formação para o curso de magistério do IEG". O mesmo documento informa a existência de "parceria" com a UFG, por meio do "estágio supervisionado do curso de Pedagogia”. O PPP da escola $\mathrm{C}$ faz um único tipo de menção ao estágio: "Planejamento poderá acontecer em horário de aula, desde que o coletivo se organize de forma que os alunos não sejam dispensados (estágios, palestras, organização do próprio coletivo)”.

Rede estadual: Nenhum tipo de menção ao estágio.

O PPP é o documento da escola, tornado uma exigência pela LDB n. 9394/96. Trata-se de um documento que emerge no contexto da afirmação democrática, da gestão colegiada e autônoma da escola, sendo considerado espaço de relevo no qual a escola demonstra a "capacidade de delinear sua própria identidade". (Veiga, 1995, p.14). Esse entendimento ajuda a compreender o quadro composto pela pesquisa. Dentre os professores supervisores de estágio, 30\% (rede municipal), 50\% (rede estadual) e 20\% (rede federal) recebem estagiários (futuros professores), entre 16 e 20 anos ou mais, isto é, tempo médio de existência da LDB n. 9394/96. O estágio comparece nos textos dos PPP das instituições vocacionadas historicamente para o papel de corresponsáveis pela formação de futuros professores, casos do $\mathrm{CEPAE}^{7}$ e da escola $\mathrm{B}$, instituição da rede municipal de Goiânia, cujo nascimento remonta ao $\mathrm{IEG}^{8}$. Portanto, ambas têm a fundação voltada para a formação de professores. Vale o registro de que, numa das escolas da rede municipal, a referência ao estágio aparece como o momento no qual os professores podem se ocupar de ações afetas ao

\footnotetext{
${ }^{7}$ Colégio de Aplicação da Universidade Federal de Goiás, hoje Centro de Ensino Pesquisa Aplicada à Educação (CEPAE).

${ }^{8}$ IEG - Instituto de Educação de Goiás, fundado nos anos 1950.
} 
planejamento, já que os alunos não serão “dispensados”, isto é, poderão ficar sob os cuidados dos estagiários.

Há diferenças importantes no conjunto de referências ao estágio observadas nas redes federal e municipal das instituições com história associada à formação de professores, quais sejam, a infraestrutura, a identidade do professor ao trabalho de supervisionar o estágio da rede federal, por exemplo. $\mathrm{Na}$ rede municipal (escolas $\mathrm{A}, \mathrm{B}, \mathrm{C}$ ) essas questões não têm voz. ${ }^{9}$ Tais diferenças ajudam a entender como a "escola real" naturalizou a relação com o trabalho de "supervisão" do estágio, por isso o silêncio ou as poucas palavras a respeito do estágio no PPP, indiciando que o trabalho com estágio existe de forma "natural", não é ação da escola que constitua sua identidade. Os diferentes manuais disponíveis para a elaboração de um PPP também silenciam a esse respeito.

\section{Considerações finais}

O estágio curricularobrigatório ocupa umlugar importante na formação de professores e, apesar de ser uma prática com quase cinco décadas de existência, requer reflexão sobre os processos que normatizam o seu modus operandi. Os engendramentos associados ao estágio aquilatam a sua complexidade, inscrita na relação entre universidade e escola, na formação inicial e continuada, na articulação entre teoria e prática. Neste trabalho buscou-se entender qual o estatuto do trabalho do professor da escola com o estágio. Discutiram-se aqui alguns conteúdos advindos do estudo bibliográfico e documental vinculados à pesquisa Recortes da Relação entre formação e atuação docente no estágio, consistindo numa interpretação que resulta da combinação cruzada de dados históricos, literatura especializada e dados obtidos na referida pesquisa. Com esse exercício, pontuaram-se diferentes flancos que sinalizam para a tese da naturalização ou invisibilidade do estágio - componente curricular obrigatório das licenciaturas. A invisibilidade ou naturalização do estágio o torna presa fácil, silenciada, senão solapada (Residência Pedagógica) pelas ações "intervenientes" (Pibid) da recente política nacional de professores do país.

\footnotetext{
${ }^{9}$ As questões não serão aprofundadas aqui, mas constituem tarefas da pesquisa.
} 


\section{Referências}

BARRA, Valdeniza Maria Lopes da. Pegadas históricas da prática de ensino e questões atuais do estágio na formação de professores. Revista Educativa. PUC/GO, 2017.

BRASIL. Decreto-Lei No 9.053, de 12 de março de 1946. Cria um ginásio de aplicação nas Faculdades de Filosofia do país. Disponível em: <http://legis.senado.gov.br/legislacao/ ListaPublicacoes.action?id=104496>. Acesso em: 14 ago. 2017.

BRASIL. Lei No 9.394, de 20 de dezembro de 1996. Estabelece as diretrizes e bases da educação nacional. Brasília: Congresso Nacional, 1996. Disponível em: <http://www.planalto. gov.br/ccivil_03/leis/L9394.htm>. Acesso em: 14 ago. 2017.

BRASIL. Resolução No 9, de 6 de agosto de 1969. Disponível em: <http://sapl.saojoaodaboavista.sp.leg.br/consultas/norma_juridica/norma_juridica_mostrar_proc?cod_nor$\mathrm{ma}=7970>$. Acesso em: 14 ago. 2017.

BRASIL, CAPES. Portaria n 096, de 18 de julho de 2013 - Aprova as regulamentações do Programa Institucional de Bolsa de Iniciação à Docência - Pibid. Disponível em : < http:// www.capes.gov.br/educacao-basica/capespibid>. Acesso em: 2 set. 2017.

BRZEZINSKI, I. Pedagogia, pedagogos e formação de professores: busca e movimento. Campinas, São Paulo: Papirus, 1996.

FAZENDA, Ivani. O papel do estágio nos cursos de formação de professores. In: PICONEZ, Stela (Coord.). A prática de ensino e o estágio supervisionado. Campinas, SP: Papirus, 1991. p. 53-62.

FUNDAÇÃO CARLOS CHAGAS. Um Estudo Avaliativo do Programa Institucional de Iniciação à Docência (Pibid). São Paulo: Fundação Carlo Chagas, 2014. Disponível em: $<$ http://www.capes.gov.br/images/stories/download/bolsas/24112014-pibid-arquivoAnexado.pdf $>$. Acesso em: 20 out. 2017.

GATTI, Bernadette A. A formação inicial de professores para a educação básica: as licenciaturas. Revista USP, São Paulo, n. 100, p. 33-46, dez./jan./fev.2013-2014. Disponível em: <http://docplayer.com.br/23764277-A-formacao-inicial-de-professores-para-a-educacao-basica-as-licenciaturas.html>. Acesso em: 14 ago. 2017.

GATTI, Bernardette A.; NUNES, Marina Muniz Rossa (Orgs.). Formação de professores para o ensino fundamental: um estudo dos currículos das licenciaturas em Pedagogia, Língua Portuguesa, Matemática e Ciências Biológicas. São Paulo: Fundação Carlos Chagas, 2009.

GATTI, Bernardette A.; TARTUCE, Gisela Lobo B. P.; UNBEHAUM, Sandra G. Formação de professores para o Ensino Fundamental: instituições formadoras e seus currículos. Estudos e pesquisas educacionais, São Paulo, Fundação Victor Civita, p.96-138, 2010. A. 
KENSKI, Vani M. A vivência escolar dos estagiários e a prática de pesquisas em estágios supervisionados. In: PICONEZ, Stela (Coord.). A prática de ensino e o estágio supervisionado. Campinas, SP: Papirus, 1991. p. 39-52.

MELO, Maria Julia Carvalho de; ALMEIDA; Lucinalva Ataíde Andrade de. Estágio supervisionado e prática docente: Sentidos das produções discursivas da ANPED, BDTD e EPENN. Revista Eletrônica de Educação, v. 8, n. 3, p. 34-51, 2014. Disponível em: $<$ http://www.reveduc.ufscar.br/index.php/reveduc/article/view/990>. Acesso em: 5 mar. 2016.

OLIVEIRA, Raquel Gomes de. Estágio supervisionado: horas de parceria escola-comunidade. Jundiaí, SP: Paco Editorial, 2011.

PIMENTA, Selma Garrido; LIMA, Socorro Lucena. Estágio e docência. São Paulo: Cortez, 2010.

PICONEZ, Stela. A prática de ensino e o estágio supervisionado: a aproximação da realidade escolar e a prática da reflexão. In: PICONEZ, Stela (Coord.). A prática de ensino e o estágio supervisionado. Campinas, SP: Papirus, 1991. p. 39-52.

RIGHETTI, Sabine. Especialistas querem residência pedagógica para docente. Folha de São Paulo, São Paulo, 4 ago. 2013. Disponível em: < http://www1.folha.uol.com.br/educacao/2013/08/1321238-especialistasquerem-residencia-pedagogica-para-docente.shtml>. Acesso em: 22 nov. 2014.

RIVAS, Noelly Prestes Padilha; PEDROSO, Cristina Cinto Araújo, BEZERRA, Delma Rosa dos Santos. O estágio supervisionado no contexto da disciplina Didática: possibilidades de formação no curso de Pedagogia. In: PACÍFICO, S. M. R.; ARAÚJO, E. S. (Orgs.). O estágio e a produção do conhecimento docente. São Carlos, SP: Pedro e João Editores, 2013.

SILVA, D. C. da. Caracterização do Centro de Ensino e Pesquisa Aplicada à Educação CEPAE/ PROGRAD/ UFG. Goiânia, Revista do CEPAE, 2017. Disponível em: https:// www.cepae.ufg.br/up/80/o/Caracterização_do_CEPAE_2017.pdf. Acesso em: 20 nov. 2017.

VEIGA, I. P. de A. Projeto político-pedagógico da escola: uma construção possível. In: Coleção Magistério: Formação e Trabalho Pedagógico. Campinas, SP: Papirus, 1995. 



\section{LETRAMENTOS DIGITAIS E FORMAČÃO INICIAL DE PROFESSORES PARA A EDUCAÇÃO ONLINE}

\section{Considerações iniciais}

O artigo é relacionado ao projeto de pesquisa "Cibercultura, Educação Online e Letramentos Digitais: desdobramentos nos processos de formação", registrado na Pró-reitoria de Pesquisa (Propeq) da Universidade Federal de Mato Grosso (UFMT), com o número 363/2017 e investiga os processos formativos (disciplinas/ módulos) nos cursos de licenciatura na modalidade de Educação a Distância $(\mathrm{EaD})$, mediados por ambientes virtuais de aprendizagem (AVA), e o alcance para o desenvolvimento de letramentos digitais $(\mathrm{LD})$.

O problema que impulsionou o estudo está relacionado a quais conhecimentos para o uso de tecnologias digitais (TD) são necessários em cursos de formação inicial de professores para promover a inclusão cibercultural dos estudantes. Esses conhecimentos para o uso de TD podem ser traduzidos como Letramentos digitais (LD) para atuar na educação online e na cibercultura?

O recorte ora apresentado tem como objetivo analisar duas formações desenvolvidas em 2012 e 2017, no curso de Licenciatura em Pedagogia, modalidade a distância, do Núcleo de Educação Aberta e a Distância (NEAD) da UFMT, observando o seu desenho didático, interfaces da plataforma virtual Modular Object-Oriented Dynamic Learning Environment (Moodle) e suas atividades, visando problematizá-las pelo viés dos letramentos digitais (LD).

O estudo tem como metodologia a pesquisa-formação na cibercultura (Santos, 2014), em diálogo com a multirreferencialidade (Ardoino, 1998), para um olhar mais complexo e heterogêneo à compreensão do fenômeno e 
suas nuances na educação. O dispositivo de pesquisa foi o AVA, suas interfaces e atividades e as possíveis relações com os LD. Essa formação não está prevista como um componente curricular no Projeto Pedagógico do Curso (PPC) analisado e sim como uma atividade introdutória ao uso do Moodle.

Os resultados do estudo são apresentados neste artigo em quatro partes. A primeira abarca os percursos das formações desenvolvidas com a implantação da plataforma Moodle no curso, aspectos relacionados à formação dos formadores, construção de desenhos didáticos e atividades da formação, mediação e interação nos processos de ensino e aprendizagem em AVA e seus desafios.

A segunda parte trata dos LD e suas dimensões e habilidades, buscando conceituá-lo à luz dos letramentos, em uma perspectiva social e por uma abordagem crítica (Street, 2014), destacando os conceitos de práticas de letramentos digitais (PLD) e eventos de letramentos digitais (ELD) em Souza (2016) e suas relações com a cultura da convergência (Jenkins, 2019), linguagens híbridas (Backthin, 2011; Santaella, 2005), aprendizagem coletiva e copresença (Lévy, 1999), virtual (Deleuze, 1996), conhecimento em rede (Castells, 1999) e educação online (Santos, 2010).

A terceira parte apresenta o desenho didático das duas formações analisadas, comparando as atividades de ambas, problematizando-as com base nas discussões sobre LD e destacando as suas potencialidades. Apontam-se, ainda, as possíveis necessidades de ampliação da formação para o alcance de LD importantes para atuar na educação online na cibercultura.

As considerações finais abordam os desafios relacionados e a formação inicial de professores com o uso de TD, as potencialidades das práticas e eventos de LD desenvolvidos, e pontos a considerar para uma formação ao longo do curso, promovendo assim a inclusão cibercultural dos estudantes futuros professores.

\section{O percurso de formação e seus desafios}

Até a sua integração à Universidade Aberta do Brasil (UAB), o curso de Licenciatura em Pedagogia, modalidade a distância, do Núcleo 
de Educação Aberta e a Distância (NEAD), da Universidade Federal de Mato Grosso (UFMT), desenvolvia a comunicação mediada por material impresso, mídias de massa como TV, vídeo, telefone, fax, $C D$ ROM, além dos encontros presenciais para estudos, avaliação e fechamento de áreas em seminários temáticos presenciais. Como destaca Oliveira (1999, p. 83), "embora os alunos possam contar no centro de apoio com diferentes meios de comunicação [...] o material utilizado é basicamente o material impresso em forma de fascículos".

A implementação da plataforma Modular Object-Oriented Dynamic Learning Environment (Moodle) no curso ocorreu em 2007. Até então, a rede comunicacional que ligava os polos entre si e estes à universidade, a estrutura física, tecnológica e acadêmica do NEAD foi de extrema importância para dar apoio às atividades de formação, contando com a instalação e manutenção de suporte técnico à rede comunicacional (Mato Grosso, 2012). Nos diferentes polos, uma infraestrutura semelhante foi implantada pelos gestores municipais para atender o projeto do curso, mediante convênios institucionais.

O ambiente virtual de aprendizagem (AVA) passa então a ser concebido como um dispositivo articulador entre os princípios epistemológicos e eixos norteadores do currículo do curso, desenvolvido na modalidade de educação a distância $(\mathrm{EaD})$. Isso impulsionou o uso desse artefato cultural para desenvolver o currículo pela educação online, trazendo novos contornos ao processo de comunicação e também à complexificação do trabalho em termos administrativos, tecnológicos, pedagógicos e de ensino e aprendizagem.

A equipe composta pela coordenação do NEAD, coordenação de curso, coordenadores pedagógicos de polo, autores de materiais didáticos, professores formadores e orientadores ${ }^{10}$ estavam diante do desafio da implementação do AVA e da construção de desenhos didáticos para as

\footnotetext{
${ }^{10} \mathrm{Na}$ proposta pedagógica do curso de Licenciatura em Pedagogia, modalidade a distância, do NEAD/UFMT, o autor (que elabora os materiais didáticos do curso) é denominado professor autor; o professor que realiza a formação (de orientadores e de estudantes) é professor formador; e o orientador da aprendizagem é chamado de orientador acadêmico. $\mathrm{Na}$ UAB, respectivamente, estes profissionais são designados por: professor conteudista, professor formador e tutor.
} 
disciplinas/áreas que fossem condizentes com a proposta do curso e, sobretudo, significativas para as aprendizagens dos estudantes, tendo em vista a base epistemológica interacionista do projeto.

Houve a reorganização da equipe do curso para coordenar áreas de AVA; multimídia; apoio aos professores autores e formadores e para a produção de material digital. Gradativamente, desenvolveu-se o diálogo com a equipe multidisciplinar da Secretaria de Tecnologia da Informação (STI), como ação fundamental "para atuar no planejamento, implementação e gestão dos cursos a distância, envolvendo docentes, tutores e pessoal técnico-administrativo"(Brasil, 2007, p. 19). Atualmente, a equipe multidisciplinar que dá suporte e apoio aos cursos de EaD, na UFMT, concentra-se na Secretaria de Tecnologia Educacional (SETEC).

Os orientadores receberam uma formação inicial juntamente com os estudantes, em 2007, um curso de extensão pela STI/UAB em "Introdução a Ambientes Virtuais de Aprendizagem: uma abordagem mediada por TIC”, envolvendo o conhecimento das funções e uso das interfaces da plataforma virtual Moodle. Essa formação foi desenvolvida também nas reofertas do curso em 2012 e 2017. Para complementar essa formação inicial, no caso dos orientadores, os encontros pedagógicos mensais contemplavam três etapas de formação: teórica - de responsabilidade dos professores autores e formadores; pedagógica - de responsabilidade da coordenação do curso e coordenações pedagógicas de polo e; tecnológica - de responsabilidade da STI/UAB que, em casos específicos, designava um apoio técnico para orientar e acompanhar os trabalhos. Atualmente essa formação é de responsabilidade da SETEC. Todavia, aos estudantes, foi oferecida somente a formação introdutória que antecedeu o início das disciplinas/áreas do curso.

Com o uso de tecnologias digitais (TD) no AVA, considerando os desafios apresentados, foi possível desenhar novos cenários pedagógicos e virtuais no curso. Como enfatizam Alonso e Onuki (2013a, p. 308), no trabalho pedagógico, para “[...] caminhar na direção de incorporar, num processo interativo e significativo, tais artefatos [...] implica reconstruir e ressignificar processos de participação, interação, enfatizando aprendizagens de natureza 
mais ativas". Nesse sentido, foi uma experiência que redimensionou a dinâmica de trabalho formativo e impulsionou o debate sobre a formação com o uso de tecnologias digitais pelo colegiado e equipe pedagógica do curso em reuniões semanais.

Das reuniões mensais da equipe pedagógica do curso com os orientadores na UFMT e destes com os estudantes nos polos, resultavam avaliações e feedbacks aos professores formadores, para a adequação das propostas das disciplinas/áreas; melhorias nos guias didáticos; revisão de critérios de avaliação de atividades no AVA; intensificação da mediação dos professores e das interações entre todos no desenvolvimento curricular pelas interfaces da plataforma virtual.

Alonso e Silva (2013b) problematizam questões relevantes sobre o uso do Moodle e contribuem com reflexões acerca da sobrecarga de trabalho docente quando são intensificados e priorizados processos de mediação, interação e interatividade qualitativos e diferenciados em AVA. Os autores destacam, também, a necessária formação e apropriação pedagógica das TICs por parte dos professores, para dar conta desses processos, tendo em vista suas especificidades e desafios.

No processo de produção de materiais impressos, de acordo com Preti (2010), cada equipe de produção imprimia a marca da sua área em consonância com os eixos norteadores do projeto pedagógico: diversidade, historicidade, construção e interação, e essa marca foi gradativamente impressa na produção do material digital, do ponto de vista da sua função, para mediar a comunicação no curso. Para a produção de materiais mais interativos e dialógicos, os professores autores e formadores receberam formações pela equipe da STI, em cursos de extensão como "Produção de Materiais Didáticos para EaD” e "Formação de Autores para EaD”. Esses cursos eram facultativos, por essa razão, nem todos os professores autores os realizaram antes de produzir materiais e atuar como formadores no curso.

O processo de concepção, construção de desenho didático e de publicação das disciplinas no AVA, inicialmente, seguiam um layout rígido, uma estrutura hierárquica e uma linguagem acadêmica. Esse formato aos poucos foi cedendo lugar à criação de designers mais plásticos e amigáveis, linguagens 
mais dialógicas e estruturas mais flexíveis e hipertextuais. Com essa organização, os estudantes puderam vivenciar caminhos menos lineares para suas experiências de aprendizagens. Esse processo foi lento e desafiador para a equipe do curso e ainda continua sendo, pois exige dos professores formadores o domínio das especificidades das interfaces da plataforma Moodle para explorar as suas potencialidades pedagógicas, o que nem sempre ocorre.

Conforme Maciel (2013), é cada vez mais comum cursos híbridos, que contemplam materiais impressos, digitais, audiovisuais etc. Nesse sentido, é necessária a familiarização com as particularidades estruturais e interativas das interfaces digitais, pois mesmo àqueles com maior grau de letramento digital, o uso de um ambiente virtual para fins pedagógicos requer o reconhecimento de sua especificidade. Para o autor, o planejamento, acompanhamento, interação, mediação e avaliação de atividades de aprendizagem em AVA requerem a compreensão, por parte do professor, acerca do seu funcionamento, sendo fundamental a composição de equipes de especialistas das áreas de informática e de educação para atuar juntos nesses processos.

Gradativamente, as coordenações e colegiado de curso foram organizando linhas de ações para nortear os percursos de formação em "Orientações Gerais ao professor Formador", "Orientações Gerais para Elaboração de Plano Didático e Guia de Estudo”, em sintonia com o projeto do curso. Outras orientações foram organizadas pelas coordenações $\mathrm{UAB}$, juntamente com as coordenações de cursos da $\mathrm{EaD}$, igualmente importantes, como "O Sistema de Orientação na Modalidade a Distância - UFMT”, “Orientações Técnicas e Pedagógicas aos Autores de Materiais Didáticos (MDI)" e "Funções e Responsabilidades dos Atores Envolvidos em EaD UFMT". Esse conjunto de documentos foi discutido e disponibilizado aos professores formadores no AVA do curso no "Espaço Acadêmico - Sala de Planejamento".

A mediação humana para interagir no processo de comunicação com as interfaces do AVA constituiu uma preocupação que não se esgotou no processo de implementação da plataforma Moodle. Ainda hoje continua 
sendo um desafio, porque esse dispositivo não se limita a um repositório de conteúdos e informações. As suas potencialidades de diálogo, negociações e fluxos de experiências ativas, interativas, colaborativas e de cocriação são mediadas pela ação humana em interação recíproca com o outro, para mobilizar aprendizagens e construir conhecimentos.

As noções de interação e de interatividade são pontos relevantes quando se trata de comunicação mediada por AVA na educação online, seja para a educação presencial, seja para a EaD. O objetivo de promover aprendizagens, conforme Santos (2014), pressupõe que ambos os polos da comunicação (professores e estudantes) estejam em atuação constante, mediatizados pelo meio físico (computador) e virtual (AVA), para que haja influência recíproca. $\mathrm{O}$ "princípio da interação e da interatividade é fundamental para o processo de comunicação e devem ser garantidos no uso de qualquer meio tecnológico a ser disponibilizado" (Brasil, 2007, p. 10).

É imprescindível também levar em conta a noção de mediação, pois, segundo Neder e Possari (2009, p. 18), “[...] a relação professor-aluno não se estabelece mais face a face, mas, sim, pela mediação de textos, veiculados pelas tecnologias da informação e da comunicação". Tal mediação redimensiona a dinâmica e o processo, em sua dupla dimensão: como dispositivo pedagógico e como objeto de estudo. As autoras destacam, ainda, que o AVA enfatiza a comunicação interativa e o caráter ativo e mediador dos sujeitos na/da ação comunicativa, tendo em vista que nesse processo modifica-se sensivelmente o papel e a função dos envolvidos.

$\mathrm{O}$ uso de dispositivos e interfaces digitais em práticas sociais, a qualquer hora e em qualquer lugar, aciona múltiplas funções e linguagens. Essas práticas impõem à educação outras maneiras de desenvolver o currículo, e as práticas pedagógicas e de ensino e aprendizagem, especialmente no que se refere ao uso competente do digital em rede na educação online - fenômeno este que surge e ganha sentido nas práticas formativas em tempos de cibercultura - são também chamadas de letramentos digitais, conforme discutiremos no próximo tópico. 


\section{Letramentos Digitais: dimensões e habilidades}

$\mathrm{Na}$ cultura da convergência, conforme Jenkins (2009), os processos são operados por forças combinadas de tecnologias antigas e novas interagindo de forma dinâmica e simultânea na rede mundial e por dispositivos diversos. Para o autor, o local e o global se entrecruzam, e consumidores e indústrias conduzem o processo conjuntamente, implicando mudanças significativas na lógica pela qual a cultura também opera, com ênfase no fluxo de informações que circulam pelos múltiplos canais de mídia.

Junto com esse processo, como aponta Santaella (2005), abre-se um leque para as linguagens híbridas ${ }^{11}$ que são desdobramentos de três matrizes da linguagem: visual, sonora e verbal, e se desdobram na multi e hipermídia e na multi e hipermodalidade de gêneros textuais que compõem os caminhos do bipertexto. Nesse processo, recorrendo a Bakhtin (2011), as linguagens formam uma rede de sentidos polifônicos e multiformes nos processos de comunicação, impondo outra lógica na interatuação dos sujeitos que operam com o digital em rede.

O percurso de aprendizagens é colaborativo e vivenciado em copresença, no sentido da virtualidade (Levy, 1999), dos meios, dos sujeitos e das mensagens. $\mathrm{O}$ acesso a diferentes dispositivos e interfaces passa do possível e imediato para o virtual e ilimitado. O virtual, para Deleuze (1996) implica elementos atuais e virtuais, reagindo um sobre o outro, em circuitos moventes, mutantes, proliferantes e em troca perpétua, pois o virtual é potência, transferência virótica, multiplicidade, redes sem fronteiras.

A universidade, como uma estrutura social baseada em redes (Castells, 1999), opera com tecnologias que geram, processam e distribuem informações a partir do conhecimento acumulado entre os nós dessas redes que transcendem fronteiras. Desse modo, é imperativo buscar modos flexíveis, adaptáveis e descentralizadores para partilhar tomadas de decisão, pois se alteram os códigos de vida humana e a organização das práticas sociais.

\footnotetext{
${ }^{11}$ Linguagens híbridas são informações não lineares como a escrita, símbolos matemáticos, notações, diagramas, figuras, elementos audiovisuais - voz, música, sons, imagens fixas e animadas (Santaella, 2005).
} 
Nos processos de formação, a prática da educação online é uma realidade que se expande em práticas de currículos em tempos de cibercultura, ou seja, na cultura atual.

Para Santos (2010), a educação online é um fenômeno da cibercultura, ou seja, da cultura contemporânea estruturada pelas tecnologias digitais em rede. Para a autora, a educação online é um conjunto constituído por ações de aprendizagem, atos de currículo mediados principalmente pelas tecnologias dos ambientes virtuais de aprendizagem (AVA), que potencializam práticas comunicacionais interativas e hipertextuais em espaços multirreferenciais de aprendizagem, com sujeitos geograficamente dispersos.

Promover aprendizagens e inclusão cibercultural requer que as práticas curriculares, pedagógicas e de ensino e aprendizagem contemplem e potencializem, conforme Souza (2016), os letramentos digitais (LD), como práticas sociais amplas e diversas com o uso do digital em rede. A autora aponta que, nesse processo, diversas dimensões dos LD estão presentes como a autogestão do tempo; autodireção da aprendizagem; funcional (técnico-operacional); sensório-motor-digital; comunicacional; comunicação online; informacional; pedagógica; cognitiva; linguística; social; intercultural e, no interior delas, há habilidades importantes para o uso do AVA, sendo mobilizadas e potencializadas nas práticas sociais.

Para o uso, apropriação, consumo e produção, com o digital em rede, os conceitos de letramento digital (LD), práticas de letramentos digitais (PLD) e eventos de letramentos digitais (ELD), conforme Souza (2016), se tornam fundamentais, em especial, se ancorados em uma perspectiva social e uma abordagem crítica dos letramentos na educação (Street, 2014).

Quadro 1 - Conceituação de Letramentos Digitais (LD), Práticas de Letramentos Digitais (PLD) e Eventos de Letramentos Digitais (PLD)

\begin{tabular}{|c|l|}
\hline LD & $\begin{array}{l}\text { Leva em conta as práticas contextualizadas social, cultural e } \\
\text { historicamente, consoante a cultura atual, a cibercultura, e exige a } \\
\text { abertura para a formação do pensamento, da crítica e da autonomia } \\
\text { dos sujeitos. }\end{array}$ \\
\hline
\end{tabular}




\begin{tabular}{|l|l|}
\hline PLD & $\begin{array}{l}\text { São contextualizadas social, política, econômica e culturalmente, } \\
\text { envolvendo identidade, discurso e poder, os quais configuram } \\
\text { e determinam a sua interpretação e atribuição de sentido pelos } \\
\text { participantes, em eventos mediados por mídias digitais (MD), que } \\
\text { mobilizam um conjunto amplo de conhecimentos, habilidades, meios, } \\
\text { gêneros e linguagens circunstanciadas pelo contexto sócio histórico do } \\
\text { discurso e das condições de produção. }\end{array}$ \\
\hline ELD & $\begin{array}{l}\text { É uma situação em que um suporte, portador ou interface digital } \\
\text { se torna parte integrante da interação entre os participantes e seus } \\
\text { processos interpretativos e se constitui por meio de práticas sociais mais } \\
\text { amplas de uso de mídias digitais (MD) em contextos comunicativos, } \\
\text { como instâncias de uso de MD em que a mensagem digital é a sua } \\
\text { materialização. }\end{array}$ \\
\hline
\end{tabular}

Fonte: Souza (2016)

Seguindo a perspectiva dos letramentos como práticas sociais amplas (Street, 2014), é salutar, conforme aponta Souza (2016), a busca por uma abordagem alternativa e crítica dos $\mathrm{LD}$, que focalize o seu caráter ideológico e múltiplo, incorporando conceitos de cultura, poder, identidade, agência e discurso. A autora destaca que as PLD, em espaços sociais, são amplas e diversas e, na universidade, o processo formativo como um todo pode ser concebido como PLD, no contexto das práticas curriculares dos cursos; os ELD são as aulas e atividades formativas e, no interior delas, são mobilizadas dimensões dos LD que, por sua vez, possibilitam desenvolver nos estudantes habilidades específicas para atuar com o digital em rede.

No próximo item, analisamos a formação desenvolvida no curso de Pedagogia EaD, do NEAD/UFMT, concebendo-a como PLD e ELD, destacando o seu potencial para mobilizar LD nos estudantes.

\section{AVA como dispositivo mobilizador de letramentos digitais na educação online}

A formação "Introdução e Ambientação do Moodle", ministrada no ano de 2012, como atividade introdutória ao curso de Licenciatura em Pedagogia, modalidade a distância do NEAD/UFMT, objetivou levar o estudante a "conhecer as principais ferramentas a serem utilizadas no con- 
texto do curso da UAB através de um estudo paralelo sobre a plataforma Moodle - Modular Object-Oriented Dynamic Learning Environment".

Essa formação foi organizada com uma etapa de quatro horas presenciais nos polos de $\mathrm{EaD}$ e uma etapa a distância de uma semana pelo AVA. As atividades da primeira etapa da formação foram propostas com orientações por tutoriais acerca de dados cadastrais, senha de acesso, criação de perfil, envio de mensagens via email, fóruns, chats, envio de arquivo, texto colaborativo na wiki e calendário.

As atividades da segunda etapa destinaram-se ao uso das interfaces exploradas no momento presencial da formação e também para sanar as dúvidas dos estudantes. Um contato direto com o apoio tecnológico foi também disponibilizado no AVA, em caráter permanente, aos estudantes.

Nas atividades presenciais, de apresentação e exploração das interfaces do AVA, o objetivo foi levar o estudante a operar a plataforma Moodle com a mediação de um técnico, promovendo a interação entre ele e os professores formadores. Essa formação foi oferecida também aos orientadores do curso, concomitantemente, aos estudantes. Gradativamente, foi feita a inserção de outras práticas de comunicação com o uso de webconferência e hangout, para dinamizar a comunicação síncrona. Essas atividades são descritas no quadro a seguir:

Quadro 1 - Formação "Introdução e Ambientação do Moodle" - 2012

\begin{tabular}{|c|l|}
\hline $\begin{array}{c}\text { Atividades } \\
\text { (presenciais) }\end{array}$ & \multicolumn{1}{c|}{ Ações/domínios } \\
\hline $\begin{array}{c}\text { Checando } \\
\text { dados } \\
\text { cadastrais }\end{array}$ & $\begin{array}{l}\text { - Ir ao menu participantes; clicar sobre o seu nome; verificar } \\
\text { dados cadastrais; fazer a atualização. } \\
\text { - Clicar sobre os nomes dos colegas de sala; verificar seus perfis; } \\
\text { ajudar os colegas com dificuldade com o auxílio do orientador/tutor. }\end{array}$ \\
\hline $\begin{array}{c}\text { Enviando e } \\
\text { recebendo } \\
\text { mensagens }\end{array}$ & $\begin{array}{l}\text { - Ir a ferramenta participantes; escolher um dos colegas; enviar } \\
\text { - Repetir o procedimento anterior e enviar uma mensagem para } \\
\text { - Clicar em exibir uma mensagem de seu colega; } \\
\text { - Acessar o link "histórico" para evidenciar as mensagens } \\
\text { trocadas com seus colegas. }\end{array}$ \\
\hline
\end{tabular}




\begin{tabular}{|c|c|}
\hline $\begin{array}{c}\text { Atividades } \\
\text { (presenciais) }\end{array}$ & Ações/domínios \\
\hline $\begin{array}{l}\text { Envio de } \\
\text { Arquivo } \\
\text { Único }\end{array}$ & $\begin{array}{l}\text { - Abrir seu editor de textos; digitar um texto com no mínimo } \\
\text { três linhas, respondendo à seguinte questão: Qual sua } \\
\text { disponibilidade de tempo para estudar durante a semana? } \\
\text { - Gravar esse arquivo com identificação do nome do texto em } \\
\text { seu computador; criar uma pasta específica para esse propósito } \\
\text { no computador; } \\
\text { - Voltar ao ambiente virtual; clicar na atividade para anexar um } \\
\text { arquivo; } \\
\text { - Fazer comentários e também atribuir uma nota pela atividade } \\
\text { que enviou; } \\
\text { - Localizar qual comentário e nota que recebeu por essa } \\
\text { atividade. }\end{array}$ \\
\hline $\begin{array}{l}\text { Envio Mais } \\
\text { de Um } \\
\text { Arquivo }\end{array}$ & $\begin{array}{l}\text { - Escolher no computador local ou na Internet dois } \\
\text { documentos no formato .doc ou .pdf. } \\
\text { - Enviar os arquivos, separadamente, para a plataforma } \\
\text { utilizando a opção envio. }\end{array}$ \\
\hline $\begin{array}{l}\text { Fóruns com } \\
\text { Tópicos de } \\
\text { Apresentação }\end{array}$ & $\begin{array}{l}\text { - Clicar no botão "Acrescentar um novo tópico de discussão e } \\
\text { criar um tópico de apresentação (nome, formação, profissão e } \\
\text { suas expectativas quanto ao curso à distância); } \\
\text { - Entrar em um tópico de um colega, clicar em "responder" e } \\
\text { comentar a contribuição. }\end{array}$ \\
\hline $\begin{array}{l}\text { Usando a } \\
\text { ferramenta } \\
\text { Bate Papo } \\
\text { (Chat) }\end{array}$ & $\begin{array}{l}\text { - Acessar o Bate Papo e participar de um debate com a } \\
\text { seguinte pauta: } \\
\text { 1) Qual a sua experiência com informática básica e quais são } \\
\text { suas dificuldades (se tiver)? } \\
\text { 2) Ao final do debate (com a condução do Tutor/Orientador) } \\
\text { tente encerrar com a seguinte conclusão: Como em grupo, } \\
\text { poderíamos nos ajudar a romper essas barreiras de forma a } \\
\text { obter o máximo sucesso no curso? } \\
\text { - Após o debate: sair da ferramenta e tentar acessar novamente, } \\
\text { clicando em "Sessões Encerradas". }\end{array}$ \\
\hline $\begin{array}{l}\text { Construindo } \\
\text { Textos } \\
\text { Colaborativos } \\
\text { (Wikipédia) }\end{array}$ & $\begin{array}{l}\text { - Acessar a ferramenta wikipédia e postar uma resposta para } \\
\text { seguinte questão: } \\
\text { 1) Que informação (palavras) vem em sua mente quando escuta } \\
\text { a frase: Educação a Distância? } \\
\text { 2) Escrever no máximo } 3 \text { ou } 4 \text { palavras e ao lado coloque seu } \\
\text { nome entre parênteses. } \\
\text { - Sair da wikipédia e entrar novamente; } \\
\text { - Visualizar as contribuições dos colegas. }\end{array}$ \\
\hline
\end{tabular}




\begin{tabular}{|c|c|}
\hline $\begin{array}{l}\text { Atividades } \\
\text { (presenciais) }\end{array}$ & Ações/domínios \\
\hline $\begin{array}{l}\text { Orientações } \\
\text { sobre uso da } \\
\text { ferramenta } \\
\text { calendário }\end{array}$ & $\begin{array}{l}\text { - Ir até o canto superior direito da sua interface na ferramenta } \\
\text { "Calendário"; exibir meses e seus respectivos dias; clicar na seta } \\
\text { para esquerda e para direita que permitem um movimento entre } \\
\text { os meses do ano; } \\
\text { - Abrir uma caixa intitulada "Próximos Eventos"; } \\
\text { - Inserir um evento pessoal (Evento do usuário) com os } \\
\text { seguintes procedimentos: } \\
\text { 1) Escolher quatro dias subsequentes ao atual no calendário da } \\
\text { ferramenta; agendar para cada um desses dias uma atividade - } \\
\text { Exemplo: dia } 18 \text { - Entregar a atividade X, dia } 19 \text { - Entregar a } \\
\text { atividade Y e assim por diante. } \\
\text { 2) Verificar as cores diferenciadas na ferramenta e exibir } \\
\text { "próximos eventos". }\end{array}$ \\
\hline $\begin{array}{l}\text { Atividades } \\
\text { (a distância) }\end{array}$ & Ações/domínios \\
\hline \multicolumn{2}{|c|}{$\begin{array}{l}\text { As atividades propostas não serão avaliadas, porém, é interessante que seja feito } \\
\text { esse percurso a fim de sanar as possíveis dúvidas quanto ao uso do ambiente } \\
\text { virtual. }\end{array}$} \\
\hline $\begin{array}{l}\text { Enviando e } \\
\text { Recebendo } \\
\text { Mensagem }\end{array}$ & $\begin{array}{l}\text { - Ir até a ferramenta participantes, escolher um de seus colegas } \\
\text { e enviar uma mensagem falando sobre a capacitação que } \\
\text { recebeu. }\end{array}$ \\
\hline $\begin{array}{l}\text { Tarefa com } \\
\text { Envio de } \\
\text { Arquivo } \\
\text { Único }\end{array}$ & $\begin{array}{l}\text { - Assistir ao vídeo e, a partir da leitura, produzir um pequeno } \\
\text { texto, com suas considerações e entendimento sobre a } \\
\text { temática proposta. } \\
\text { - Salvar o arquivo em seu computador; } \\
\text { - Anexar ao ambiente clicando no botão "enviar este arquivo". }\end{array}$ \\
\hline $\begin{array}{l}\text { Tarefa } \\
\text { com Envio } \\
\text { de Vários } \\
\text { Arquivos }\end{array}$ & $\begin{array}{l}\text { - Fazer uma pesquisa no google sobre as tecnologias na } \\
\text { educação; } \\
\text { - Salvar o conteúdo em um arquivo no formato .doc no } \\
\text { computador } \\
\text { - Fazer outra pesquisa no google sobre aprendizagem } \\
\text { colaborativa; } \\
\text { - Salve o conteúdo em um arquivo no formato .pdf no } \\
\text { computador; } \\
\text { - Enviar os dois arquivos, separadamente, para a plataforma } \\
\text { utilizando a opção "enviar arquivo". }\end{array}$ \\
\hline
\end{tabular}




\begin{tabular}{|c|l|}
\hline $\begin{array}{c}\text { Atividades } \\
\text { (presenciais) }\end{array}$ & \multicolumn{1}{c|}{ Ações/domínios } \\
\hline & $\begin{array}{l}\text { Nas atividades de Compreensão presencial, de que participou } \\
\text { da atividade Fórum, com tópicos gerais. Exercitar mais um } \\
\text { pouco essa atividade, só que com uma única discussão simples. } \\
\text { - Ler ao enunciado: } \\
\text { "No meu entender, é preciso, ao se falar em EAD, situá-la } \\
\text { em uma amplitude maior do que as que temos encontrado } \\
\text { mais frequentemente. Temos pensado a EAD a partir de } \\
\text { sua adjetivação. O termo “a distância" tem catalisado nossas } \\
\text { reflexôes em detrimento de sua essência. O que importa, no } \\
\text { meu entender, é esclarecer a compreensão que temos sobre a } \\
\text { Educação, sua dimensão político-social. Antes de pensarmos } \\
\text { a respeito da modalidade pelo qual o processo educativo } \\
\text { será desenvolvido (presencial, a distância, semipresencial } \\
\text { etc.), é preciso que discutamos que projeto de sociedade } \\
\text { temos, que papel a educação escolar pode desempenhar nesse } \\
\text { simplentido" (Maria Lúcia C. Neder). } \\
\text { - Clicar em “Responder”; } \\
\text { - Escrever suas considerações/comentários; } \\
\text { - Finalizar clicando no botão "Enviar mensagem ao fórum"; } \\
\text { - Comentar a resposta dos colegas. }\end{array}$ \\
\hline
\end{tabular}

Fonte: http://200.129.241.90/moodleped12/course/view.php?id=3

A formação "Introdução ao Ambiente Virtual Moodle", ministrada no ano de 2017, no mesmo curso, de modo geral manteve o desenho didático descrito no quadro anterior. O Objetivo foi "apresentar as possibilidades e recursos que a plataforma Moodle oferece para a prática discente, contribuindo para o enriquecimento das estratégias de aprendizagem no contexto da educação a distância". O tempo da formação foi o mesmo da anterior. A apresentação do curso e os tópicos desenvolvidos na formação podem ser visualizados nas figuras 1 e 2 a seguir: 
Figura 1 - Formação "Introdução ao Ambiente Virtual de Aprendizagem Moodle"- 2017
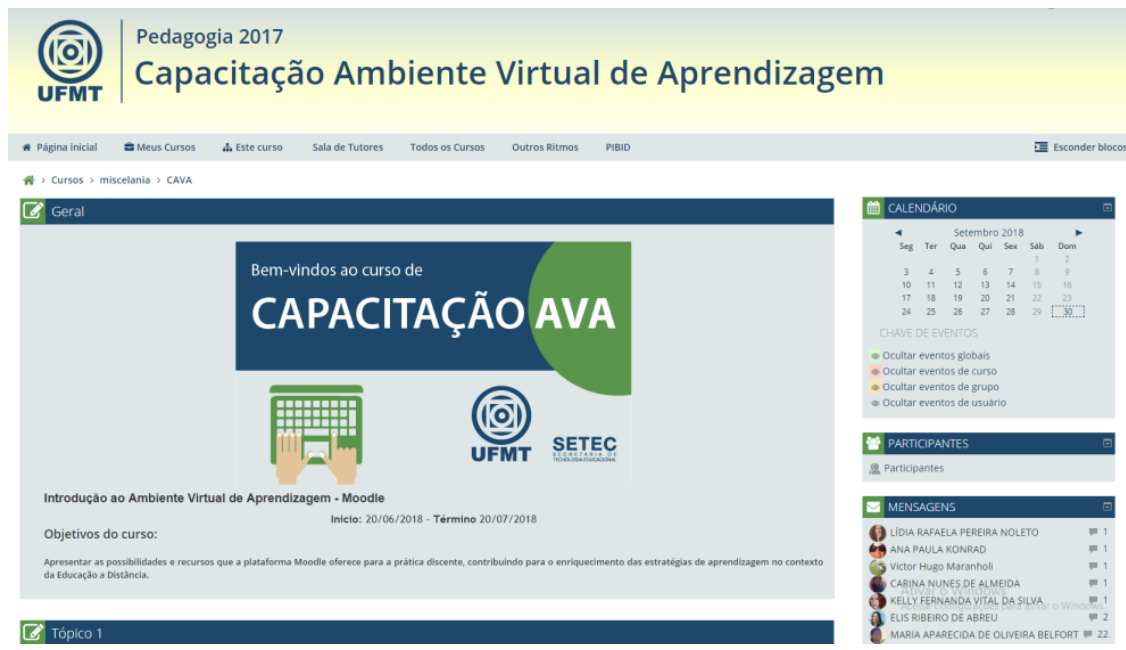

Fonte: https://setec.ufmt.br/ava/lic-ped/course/view.php?id=3

As atividades e conteúdos foram estruturados em dois tópicos: o tópico 1 , com textos complementares, e o tópico 2, com atividades de compreensão (presencial). Pelo que consta no AVA, a parte de textos complementares foi planejada para subsidiar as atividades a serem feitas no decorrer do curso, ou seja, na etapa a distância.

Figura 2 - Página inicial da formação

\section{Tópico 1}

Textos Complementares:

A seguir apresentaremos alguns textos que permitirão fundamentos mínimos para o desenvolvimento das atividades durante o curso.

F. Texto A - Como alterar seus dados cadastrais?

Texto B - Como alterar senha?

Texto C - Como enviar mensagens?

Texto D - Como responder tarefas eletrônicas (Texto online ou Envio de Arquivo)

Texto E - Como participar de um fórum?

Texto F-Como usar uma ferramenta de bate papo?

Texto G - Como funciona as Questões Eletrônicas 
Atividades de Compreensão (presencial)

A seguir apresentaremos algumas atividades para você exercitar o uso de ferramentas do ambiente virtual de aprendizagem Moodle

(5) Atividade 1 - Checando seus dados cadastrais

들 Atividade 2 - Alterando sua senha

들 Atividade 3 - Enviando e Recebendo Mensagens

咺 Atividade 4 - Fórum de discussão simples

I Atividade 5 - Tarefa texto online

19. Atividade 6 - Envio de arquivos

든 Atividade 7 - Usando a ferramenta Calendário

扈 Atividade 8 - Usando Fórum Geral

A. Atividade 9 - Usando a ferramenta Bate Papo (Chat)

Atividade 10 - Questionários

Fonte: https://setec.ufmt.br/ava/lic-ped/course/view.php?id=3

Ao comparar os tópicos da Figura 2, do curso de 2017, com o Quadro 1, do curso de 2012, percebemos o acréscimo dos itens: alterar senha, ferramenta calendário e tarefa de textos online ou questionário eletrônico. Essas interfaces são usadas nas disciplinas/áreas e é fundamental que façam parte da formação. Por outro lado, na formação do curso de 2017 há a ausência da interface chat, para a comunicação síncrona, e da interface wiki, para a elaboração de textos coletivos e colaborativos, o que representa uma perda em termos de uso e apropriação das potencialidades dessas interfaces do AVA.

As possíveis dimensões dos $\mathrm{LD}$ com o uso do digital em rede no AVA, mobilizadas nas duas formações, podem ser observadas, segundo Souza (2016), em atividades como:

a) alterar senha, acessar dados cadastrais, enviar arquivos - dimensão funcional (técnico e operacional) para auxiliar o estudante no uso instrumental das interfaces de comunicação do Moodle; acessar calendário e abrir documentos - dimensões comunicacional e pedagógica para levar o estudante a conhecer o espaço virtual do curso, sabendo localizar, baixar, selecionar e armazenar documentos. 
Essa seria a primeira etapa da inclusão digital dos estudantes, podendo ser ampliada para a dimensão informacional dos $\mathrm{LD}$, em que a pesquisa e busca na internet pode promover o contato com linguagens híbridas, como destaca Santaella (2005), em que o hipertexto e a hipermodalidade de gêneros estão presentes.

b) enviar e responder mensagens em fóruns e interagir em um chat - dimensões comunicacional, gestão do tempo, linguística e social dos LD para levar e estudante a desenvolver habilidades de comunicação online para interagir com os outros, considerando o conteúdo e as características das mensagens, regras de etiqueta para a conversação online, afetividade e emoções nas ações interacionais; espaço-temporal da comunicação síncrona e o fortalecimento da identidade com o curso e com o grupo.

De certo modo, para essa dimensão dos LD, acentua-se e relevância da estrutura física e humana baseada em redes flexíveis e adaptáveis, de acordo com Casttels (1999), bem como conceber os letramentos na cibercultura em uma perspectiva social e uma abordagem crítica, conforme Street (2014), em que os conceitos de identidade e discurso são fundamentais.

c) interface wiki-dimensões linguística, cognitiva e social dos LD, para levar o estudante a perceber a habilidade de produzir textos/ discursos sobre determinado tema/conceito, perceber as características discursivas do texto/mensagem e os aspectos da interação com os outros, para produzir em colaboração e cocriação.

Trata-se de um espaço importante de copresença, formação de comunidade de aprendizagem e inteligência coletiva, como aponta Levy (1999). Nesse sentido, a formação oferecida no início do curso cumpre o papel da inclusão digital dos estudantes para atuar na educação online mediada pelo uso do AVA.

$\mathrm{Na}$ fase inicial da formação inicial de professores, é importante que se apresentem as potencialidades de todas as interfaces do AVA, destacando que elas são disparadoras de dimensões dos LD, que podem potencializar habilidades já existentes e mobilizar novas habilidades, na medida em que o uso se complexifica. Com um desenho didático redimensionado pelo 
viés dos $\mathrm{LD}$, as formações analisadas podem ampliar processos interativos e hipertextuais, em que a educação online, como aponta Santos (2010), pode favorecer práticas comunicativas e interacionais que promovem a inclusão cibercultural dos sujeitos.

$\mathrm{Na}$ edição do curso de 2017, ainda que timidamente, foi acrescido o uso da webconferência pelo Skype, para viabilizar a comunicação síncrona, bem como a formação de grupos no watsapp, para as comunicações síncronas e assíncronas entre orientadores e estudantes sobre o processo de ensino e aprendizagem. A formação de grupos de professores formadores e orientadores pelo whatsapp, para questões pedagógicas sobre cada disciplina/área, ocorreu mais recentemente em 2019, com ações condizentes com a cultura da convergência (Jenkins, 2009) e da comunicação ubíqua que vivemos na atualidade.

Em uma perspectiva dos letramentos como práticas sociais amplas, em que cultura, identidades, poder, discursos (Street, 2014) estejam presentes, amplia-se também o papel da universidade como agência promotora de conhecimentos e a formação vai além do uso e consumo de TD, focalizando os atos de currículo na apropriação e produção de conhecimentos autorais e críticos, com o digital em rede.

\section{Considerações finais}

O objetivo do estudo foi fazer uma análise de duas formações destinadas a estudantes de licenciatura para o uso das interfaces do AVA, destacando suas potencialidades como disparadoras de dimensões de letramentos digitais (LD) e mobilizadoras de habilidades a elas relacionadas.

O problema que impulsionou o estudo está relacionado aos conhecimentos necessários à formação inicial de professores para o uso de tecnologias digitais (TD) e para o desenvolvimento $\mathrm{LD}$, a fim de atuar de maneira competente na educação online e promover a inclusão cibercultural dos estudantes.

As formações para o uso de TD, mediadas por AVA, que analisamos contemplam conhecimentos relacionados às principais interfaces da 
plataforma Moodle e, nesse sentido, desenvolvem dimensões como a funcional, comunicacional, pedagógica, gestão do tempo, linguística e social dos LD que correspondem à primeira etapa da inclusão digital dos estudantes e orientadores para iniciar o curso.

A questão é que essa formação não se estende aos professores formadores que atuam no curso. E, para esses profissionais que atuam diretamente no acompanhamento de orientadores e estudantes, não conhecer as potencialidades comunicativas e pedagógicas das interfaces do AVA pode comprometer a mediação a ser feita no desenvolvimento dos componentes curriculares e a interação com os grupos envolvidos, o que constitui uma lacuna e um desafio a ser superado.

Outro desafio é ampliar o desenho didático da formação para outras dimensões dos LD que fazem parte do cotidiano cibercultural na atualidade. A título de exemplificação, o LD informacional é importante e potencializa as buscas e consultas de informações na internet, sabendo avaliar as mensagens e suas fontes. O LD de autogestão da aprendizagem pode ser desenvolvido por meio de um diário online ou um blog com narrativas, imagens, significados e sentidos acerca das aprendizagens; o LD intercultural, por meio de espaços de uso social, pode promover trocas culturais entre os estudantes de contextos multirreferenciais diversos, usando fotografias, produção de vídeos, memes e outros dispositivos que podem contribuir para mobilizar novas habilidades de LD.

Um processo formativo com as características dos $\mathrm{LD}$, concebidos como práticas sociais, e eventos que ocorrem continuamente em processos formativos na universidade, requer a revisão de currículos, desenhos didáticos plásticos e flexíveis para as disciplinas, tempo ampliado para a formação contínua e a ênfase na inclusão cibercultural dos sujeitos envolvidos para uma atuação ativa e crítica em práticas sociais.

\section{Referências}

ALONSO, Katia Morosov; ONUKI, Daisuki. Trajetórias e percursos em Educação a Distância: entre o sol nascente e o poente. In: MILL, Daniel; MACIEL, Cristiano. Educação a distância: elementos para pensar o ensino-aprendizagem contemporâneo. Cuiabá: EdUFMT, 2013a. 
ALONSO, Katia Morosov; SILVA, Danilo Garcia. Trabalho Docente, Educação a Distância e as TICs: entre a excitação e o sobretrabalho. Linhas Críticas, Brasília, DF, v.19, n.40, p. 561-578, set./dez.2013b.

ARDOINO, Jacques. Abordagem multirreferencial (plural) das situações educativas e formativas. In: BARBOSA, J. (Org.). Multirreferencialidade nas ciências e na Educação. São Carlos: EDUFScar, 1998.

BAKTHIN, Mikhail. Estética da criação verbal. São Paulo: Editora WMF Martins Fontes, 2011.

BRASIL. Referenciais de qualidade para a Educação Superior a Distância. Ministério da Educação Secretaria de Educação a Distância, 2007.

CASTELLS, Manuel. A Sociedade em Rede. São Paulo: Paz e Terra, 1999.

DELEUZE, Gilles. O Atual e o Virtual. In : DELEUZE, Gilles; Claire PARNOT. A filosofia virtual. Dialoques. Paris: Flammarion, 1996.

JENKINS, Henry. Cultura da convergência. 2.ed. São Paulo: Aleph, 2009.

LEVY, Pierre. Cibercultura. São Paulo: Ed. 34, 1999.

MACIEL, Cristiano (Org.). Educação a Distância: ambientes virtuais de aprendizagem. Cuiabá: EdUFMT, 2013.

MATO GROSSO. Universidade Federal de. Universidade Aberta do Brasil. Projeto do Curso de Licenciatura em Pedagogia - Modalidade a Distância. Cuiabá: EdUFMT, 2012.

NEDER, Maria Lucia Cavalli. Material Didático e o Processo de Comunicação na EAD. In: POSSARI, Lucia Helena Vendrúsculo; NEDER, Maria Lucia Cavalli. Material Didático para a EaD: processo de produção. Cuiabá: EdUFMT, 2009.

OLIVEIRA, Maynara. A Educação a Distância e Licenciatura Plena em Educação Básica: uma experiência inovadora. In: Cadernos de Educação UNIC. Coordenação de Pós-Graduação. v.1, 1999.

PRETI, Oreste. Material Didático Impresso na EaD: experiências e lições apre(e)ndidas. In: MILL, Daniel; PIMENTEL, Nara (Org.). Educação a Distância: desafios contemporâneos. São Carlos, SP: EdUFSCar, 2010.

SANTAELLA, Lucia. Matrizes da linguagem e pensamento: sonora, visual e verbal. 3. ed. São Paulo: Iluminuras: FAPESP, 2005.

SANTOS, Edméa. Pesquisa-Formação na cibercultura. Santo Tirso PT: WHITEBOOKS, 1994. 
SANTOS, Edméa. Educação Online para Além da EaD: um fenômeno da cibercultura. In: SILVA, Marco; PESCE, Lucila; ZUIN, Antonio (Orgs.). Educação Online: cenário, formação e questões didático metodológicos. Rio de Janeiro: Wak Editora, 2010.

SOUZA, Terezinha Fernandes Martins de. Ondas em ressonância: Letramentos digitais de estudantes na Universidade Aberta de Portugal. 2016. Tese (Doutorado em Educação) - Centro de Educação do Programa de Pós-graduação em Educação, Universidade Federal de Santa Catarina, 2016.

STREET, Brian. Letramentos Sociais: abordagens críticas do letramento no desenvolvimento, na etnografia e na educação. Tradução: Marcos Bagno. São Paulo: Parábola Editorial, 2014. 



\section{Sobre os autores}

\section{Neide Borges Pedrosa}

Doutora em Educação pela Pontifícia Universidade Católica de São Paulo. Professora Adjunta da Universidade Federal de Rondônia/UNIR, lotada no Departamento de Ciências da Educação, Campus José Ribeiro Filho, em Porto Velho/RO. Coordenadora do Labmídia. Membro do Grupo de Pesquisa Multidisciplinar em Educação e Infância - EDUCA Coordenando a linha de pesquisa - Práticas pedagógicas, inovações curriculares e tecnológica.

\section{Rogéria Moreira Rezende Isobe}

Doutora em Educação pela Pontifícia Universidade Católica de São Paulo. Atualmente é professora associada do Departamento de Educação da Universidade Federal do Triângulo Mineiro (UFTM). Desenvolve atividades de ensino nos cursos de Licenciatura bem como atividades de extensão e pesquisa com foco nos seguintes temas: História da Educação, Cultura e Educação, Políticas Educacionais voltadas para o trabalho docente, reconhecendo o caráter essencialmente histórico dos processos que envolvem a temática.

\section{Andréa Rodrigues de Souza}

Pós-graduanda em Educação Especial/Inclusiva pela Universidade Estadual do Maranhão (UEMA). Membro do Grupo de Estudos, Pesquisas, Educação, Infância \& Docência (GEPEID). Atualmente é professora de Educação Infantil da Secretaria Municipal de Educação (SEMED-São Luís). Foi Supervisora do Curso de Extensão em Docência em Educação Infantil (CEEI) (2015) e Ex-Bolsista do Programa Institucional de Bolsas de Iniciação à Docência PIBID/CAPES/UFMA (2011-2015). 


\section{Elizabeth Regina Streisky de Farias}

Doutora em Educação pela Universidade Estadual de Ponta Grossa (UEPG). Atualmente é professora no Departamento de Educação, Curso de Pedagogia, na Universidade Estadual do Paraná (UNESPAR) - Campus Paranaguá. Tem experiência na área de Educação, com ênfase em Gestão Escolar, atuando principalmente nos seguintes temas: formação de professores, educação inclusiva, gestão da educação e política educacional.

\section{Fernanda Borges de Andrade}

Doutora em Educação pela Universidade Federal de Uberlândia. Atualmente é professora do Departamento de Educação da Universidade Federal do Triângulo Mineiro (UFTM). Atuou como Coordenadora de Gestão de Processos Educacionais do PIBID da UFTM. Desenvolve atividades de ensino nos cursos de Licenciatura bem como atividades de extensão e pesquisa com foco nos seguintes temas: ensino, educação, escola cidadã, formação continuada e autonomia do professor.

\section{Jacqueline Oliveira Lima Zago}

Mestre em Educação pela Universidade Federal de Uberlândia. Doutoranda do Programa de Pós-Graduação da Universidade Federal de Uberlândia. Atualmente é Pedagoga da Universidade Federal do Triângulo Mineiro (UFTM). Pesquisa e tem experiência profissional na área de Políticas Públicas, com ênfase em Política Educacional, atuando principalmente nos seguintes temas: Trabalho e Educação, Educação Superior, Educação Profissional e Projeto Pedagógico.

\section{José Carlos de Melo}

Doutor em Educação pela Pontifícia Universidade Católica de São Paulo. Pós-doutor pela Universidade Católica de Santos. Atualmente é professor adjunto na Universidade Federal do Maranhão (UFMA). Coordenador do Grupo de Estudos e Pesquisas em Educação Infância \& Docência - GEPEID. Atua nas áreas de Educação, com ênfase em Educação, atuando principalmente nos seguintes temas: Educação, 
Educação Infantil, Psicologia da Educação, Currículo, Docência no Ensino Superior, Educação Ambiental e Prática Docente.

\section{Leociléa Aparecida Vieira}

Doutora em Educação pela Pontifícia Universidade Católica de São Paulo. Atualmente é professora adjunta do curso de Pedagogia da Universidade Estadual do Paraná (UNESPAR) - Campus Paranaguá. Tem experiência na área de Educação, atuando principalmente nos seguintes temas: formação de professores, estágio supervisionado, prática pedagógica, tecnologia educacional e educação à distância.

\section{Leonice Matilde Richter}

Doutora em Educação pela Universidade Federal de Uberlândia. Atualmente é professora associada na Universidade Federal de Uberlândia (UFU) - Campus Pontal. Atua como coordenadora no Subprojeto Pedagogia/ Pontal do PIBID/UFU com foco na Gestão Escolar. Participa do Grupo de Estudos e Pesquisa em Avaliação (GEPAE) e do Grupo de Estudos e Pesquisas em Políticas, Educação e Cidadania (Pólis). Tem experiência na área de Educação com ênfase nos seguintes temas: políticas de avaliação sistêmica; avaliação da aprendizagem; trabalho docente; educação infantil.

\section{Lusinilda Carla Pinto Martins}

Doutora em Educação Escolar pela Universidade Estadual Paulista Júlio de Mesquita Filho. Atualmente é professora associada da Universidade Federal de Rondônia (UNIR). Tem experiência na área de Letras, com ênfase em Letras, atuando principalmente nos seguintes temas: subjetividade, identidade, discurso, letramento, formação de professores, ensino de línguas estrangeiras.

\section{Maria Célia Borges}

Doutora em Educação pela Pontifícia Universidade Católica de São Paulo. Pós-doutora em Educação pela FEUSP. Atualmente é professora associada na Universidade Federal de Uberlândia (UFU) - Campus 
Pontal. Tem experiência na área de Educação, com ênfase em Formação de professores, Didática e Metodologia do Trabalho Científico, Políticas Educacionais, Gestão Democrática; Educação Superior; Qualidade de Ensino e Inclusão Educacional e Social. Docente permanente no Programa de Pós-Graduação em Educação (Mestrado em Educação) da Universidade Federal do Triângulo Mineiro (UFTM). Docente Permanente no Programa de Pós-graduação (Mestrado em Educação) da Universidade de Uberlândia (UFU).

\section{Miguel Nenevé}

Doutor em Letras (Inglês e Literaturas Correspondentes) pela Universidade Federal de Santa Catarina (1996). Pós-doutorado na York University, Canadá, e pós-doutorado na University of Guyana, Georgetown. Atualmente é professor titular na Universidade Federal de Rondônia (UNIR). Pesquisador CNPq, nível 2. É líder do grupo de pesquisa do CNPq Literatura, Educação e Cultura: Caminhos da Alteridade. Desenvolve pesquisa nos seguintes temas: literatura canadense, literatura na Amazônia, discurso, educação, pós-colonialismo. Tem publicações em livros e revistas especializadas, no Brasil e no exterior, na área de tradução, literatura pós-colonial, literatura de viagem sobre a Amazônia e literatura canadense.

\section{Neide Borges Pedrosa}

Doutora em Educação pela Pontifícia Universidade Católica de São Paulo. Atualmente é professora adjunta da Universidade Federal de Rondônia (UNIR). Coordenadora do Labmídia. Membro do Grupo de Pesquisa Multidisciplinar em Educação e Infância - EDUCA, coordenando a linha de pesquisa: Práticas pedagógicas, inovações curriculares e tecnológicas. Desenvolve atividades de ensino, extensão e pesquisa, com foco nos seguintes temas: tecnologias e educação; educação e relações étnico-raciais.

\section{Rafael Fonseca de Castro}

Doutor em Educação pela Universidade Federal de Pelotas. Atualmente é professor na Universidade Federal de Rondônia (UNIR). Desenvolve 
estudos sobre ensino e aprendizagem, formação de professores, Psicologia da Educação, metodologia de pesquisa, Tecnologias Emergentes e EaD, Gestão Escolar, Linguística Textual e Educação na Saúde. Professor permanente no Mestrado Acadêmico em Educação (MEDUC/UNIR). É líder do Grupo de pesquisa Educação, Psicologia Educacional e Processos Formativos, cujas linhas de pesquisa são Pesquisas Intervenção, Teoria Histórico-Cultural da Atividade e Produção de Saberes e a Formação Continuada de Professores.

\section{Rogéria Moreira Rezende Isobe}

Doutora em Educação pela Pontifícia Universidade Católica de São Paulo. Atualmente é professora associada do Departamento de Educação da Universidade Federal do Triângulo Mineiro (UFTM). Desenvolve atividades de ensino nos cursos de Licenciatura bem como atividades de extensão e pesquisa, com foco nos seguintes temas: História da educação e Políticas educacionais, voltadas para o trabalho docente, reconhecendo o caráter essencialmente histórico dos processos que envolvem a temática.

\section{Terezinha Fernandes Martins de Souza}

Doutora em Educação pela Universidade Federal de Santa Catarina, com doutoramento sanduíche na Universidade Aberta de Portugal. Atualmente é professora da Universidade Federal de Mato Grosso (UFTM), Instituto de Educação, Departamento de Ensino e Organização Escolar/Educação a Distância e Programa de Pós-graduação em Educação (PPGE). Membro dos Grupos de Pesquisa Lêtece/UFMT; Edumídias/ UFSC e Gpdoc/UERJ.

\section{Valdeniza Maria Lopes da Barra}

Doutora em Educação pela Pontifícia Universidade Católica de São Paulo. Atualmente é professora associada da Faculdade de Educação da Universidade Federal de Goiás (UFG), com atuação na graduação e no Programa de Pós-Graduação em Educação. 


\section{Valéria Moreira Rezende}

Doutora em Educação pela Pontifícia Universidade Católica de São Paulo. Atualmente é professora associada e pesquisadora do Curso de Pedagogia da Universidade Federal de Uberlândia (UFU) - Campus Pontal. Líder do Grupo de Estudos e Pesquisas em Política, Formação Docente e Práticas Educativas - GEPPOPE. Desenvolve pesquisas em Políticas Educacionais com ênfase nos seguintes temas: Planejamento e Práticas Educativas, Formação/Trabalho Docente e Currículo e o Trabalho Pedagógico. 

